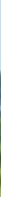

W.

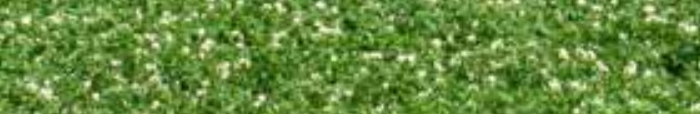

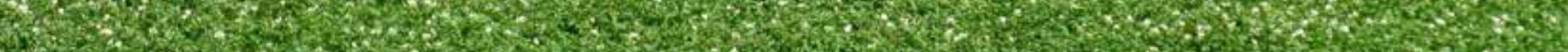

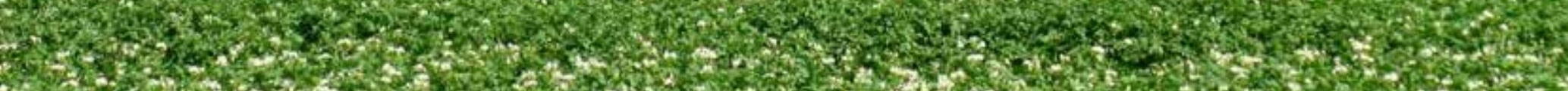

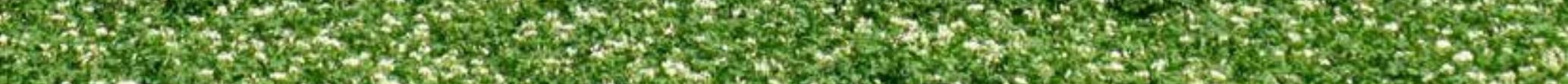

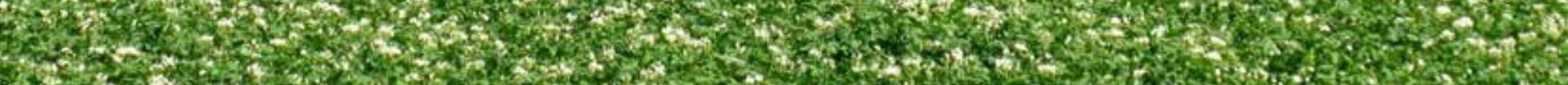

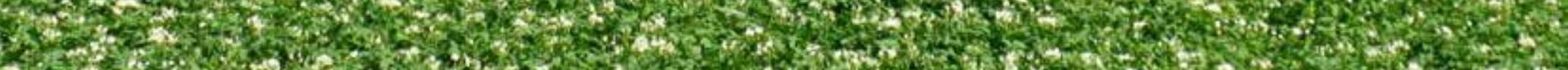

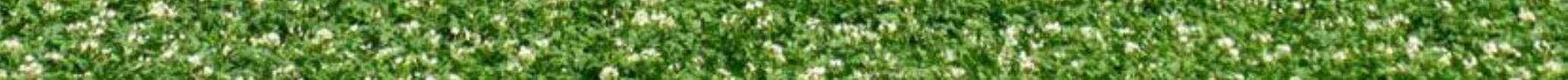

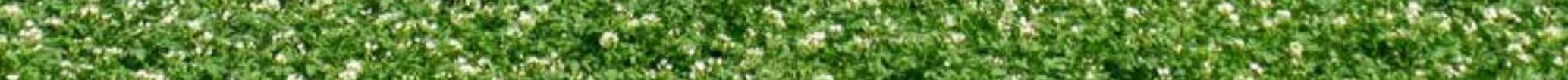

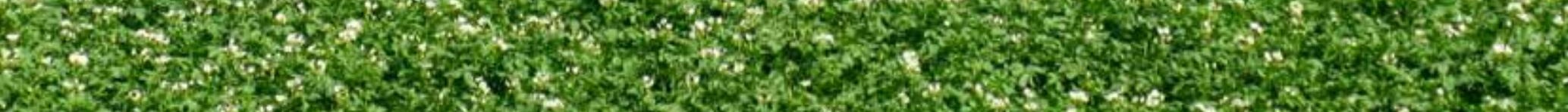

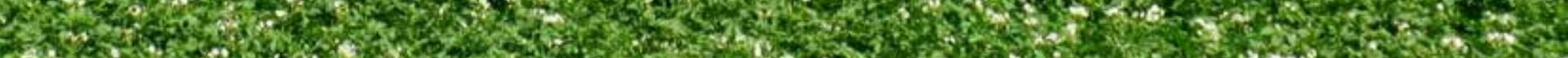

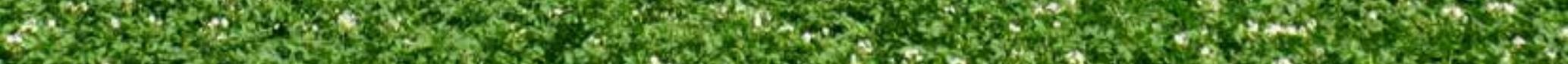

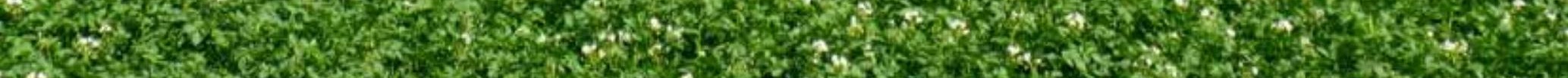

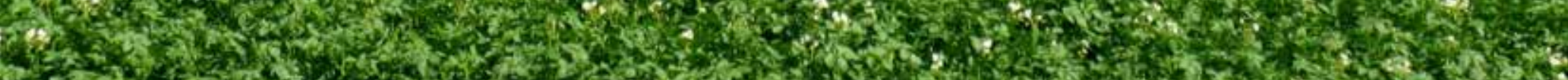

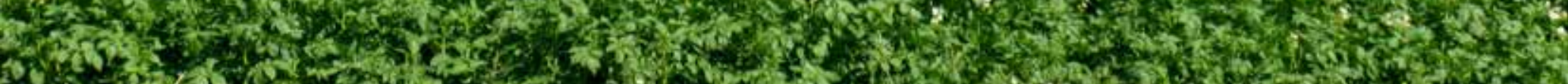
13.

\title{
Barometer duurzame landbouw Zuid-Holland
}

Trends en ontwikkelingen in de akkerbouw en melkveehouderij

Mark Dolman, Jakob Jager en Ruud van der Meer

WAGENINGEN

UNIVERSITY \& RESEARCH 



\section{Barometer duurzame landbouw Zuid-Holland}

Trends en ontwikkelingen in de akkerbouw en melkveehouderij

Mark Dolman, Jakob Jager en Ruud van der Meer

Dit onderzoek is uitgevoerd door Wageningen Economic Research in opdracht van en gefinancierd door de Provincie Zuid-Holland.

Wageningen Economic Research

Wageningen, mei 2017

NOTA

2017-052 
Dolman, Mark, Jakob Jager en Ruud van der Meer, 2017. Barometer duurzame landbouw ZuidHolland; Trends en ontwikkelingen in de akkerbouw en melkveehouderij. Wageningen, Wageningen Economic Research, Nota 2017-052. 67 blz.; 80 fig.; 3 tab.; 13 ref.

De Barometer gaat over de duurzaamheidsprestaties van de grondgebonden landbouw in Zuid-Holland en omvat een groot aantal indicatoren op people-, planet- en profit-thema's. Het gemiddelde akkerbouwbedrijf is beter gaan presteren op het gebied van fosfaatbenutting, milieubelastingspunten per hectare, inkomen uit bedrijf en areaal duurzame teelt. Op het gebied van stikstofoverschot en energie-efficiëntie zijn bedrijven minder duurzaam geworden. Het gemiddelde melkveebedrijf is beter gaan presteren op het gebied van stikstofoverschot per hectare en energie-efficiëntie. Daar stond tegenover dat het inkomen en het aandeel bedrijven dat huisverkoop toepaste afnam.

Trefwoorden: Duurzame landbouw, Zuid-Holland, Akkerbouw, Melkveehouderij, Barometer

Deze nota is gratis te downloaden op http://dx.doi.org/10.18174/414177 of op www. wur. nl/economicresearch (onder Wageningen Economic Research publicaties).

(C) 2017 Wageningen Economic Research

Postbus 29703, 2502 LS Den Haag, T 07033583 30, E communications.ssg@wur.nl, www. wur.nl/economic-research. Wageningen Economic Research is onderdeel van Wageningen University \& Research.

\section{(cc) BY-NC}

Wageningen Economic Research hanteert voor haar rapporten een Creative Commons Naamsvermelding 3.0 Nederland licentie.

(C) Wageningen Economic Research, onderdeel van Stichting Wageningen Research, 2017 De gebruiker mag het werk kopiëren, verspreiden en doorgeven en afgeleide werken maken. Materiaal van derden waarvan in het werk gebruik is gemaakt en waarop intellectuele eigendomsrechten berusten, mogen niet zonder voorafgaande toestemming van derden gebruikt worden. De gebruiker dient bij het werk de door de maker of de licentiegever aangegeven naam te vermelden, maar niet zodanig dat de indruk gewekt wordt dat zij daarmee instemmen met het werk van de gebruiker of het gebruik van het werk. De gebruiker mag het werk niet voor commerciële doeleinden gebruiken.

Wageningen Economic Research aanvaardt geen aansprakelijkheid voor eventuele schade voortvloeiend uit het gebruik van de resultaten van dit onderzoek of de toepassing van de adviezen.

Wageningen Economic Research is ISO 9001:2008 gecertificeerd.

Wageningen Economic Research Rapport 2017-052 | Projectcode 228200271

Foto omslag: Shutterstock 


\section{Inhoud}

$\begin{array}{ll}\text { Woord vooraf } & 6\end{array}$

$\begin{array}{ll}\text { Samenvatting } & 7\end{array}$

1

$\begin{array}{ll}\text { Inleiding } & 9\end{array}$

1.1 Van ambities naar effectmeting 9

$\begin{array}{lll}1.2 & \text { Focus op het primaire akkerbouw- en melkveebedrijf } & 10\end{array}$

$\begin{array}{lll}1.3 & \text { People, planet en profit } & 10\end{array}$

1.4 Selectie van duurzaamheidsindicatoren 11

2

$\begin{array}{ll}\text { Landbouwstructuur } & 13\end{array}$

$\begin{array}{lll}2.1 & \text { Bedrijfsomvang en specialisatiegraad } & 13\end{array}$

$\begin{array}{lll}2.2 & \text { Standaardverdiencapaciteit } & 18\end{array}$

$\begin{array}{lll}2.3 & \text { Areaalverdeling } & 21\end{array}$

$\begin{array}{lll}2.4 & \text { Productiviteit } & 22\end{array}$

$\begin{array}{lll}2.5 & \text { Biologische landbouw } & 27\end{array}$

3

$\begin{array}{ll}\text { People } & \mathbf{3 0}\end{array}$

3.1 Arbeidsinzet 30

$\begin{array}{lll}3.2 & \text { Bedrijfsopvolging } & 32\end{array}$

$\begin{array}{lll}3.3 & \text { Dierenwelzijn- en gezondheid } & 35\end{array}$

$\begin{array}{lll}3.4 & \text { Duurzaam voedsel } & 37\end{array}$

$\begin{array}{llr}4 & \text { Planet } & 38\end{array}$

$\begin{array}{lll}4.1 & \text { Klimaat en energie } & 38\end{array}$

4.2 Mestgebruik en -overschot $\quad 42$

$\begin{array}{lll}4.3 & \text { Gewasbescherming } & 47\end{array}$

$\begin{array}{lll}4.4 & \text { Fijnstof } & 51\end{array}$

4.5 Water $\quad 52$

$\begin{array}{lll}4.6 & \text { Biodiversiteit } & 54\end{array}$

$5 \quad$ Profit $r 5$

5.1 Macro-economie $\quad 55$

5.2 Economisch resultaat $\quad 55$

$\begin{array}{lll}5.3 & \text { Balans en financiering } & 59\end{array}$

6 Barometer duurzame landbouw: samengestelde effectindicator

62

6.1 Barometer akkerbouw $\quad 62$

6.2 Barometer melkveehouderij 64

$\begin{array}{ll}\text { Literatuur en websites } & 66\end{array}$ 



\section{Woord vooraf}

De provincie Zuid-Holland streeft naar een duurzame, sterke en toekomstbestendige grondgebonden landbouw. In 2016 hebben Provinciale Staten besloten een begrotingseffectindicator te ontwikkelen om de verduurzaming van de grondgebonden akkerbouw en melkveehouderij te meten. Wageningen Economic Research is in december 2016 gevraagd een samengestelde indicator te ontwikkelen: Barometer Duurzame Landbouw Zuid-Holland.

Deze Barometer omvat een groot aantal indicatoren op people-, planet- en profit-thema's. De Barometer beoogt de afzonderlijke thema's in samenhang en zo kwantitatief mogelijk te presenteren en voortgang van de volgende provinciale beleidsdoelen te meten: het verbeteren van de kwaliteit van de leefomgeving via verduurzaming door het sluiten van grondstofkringlopen, het versterken van regionale voedselketens en het versterken van de biodiversiteit bij normale agrarische bedrijfsvoering door nieuwe verdienmodellen. Daarnaast wil de provincie een sterk economisch cluster op lange termijn in stand houden.

Wageningen Economic Research bedankt het kernteam Duurzame Landbouw van de provincie ZuidHolland (Jaap Halbersma, Hans Koot en Lucas Mutsaers) voor de prettige communicatie, betrokkenheid en doelgerichtheid. Een speciaal dankwoord is op z'n plaats voor die leden van Provinciale Staten die voor dit project input leverden tijdens een workshop waarin een conceptlijst van indicatoren is besproken.

Verder bedanken wij Herman Docters van Leeuwen van Stichting Milieukeur (SMK) voor het aanleveren van data voor de indicatoren integraal duurzame stallen en duurzaam teeltareaal én het meedenken over het samenstellen van de indicatorenset en het reviewen van deze rapportage.

Namens Wageningen Economic Research is dit onderzoek uitgevoerd door Mark Dolman ( projectleider), Ruud van der Meer (specialist duurzaamheid akkerbouw), Jakob Jager (specialist duurzaamheid melkveehouderij), Walter van Everdingen en Wietse Dol (dataspecialisten).

Prof.dr.ir. J.G.A.J. (J ack) van der Vorst Algemeen Directeur Social Sciences Group (SSG) Wageningen University \& Research 


\section{Samenvatting}

De Barometer gaat over de duurzaamheidsprestaties van de grondgebonden landbouw in Zuid-Holland en omvat een groot aantal indicatoren op people-, planet- en profit-thema's. De Barometer beoogt de afzonderlijke thema's in samenhang en zo kwantitatief mogelijk te presenteren en vooruitgang van de volgende provinciale beleidsdoelen te meten: het verbeteren kwaliteit van de leefomgeving via verduurzaming door het sluiten van grondstofkringlopen, het versterken van regionale voedselketens en het versterken van de biodiversiteit bij normale agrarische bedrijfsvoering door nieuwe verdienmodellen. Daarnaast wil de provincie een sterk economisch cluster op lange termijn in stand houden.

\section{Akkerbouw}

De Barometer duurzame akkerbouw Zuid-Holland laat zien dat de verschillen in duurzaamheidsprestaties van het jaar 2015 ten opzichte van de referentie, het meerjaarsgemiddelde (2010-2015), op de meeste indicatoren klein zijn (figuur S1). Het gemiddelde akkerbouwbedrijf in Zuid-Holland is beter gaan presteren op het gebied van fosfaatbenutting, milieubelastingspunten per ha, inkomen uit bedrijf en areaal duurzame teelt (groene vlakken in de figuur). Op het gebied van stikstofoverschot en energie- efficiëntie zijn bedrijven minder duurzaam (rode vlakken in de figuur) geworden.

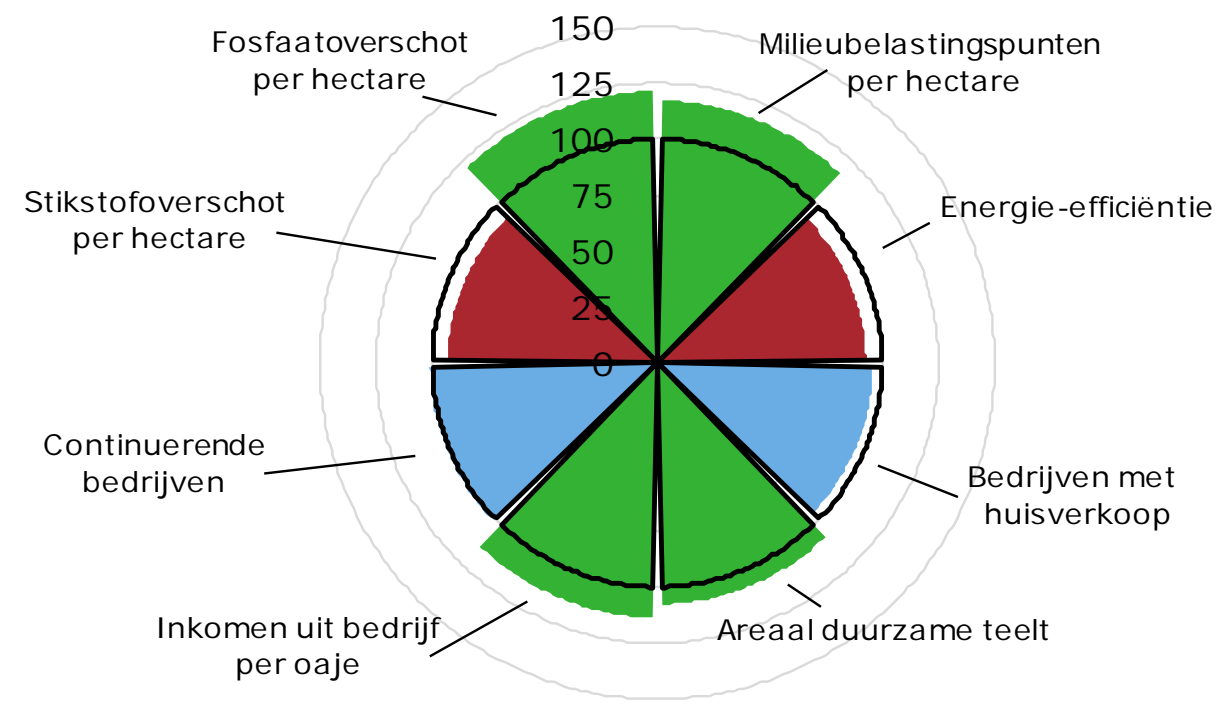

Figuur S1 Genormaliseerde relatieve duurzaamheidsprestaties a) in 2015 (vlakken) ten opzichte van het meerjaarsgemiddelde (2010-2015) (dikke lijn) op akkerbouwbedrijven in Zuid-Holland a) Een score van 150 betekent dat de bedrijven in 2015 50\% duurzamer presteren dan het meerjaarsgemiddelde. Het meerjaarsgemiddelde is hierbij op 100 gesteld.

Bron: Wageningen Economic Research.

Het fosfaatoverschot per hectare cultuurgrond nam in 2015 met $21 \%$ af ten opzichte van het meerjaarsgemiddelde doordat minder fosfaatkunstmeststoffen zijn gebruikt. De milieubelasting van gewasbescherming per hectare cultuurgrond nam af doordat er maatregelen zijn genomen om het verwaaien van middelen in het oppervlaktewater (drift) te verminderen, zoals andere spuitdoppen, luchtondersteuning en spuitvrije zones. Het inkomen per onbetaalde arbeidsjaareenheid in 2015 lag iets boven het meerjaarsgemiddelde, waarbij 2011 en 2014 hele matige jaren en 2010 en 2012 hele goede jaren waren. Daarnaast moet opgemerkt worden dat de inkomensverschillen tussen bedrijven groot zijn. Deze verschillen worden veroorzaakt door verschil in ondernemerschap, maar ook in bouwplannen, 
productie per hectare, kwaliteit van de gewassen en het tijdstip en de wijze van de afzet. Het stikstofbodemoverschot per hectare cultuurgrond nam in 2015 met $7 \%$ toe ten opzichte van het meerjaarsgemiddelde, met name door een stijging van het stikstofkunstmestgebruik. Het energiegebruik per hectare cultuurgrond nam ook iets toe. Tussen de jaren fluctueert het energiegebruik onder andere door verschillen in bodemomstandigheden tijdens de teeltwerkzaamheden of de weersomstandigheden waardoor de frequentie van beregening of het uitvoeren van gewasbescherming verschilt. Het aandeel bedrijven dat een opvolger heeft en het aandeel bedrijven dat huisverkoop toepast in 2015 , is gelijk aan het meerjaarsgemiddelde (blauwe vlakken in de figuur).

\section{Melkveehouderij}

De Barometer duurzame melkveehouderij Zuid-Holland laat zien dat de verschillen in duurzaamheidsprestaties van het jaar 2015 ten opzichte van het meerjaarsgemiddelde (2010-2015) op de meeste indicatoren klein zijn (figuur S2). Het gemiddelde melkveebedrijf is in Zuid-Holland beter gaan presteren op het gebied van stikstofoverschot per hectare en energie-efficiëntie. Daar stond tegenover dat het inkomen en het aandeel bedrijven dat huisverkoop toepaste afnam.

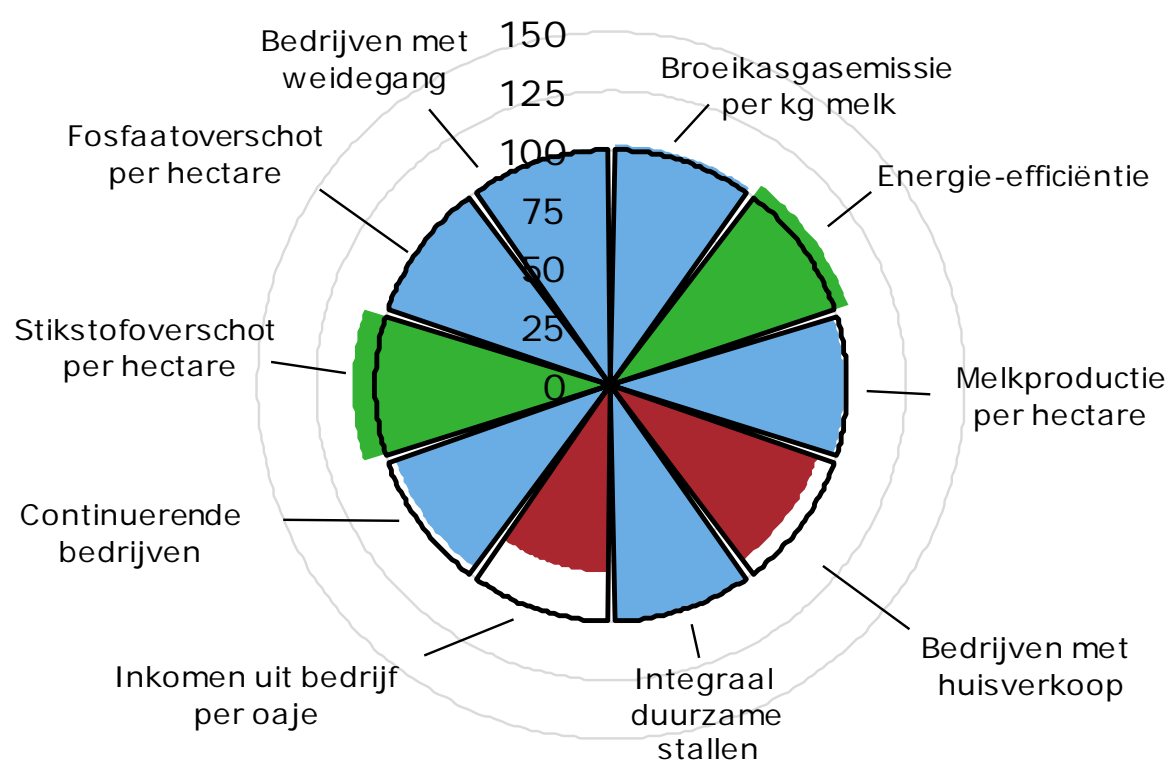

Figuur 52 Genormaliseerde relatieve duurzaamheidsprestaties a) van Zuid-Hollandse melkveebedrijven (vlakken) ten opzichte van het Nederlands gemiddelde (dikke lijn) in 2015 a) Een score van 150 betekent dat de bedrijven in 2015 50\% duurzamer presteren dan het meerjaarsgemiddelde. Het meerjaarsgemiddelde is hierbij op 100 gesteld.

Bron: Wageningen Economic Research.

Het stikstofoverschot per hectare cultuurgrond op melkveebedrijven in Zuid-Holland nam in 2015 met bijna $10 \%$ af ten opzichte van het meerjaarsgemiddelde. De iets toegenomen melkproductie per hectare voederoppervlakte leidt tot een hogere productie van stikstof en fosfaat in mest per ha. Dit leidde, samen met aanscherpingen in gebruiksnormen, tot een toename in de afvoer van mest en daardoor tot een afname van het zowel het stikstof- als fosfaatoverschot. Het energiegebruik per kg melk verbeterde in 2015 ten opzichte van het meerjaarsgemiddelde. Het energiegebruik op melkveebedrijven in ZuidHolland daalde in 2015 voor het vijfde jaar op rij. De daling in energiegebruik per ton melk vond plaats bij zowel het diesel- als elektriciteitsverbruik. Het inkomen uit bedrijf per onbetaalde arbeidsjaareenheid was in 2015 lager dan het meerjaarsgemiddelde. Dit wordt met name veroorzaakt doordat er drie bovengemiddelde tot goede jaren (2011, 2013 en 2014) in het meerjaarsgemiddelde zitten. Daarnaast moet opgemerkt worden dat de inkomensverschillen tussen bedrijven groot zijn.

Het aandeel melkveebedrijven dat huisverkoop toepast, nam iets af. Sinds 2007 neemt het aandeel bedrijven dat huisverkoop toepast af. Een mogelijke verklaring zou de toenemende schaalvergroting en specialisatie kunnen zijn. De overige indicatoren zijn gelijk aan het meerjaarsgemiddelde. 


\section{$1 \quad$ Inleiding}

\subsection{Van ambities naar effectmeting}

De provincie Zuid-Holland streeft naar een duurzame, sterke en toekomstbestendige grondgebonden landbouw. In het ambitiedocument van de provincie Zuid-Holland, Samen voor een flinke sprong (2016), is de ambitie benoemd voor een sterke positie van een duurzame en economische rendabele grondgebonden landbouw. Deze ambitie is vertaald naar de volgende doelen:

- verbeteren kwaliteit van de leefomgeving via verduurzaming

- het sluiten van grondstofkringlopen

- het versterken van regionale voedselketens

- het versterken van de biodiversiteit bij normale agrarische bedrijfsvoering door nieuwe verdienmodellen.

- versterken van volhoudbare sterke economische sector

- een sterke economisch cluster op lange termijn in stand houden.

In september 2016 heeft Gedeputeerde Staten (GS) van Zuid-Holland een monitorsysteem toegezegd voor duurzame landbouw (grondgebonden akkerbouw en melkveehouderij) voor bovenstaande doelen. De voortgang op deze doelen wordt door de Provincie gemonitord met behulp van prestatieindicatoren en effectindicatoren en verantwoord via de begrotingssystematiek van de provincie.

Wageningen Economic Research is gevraagd om voor het onderdeel effectmeting een samengestelde indicator te ontwikkelen: Barometer Duurzame Landbouw Zuid-Holland. Deze Barometer omvat een groot aantal indicatoren op people, planet en profit-thema's. De Barometer beoogt de afzonderlijke thema's in samenhang en zo kwantitatief mogelijk te presenteren voor zowel de akkerbouw als melkveehouderij. De Barometer wordt ontwikkeld als begrotingsindicator. De Barometer (figuur 1.1) bestaat uit drie onderdelen:

- een analyse van trends en ontwikkelingen op het gebied van duurzaamheidsthema's op basis van set van indicatoren (deze nota)

- een samengestelde effectindicator bestaande uit de belangrijkste duurzaamheidsindicatoren inclusief een beknopte analyse (factsheet)

- een grafische weergave van de belangrijkste duurzaamheidsindicatoren (infographic).

In overleg met de provincie Zuid-Holland is besloten om de Barometer in eerste instantie te ontwikkelen voor de grondgebonden landbouw (akkerbouw en melkveehouderij) in Zuid-Holland, omdat een groot deel van de economische waarde en het landschap in Zuid-Holland wordt bepaald door de akkerbouw en de melkveehouderij (Vogelzang et al., 2016). ${ }^{1}$ Daarnaast zijn voor deze sectoren veel data beschikbaar om een zo veel mogelijk kwantitatieve invulling te geven aan de Barometer.

In principe kan op alle niveaus gemeten worden, maar niet op elk niveau kunnen prestaties daadwerkelijk worden beïnvloed door de provincie of stakeholders in de provincie. Bij de meeste duurzaamheidproblemen heeft de primaire schakel (het boerenbedrijf) de grootste impact. Een groot deel van de duurzaamheidsimpact vindt plaats op het boerenbedrijf, of wordt in belangrijke mate beïnvloed door keuzes die gemaakt worden in de primaire schakel. Bij het meten van duurzaamheid hangen veel factoren met elkaar samen en zou daarom op een zo hoog mogelijk schaalniveau gemeten moeten worden. De uitvoerbaarheid is daarbij echter traag en complex en de data zijn lastig herleidbaar tot genomen maatregelen. Dit betekent dus dat bij de ontwikkeling van deze Barometer gezocht is naar een balans tussen enerzijds het zo scherp mogelijk afbakenen van het systeem om de Barometer behapbaar te houden voor de provincie Zuid-Holland en anderzijds zo veel mogelijk

\footnotetext{
1 In dit rapport wordt nader ingegaan op de economische betekenis van de grondgebonden landbouw in Zuid-Holland.
} 
belangrijke externe en/of doorwerkingseffecten van buiten de provincie mee te nemen. Verder is het van belang op het niveau te meten waar betrouwbare gegevens beschikbaar zijn tegen redelijke verzamelkosten. Dit criterium is eveneens meegenomen bij de ontwikkeling van deze Barometer. Op basis van bovenstaande criteria is daarom gefocust op het primaire bedrijf als schaalniveau.

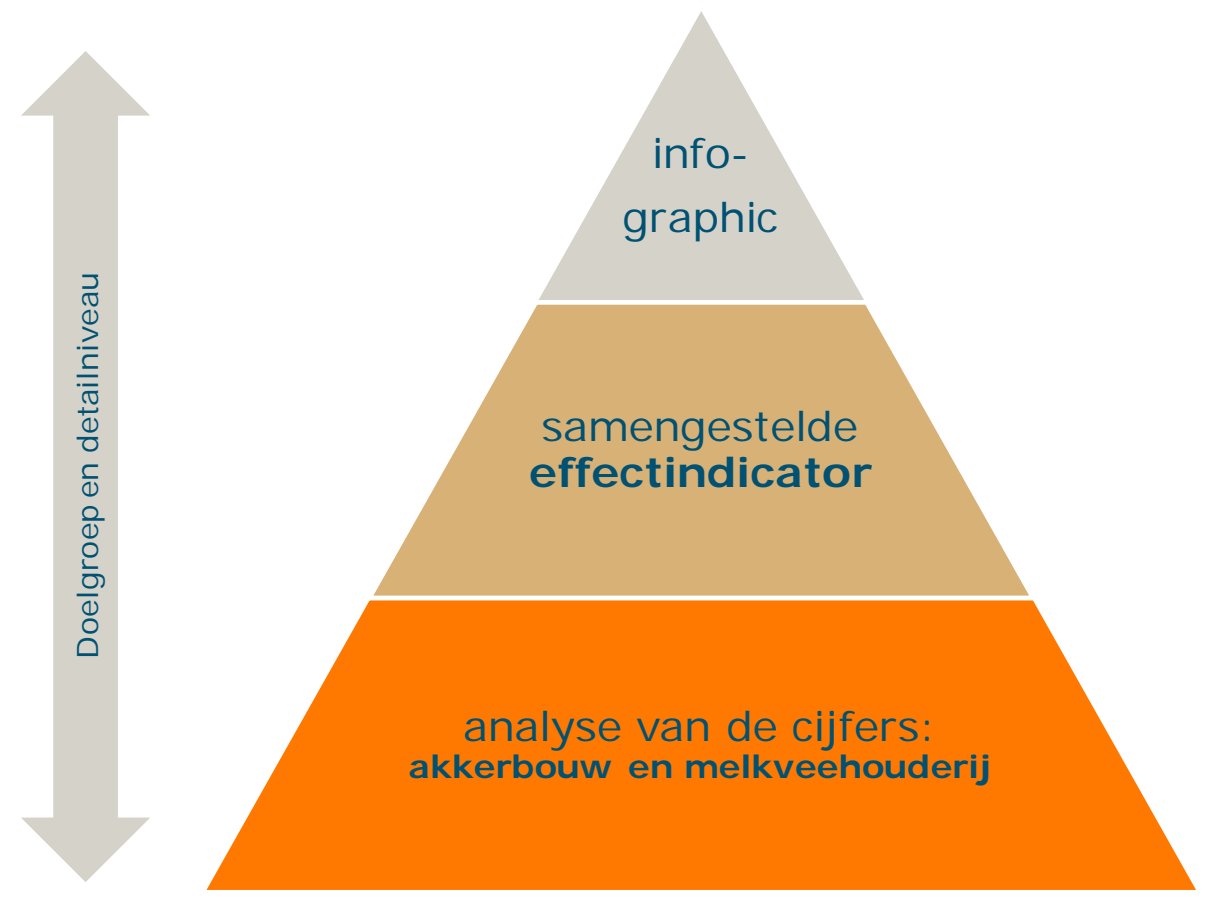

Figuur 1.1 Drie producten van de Barometer Duurzame Landbouw in Zuid-Holland

\subsection{Focus op het primaire akkerbouw- en melkveebedrijf}

Duurzaamheidsprestaties kunnen op verschillende niveaus gemeten worden: geografisch (wereld, EU, land, regio), organisatie (keten, bedrijf, businessunit, vestiging), sector (food, dierlijk, runderen, zuivel, melk). In de Barometer is ervoor gekozen om zo veel mogelijk de prestaties op sectorniveau (akkerbouw en melkveehouderij) te meten, en te focussen op het primaire bedrijf.

\subsection{People, planet en profit}

Bij het benoemen van de thema's is onder andere gebruik gemaakt van criteria van het Global Reporting I nitiative (GRI). Het GRI ontwikkelt wereldwijde standaarden voor bedrijven/organisaties om te rapporteren over maatschappelijk verantwoord ondernemen. Belangrijke aspecten hierin zijn:

- materialiteit

Het thema moet voldoende van belang zijn voor de totaalbeoordeling van de duurzaamheid. Het gekozen thema moet potentieel het oordeel van de verschillende belanghebbenden over de duurzaamheid van de betreffende sector beïnvloeden.

- dekking belangen stakeholders Alle thema's die belanghebbenden inbrengen en die een bepaalde redelijkheid hebben, moeten vertegenwoordigd worden.

- contextbeschrijving Naast de waarde op de indicatoren zelf dient de context in voldoende mate geschetst te worden die voor een redelijke beoordeling van de scores nodig is.

- compleetheid van thema's de balans tussen thema's op de drie P's (people, planet, profit). 
Op basis van deze aspecten is een groslijst van indicatoren opgesteld van mogelijke indicatoren voor de Barometer Duurzame Landbouw in Zuid-Holland. In deze nota staan indicatoren die inzicht geven in de prestaties van de akkerbouw en melkveehouderij in Zuid-Holland. Een deel van deze indicatoren (zie paragraaf 1.4) komt terug in de uiteindelijke Barometer duurzame landbouw. Er is in deze Barometer gekozen voor een 3P-indeling, omdat dit voor veel stakeholders een herkenbare indeling is en een indeling die veelvuldig wordt gebruikt om duurzaamheidsprestaties overzichtelijk weer te geven.

\subsection{Selectie van duurzaamheidsindicatoren}

Alvorens indicatoren voor de samengestelde effectindicator Barometer duurzame landbouw te kiezen, is een groslijst van indicatoren opgesteld op basis van bestaande (landelijke) meetinitiatieven en databeschikbaarheid (figuur 1.2; tabel 1.1).

Voor het kiezen van de indicatoren voor de Barometer is gebruik gemaakt van de criteria in tabel 1.1.

Tabel 1.1 Criteria voor het kiezen van de meest geschikte indicator

\begin{tabular}{ll}
\hline - Compleet & - Schaalbaar naar andere sectoren \\
\hline - Structureel beschikbaar & - Tijdig \\
\hline - Representatief & - Duidelijk \\
\hline - Kwantitatief & - Link micro (bedrijf) en macro (sector, land, regio) mogelijk \\
\hline - Breed gedragen & - Inzichtelijk qua spreiding \\
\hline - Eenvoudig uitvoerbaar & - Kosteneffectief \\
\hline - Robuust & - Betrouwbaar \\
\hline
\end{tabular}

De prestaties van de indicatoren in figuur 1.2 zijn opgenomen in hoofdstuk 2 tot en met 5 . Een selectie van deze indicatoren is uiteindelijk opgenomen in de Barometer duurzame landbouw (tabel 1.2). Deze indicatoren zijn terug te vinden in hoofdstuk 6 (conclusie) en in de samenvatting van deze nota.

Tabel 1.2 Geselecteerde indicatoren voor de Barometer duurzame landbouw Zuid-Holland

\begin{tabular}{ll} 
Indicator Barometer & Welke sectoren? \\
\hline Inkomen uit bedrijf per onbetaalde aje & Akkerbouw en melkveehouderij \\
\hline Aandeel continuerende bedrijven & Akkerbouw en melkveehouderij \\
\hline Aandeel bedrijven met huisverkoop & Akkerbouw en melkveehouderij \\
\hline Stikstofbodemoverschot per hectare & Akkerbouw en melkveehouderij \\
\hline Fosfaatoverschot per hectare & Akkerbouw en melkveehouderij \\
\hline Energie-efficiëntie & Akkerbouw en melkveehouderij \\
\hline Broeikasgasemissie per kg melk & Melkveehouderij \\
\hline Aandeel bedrijven met weidegang & Melkveehouderij \\
\hline Melkproductie per hectare & Melkveehouderij \\
\hline Aandeel integraal duurzame stallen & Melkveehouderij \\
\hline Aandeel areaal duurzame teelt & Akkerbouw \\
\hline Milieubelastingspunten per hectare & Akkerbouw \\
\hline
\end{tabular}


Maatschappelijk \& beleidsrelevante indicatoren

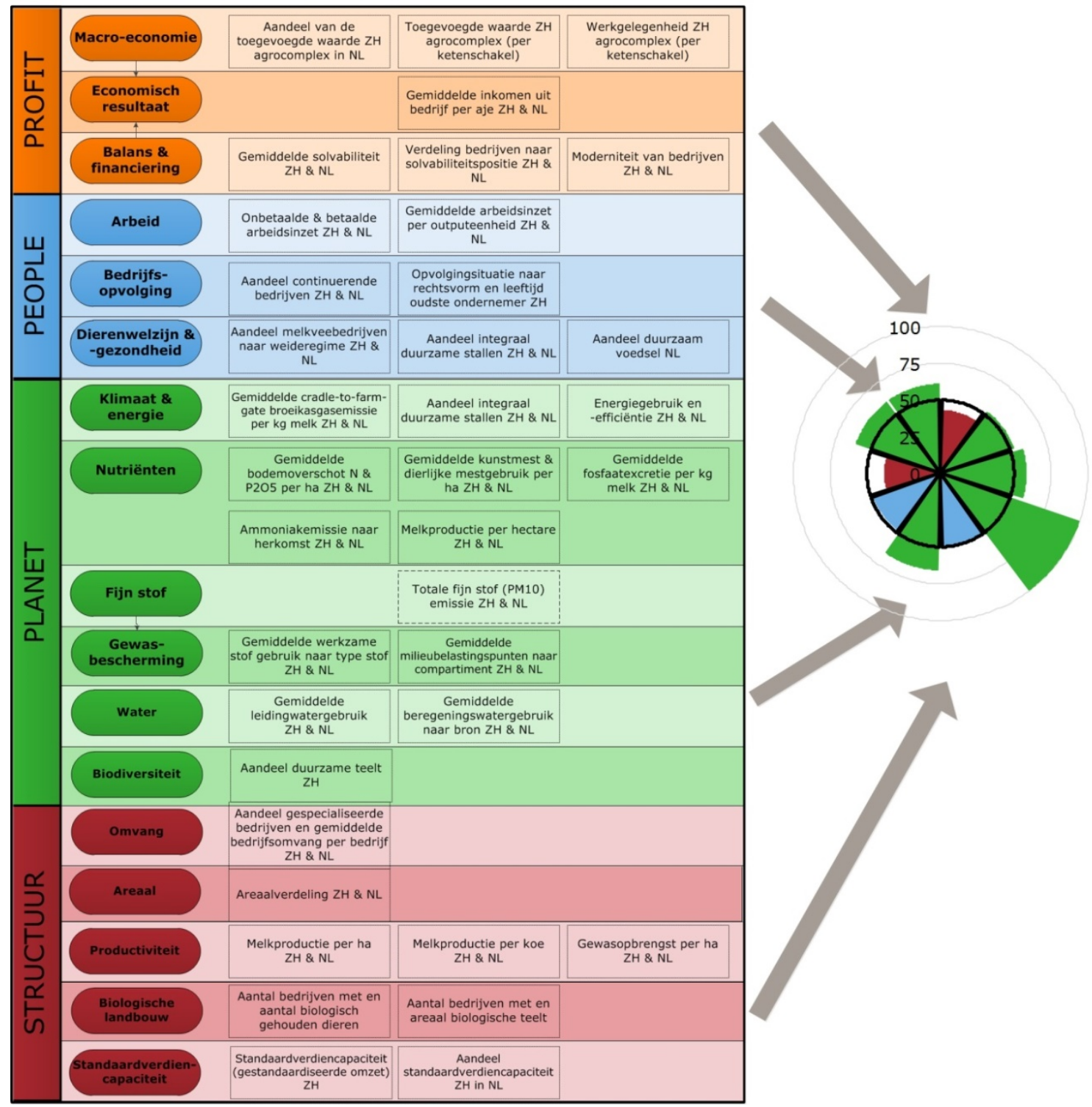

Figuur 1.2 Groslijst van structuur en duurzaamheidsindicatoren waaruit de indicatoren voor de Barometer Duurzame Landbouw zijn gekozen 


\title{
2 Landbouwstructuur
}

Om de voortgang in duurzaamheidsprestaties van de grondgebonden landbouw te meten, is het van belang om inzicht te hebben in algemene structuurontwikkelingen van de meest bepalende sectoren binnen de grondgebonden landbouw in Zuid-Holland: de akkerbouw en melkveehouderij. Het gaat hierbij om zaken als aantallen bedrijven, specialisatiegraad en schaalvergroting. Dat geldt zowel voor de gangbare landbouw, evenals voor de biologische landbouw. De belangrijkste databron voor de landbouwstructuurindicatoren is de CBS Landbouwtelling. Bij die bron gelden enkele belangrijke mijlpalen met wijziging in aanschrijving en samenstelling die de (ontwikkeling van de) resultaten kunnen beïnvloeden. In 2010 is de ondergrens gewijzigd (van 3 Nederlandse grootte-eenheden (nge) naar 3.000 euro Standaardopbrengst (SO)). In 2016 is de aanschrijving van bedrijven gewijzigd en is inschrijving bij Kamer van Koophandel bepalend. Vanaf 2016 zijn daardoor minder bedrijven en minder areaal door de telling gedekt, en zorgt voor een aantal indicatoren voor een trendbreuk tussen 2015 en 2016. De meeste duurzaamheidsindicatoren zijn op basis van het Bedrijveninformatienet, een steekproef van land- en tuinbouwbedrijven ${ }^{2}$. Het laatst beschikbare jaar is daar 2015. Naast het Bedrijveninformatienet zijn voor het vullen van de indicatoren de volgende databronnen gebruikt: Stichting Milieukeur (SMK), Emissieregistratie.nl, en het Landelijk Meetnet effecten Mestbeleid.

\section{$2.1 \quad$ Bedrijfsomvang en specialisatiegraad}

\section{Definitie van gehanteerde indicatoren}

Elk land- en tuinbouwbedrijf wordt ingedeeld in een bedrijfstype, bijvoorbeeld akkerbouwbedrijven, melkveebedrijven, glastuinbouwbedrijven of gemengde bedrijven. Vaak vinden op een bedrijf meerdere agrarische activiteiten plaats. Een deel van de productie vindt plaats op gespecialiseerde bedrijven, terwijl ook een deel plaatsvindt op gemengde bedrijven. De indicator specialisatiegraad geeft aan welk gedeelte van de sectorproductie plaatsvindt op gespecialiseerde bedrijven. De bedrijfsomvang wordt uitgedrukt als het aantal productie-eenheden per bedrijf: hectare cultuurgrond per bedrijf voor akkerbouw en het aantal melk- en kalfkoeien per bedrijf voor de melkveehouderij.

\begin{abstract}
Akkerbouw
Het aantal akkerbouwbedrijven daalde gestaag van 1.000 in 2000 tot ruim 600 in 2016 (figuur 2.1 en 2.2). In de provincie Zuid-Holland werd in 2016 op ruim 35.000 ha akkerbouwgewassen geteeld. Het overgrote deel van dit areaal is te vinden op gespecialiseerde akkerbouwbedrijven (figuur 2.3). De specialisatiegraad bedroeg bijna $80 \%$ in 2016 . Hiermee lag de specialisatiegraad in Zuid-Holland hoger dan gemiddeld in Nederland (figuur 2.4). Sinds het jaar 2000 zijn de akkerbouwbouwbedrijven in Zuid-Holland gegroeid van gemiddeld ongeveer 35 ha tot bijna 50 ha. Ook dit is bovengemiddeld in vergelijking met totaal Nederland. Bedrijven met een groot areaal cultuurgrond zijn vooral te vinden op de Zuid-Hollandse eilanden.
\end{abstract}

\footnotetext{
2 Het Bedrijveninformatienet is een panel van ongeveer 1.500 land- en tuinbouwbedrijven, 100 visserij- en 150 particuliere bosbouwbedrijven. Het panel binnen de land- en tuinbouw representeert de bedrijven uit de CBS-Landbouwtelling die groter zijn dan 25.000 euro Standaardopbrengst. De hele kleine bedrijven worden dus niet gerepresenteerd. De opgenomen land- en tuinbouwbedrijven vertegenwoordigden in 2016 ongeveer $85 \%$ van alle bedrijven uit de Landbouwtelling en ruim 99\% van de totale agrarische productie (gemeten in Standaardopbrengst).
} 


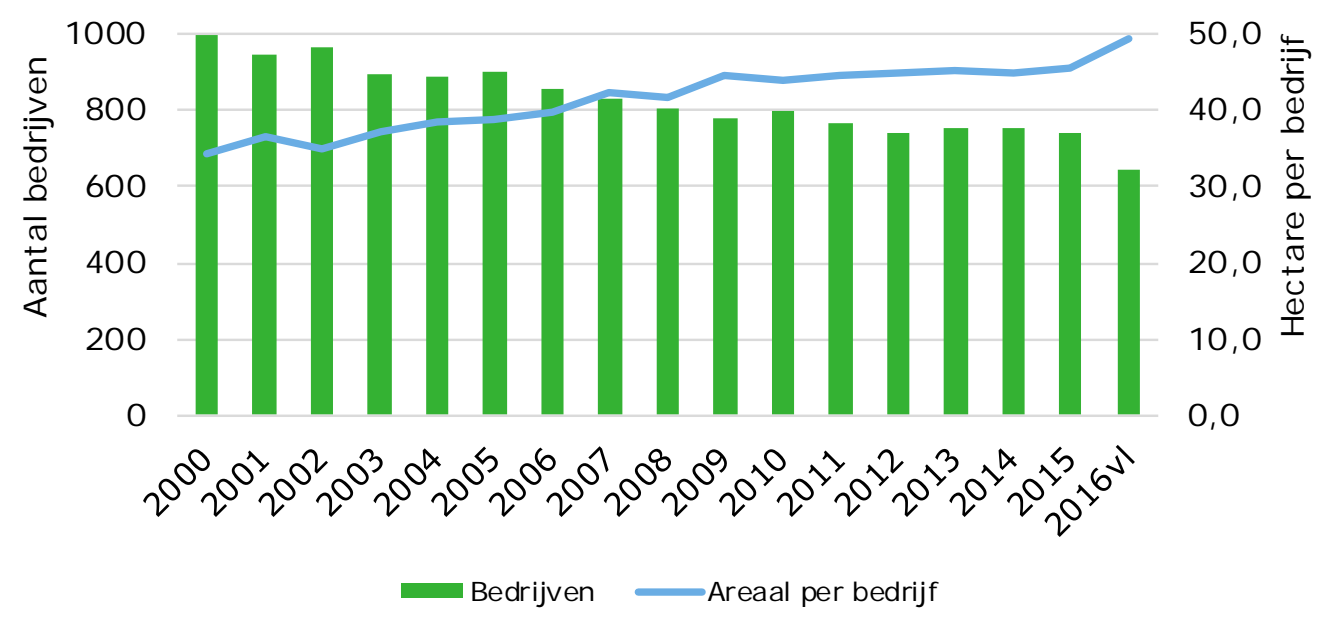

Figuur 2.1 Akkerbouwbedrijven en areaal cultuurgrond per bedrijf in Zuid-Holland Bron: CBS, bewerking Wageningen Economic Research.

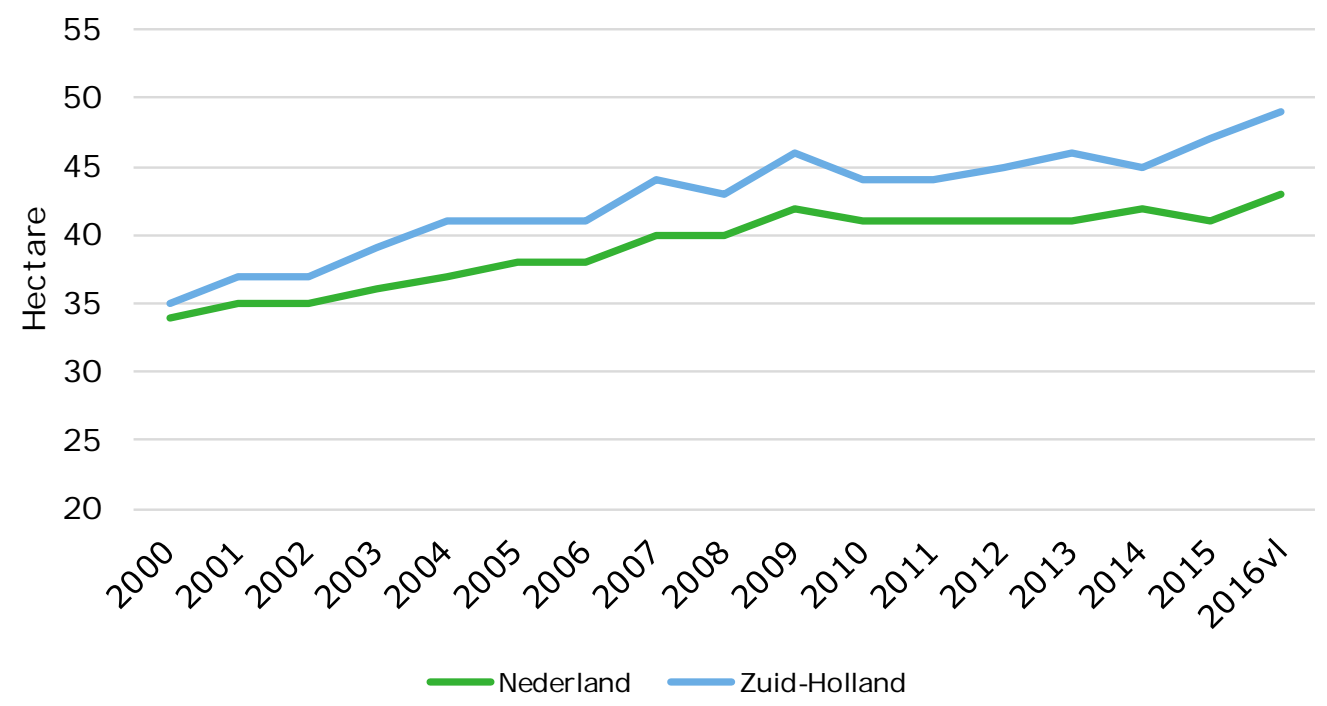

Figuur 2.2 Areaal cultuurgrond per akkerbouwbedrijf Bron: CBS, bewerking Wageningen Economic Research. 


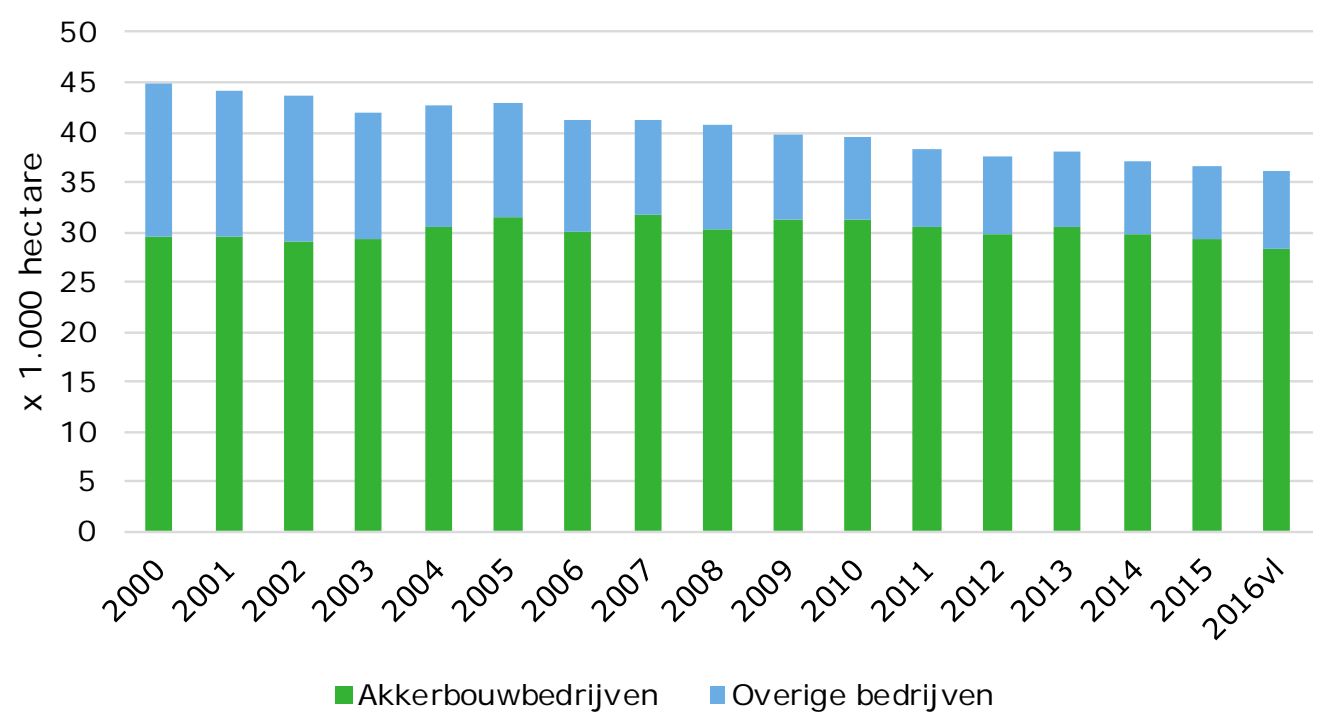

Figuur 2.3 Areaal akkerbouwgewassen op gespecialiseerde akkerbouwbedrijven en overige bedrijven met akkerbouw, in Zuid-Holland

Bron: CBS, bewerking Wageningen Economic Research.

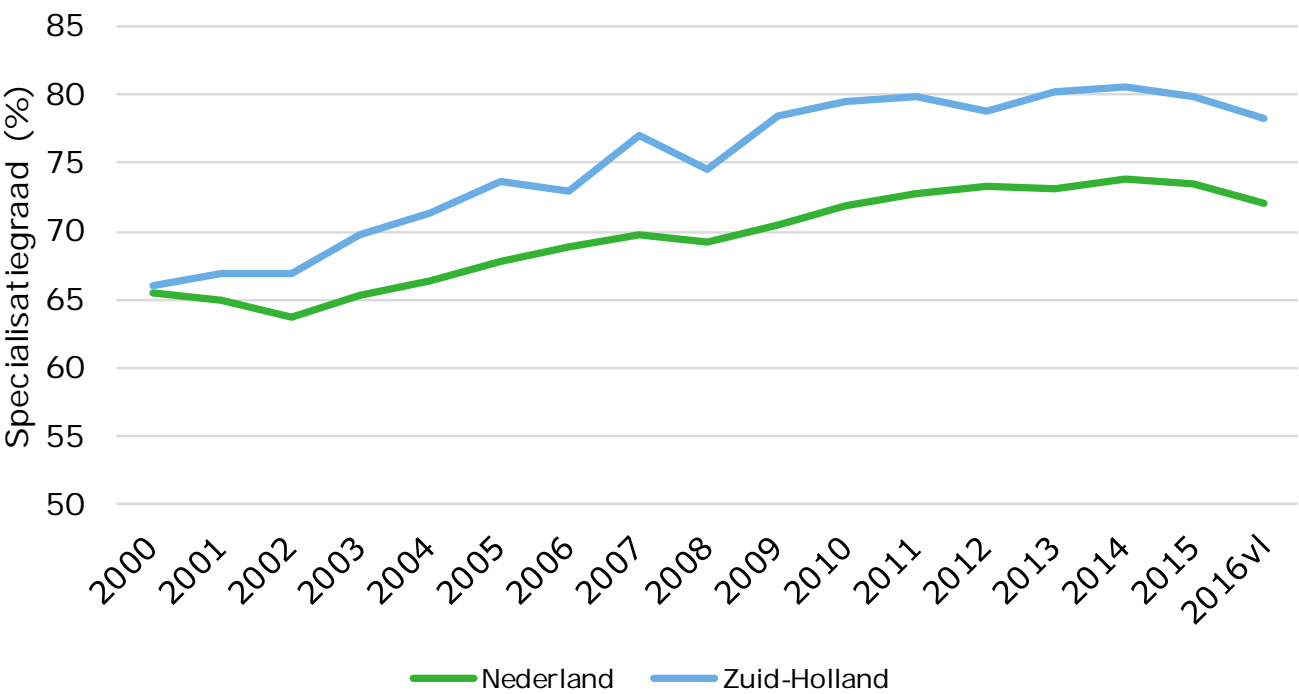

Figuur 2.4 Specialisatiegraad: aandeel van het akkerbouwareaal op gespecialiseerde akkerbouwbedrijven

Bron: CBS, bewerking Wageningen Economic Research.

\section{Melkveehouderij}

Het aantal gespecialiseerde melkveebedrijven in Zuid-Holland is tussen 2000 en 2016 met ruim een derde afgenomen (figuur 2.5). Voor alle melkveebedrijven in Nederland is deze daling iets geringer. De gemiddelde omvang van een Zuid-Hollands melkveebedrijf is in 201687 melkkoeien. Dit is een stijging van twee derde sinds 2000. Dit resulteert in een toename van het aantal melkkoeien op gespecialiseerde bedrijven sinds 2000 van $8 \%$. In Nederland was deze stijging nog groter. De gemiddelde bedrijfsomvang nam toe met ruim 75\%. Het aantal melkkoeien op gespecialiseerde bedrijven nam met een kwart toe. 


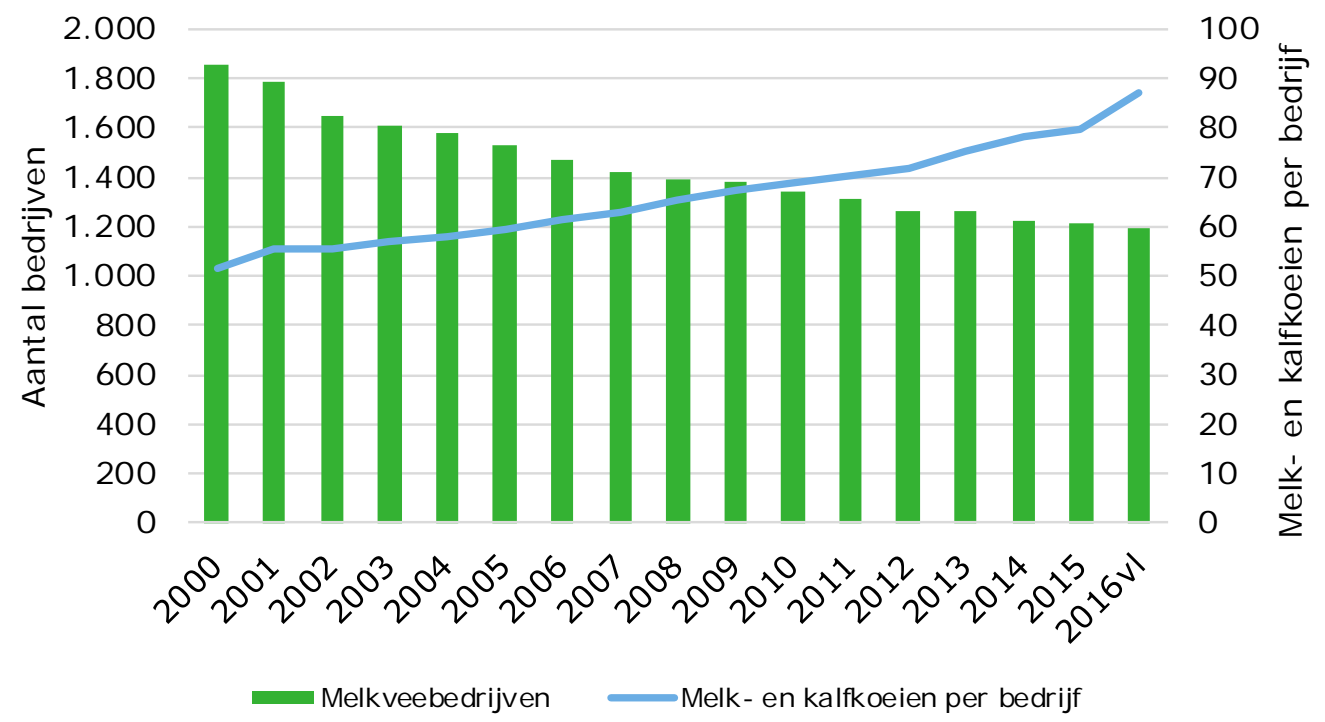

Figuur 2.5 Melkveebedrijven en aantal melk- en kalfkoeien per bedrijf in Zuid-Holland Bron: CBS, bewerking Wageningen Economic Research.

De stijging van de gemiddelde omvang van het gespecialiseerde melkveebedrijf is in Nederland groter dan in Zuid-Holland (figuur 2.6). Een mogelijk verklaring is dat de beschikbaarheid van grond voor de melkveehouderij in Zuid-Holland geringer is. Het aantal melkveebedrijven in Zuid-Holland daalt relatief iets sneller, maar de vrijkomende grond komt blijkbaar niet in bezit van de collega melkveehouder, maar gaat naar andere sectoren naar buiten de landbouw. Dit hangt af van de inkomensverhoudingen tussen de verschillende bedrijfstypen die van invloed is op de prijs die men voor de grond kan betalen. Daarnaast is de concurrentie tussen 'rood' en 'groen' is stevig in ZuidHolland.

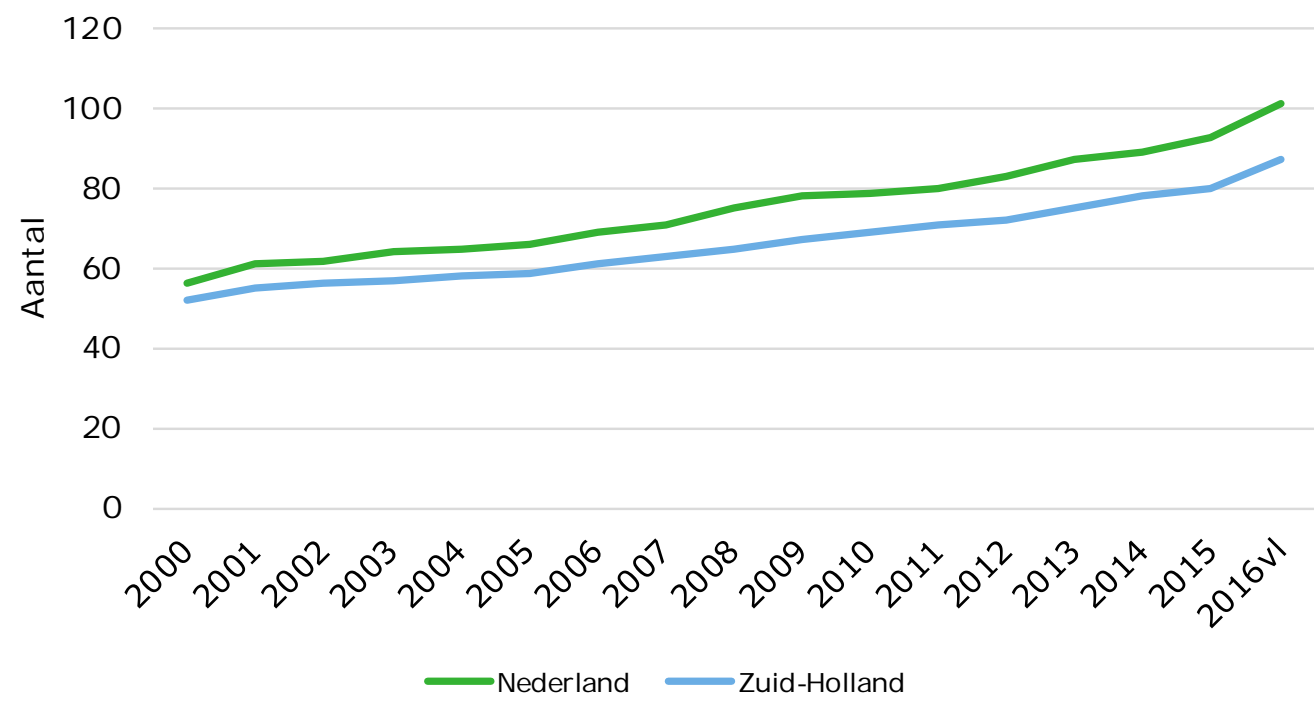

Figuur 2.6 Aantal melk- en kalfkoeien per melkveebedrijf Bron: CBS, bewerking Wageningen Economic Research. 
Op 1 januari 2015 is de 'Wet verantwoorde groei melkveehouderij' van kracht geworden. Deze wet stelt eisen aan de uitbreiding van melkveebedrijven om te borgen dat die uitbreiding in het kader van de Nitraatrichtlijn verantwoord plaatsvindt. Door deze wetgeving wordt de groei van de melkveehouderij gereguleerd, doordat aan de toename van de fosfaatproductie boven de referentie van 2013 de voorwaarde wordt verbonden dat deze of op eigen grond geplaatst wordt of voor $100 \%$ wordt verwerkt, of een combinatie van beide. Daarnaast is per 1 april 2015 een AMvB van kracht geworden die beperkingen stelt aan de groei van bedrijven zonder gronduitbreiding. Intensievere melkveebedrijven die door uitbreiding extra fosfaat produceren, moeten jaarlijks aantonen dat zij over voldoende grond beschikken om ten minste een deel van de extra fosfaat binnen het bedrijf te kunnen gebruiken (Baltussen et al., 2016). Vanaf 1 maart 2017 wordt binnen de kaders van het fosfaatreductieplan van de zuivelsector de melkveestapel stapsgewijs verkleind. Het aantal vrouwelijke runderen moet worden teruggebracht naar het niveau van 2 juli 2015 minus 4\%. Grondgebonden bedrijven zijn uitgezonderd van deze korting van $4 \%$ (RVO, 2017). Het beleidsvoornemen is om per 2018 op basis van een wijziging van de Meststoffenwet een stelsel van fosfaatrechten voor melkvee in te voeren.

De specialisatiegraad van de melkveehouderij in Zuid-Holland neemt toe (figuur 2.7). Het aantal koeien op gespecialiseerde bedrijven is met $8 \%$ toegenomen sinds 2000 , terwijl in totaliteit het aantal koeien maar met circa $4 \%$ is toegenomen.

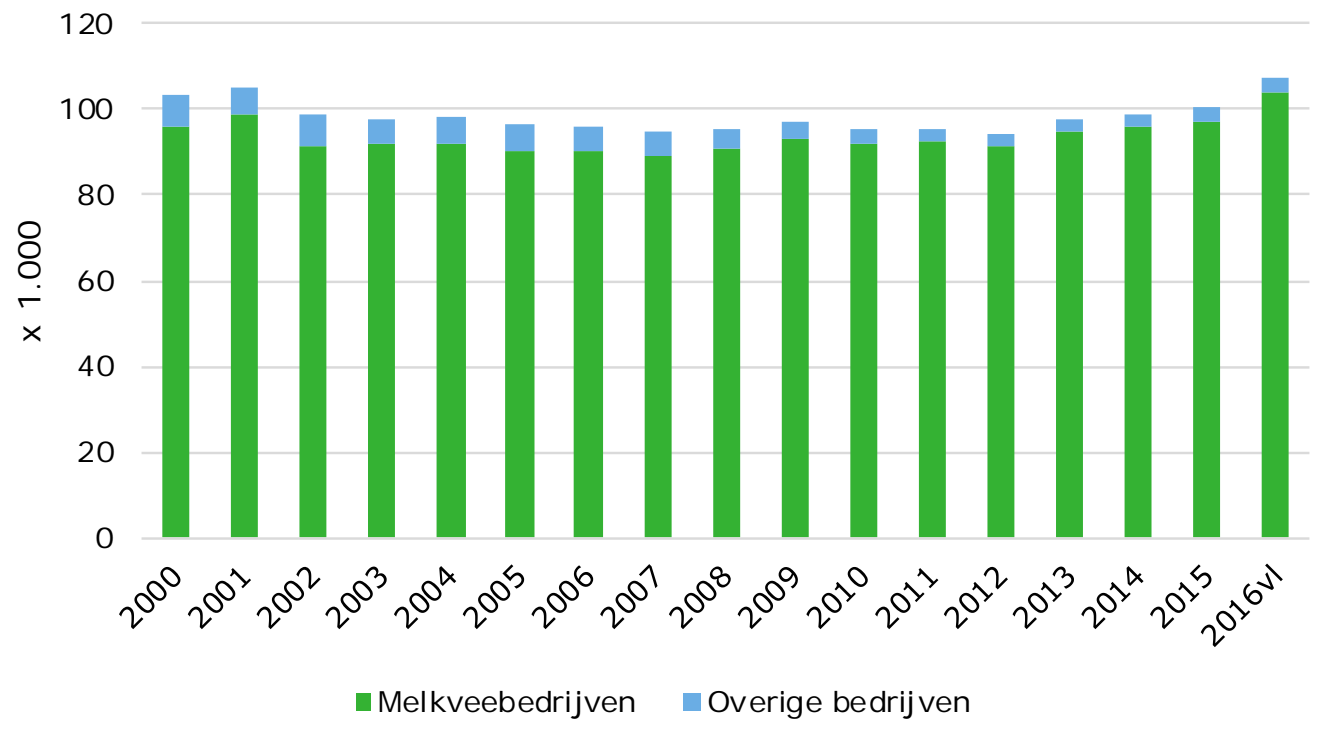

Figuur 2.7 Melk- en kalfkoeien op gespecialiseerde melkveebedrijven en overige bedrijven met melkvee in Zuid-Holland

Bron: CBS, bewerking Wageningen Economic Research.

In vergelijking met Nederland ligt de specialisatiegraad in Zuid-Holland 3\%-punten hoger (figuur 2.8). Het verschil neemt de laatste jaren af van ruim 5\%-punten verschil in het jaar 2000 , tot circa $1 \%$ punt in 2016. Dit heeft waarschijnlijk deels te maken met een verschuiving van bedrijfstypen. Dat gebeurt bijvoorbeeld als een melkveebedrijf de melkkoeien afstoot, maar het bedrijf nog wel voortzet met de teelt van gras en voedergewassen. Het bedrijf wordt dan niet meer als melkveebedrijf getypeerd. Over het algemeen kan gesteld worden dat in de melkveehouderij de specialisatiegraad hoog is. 


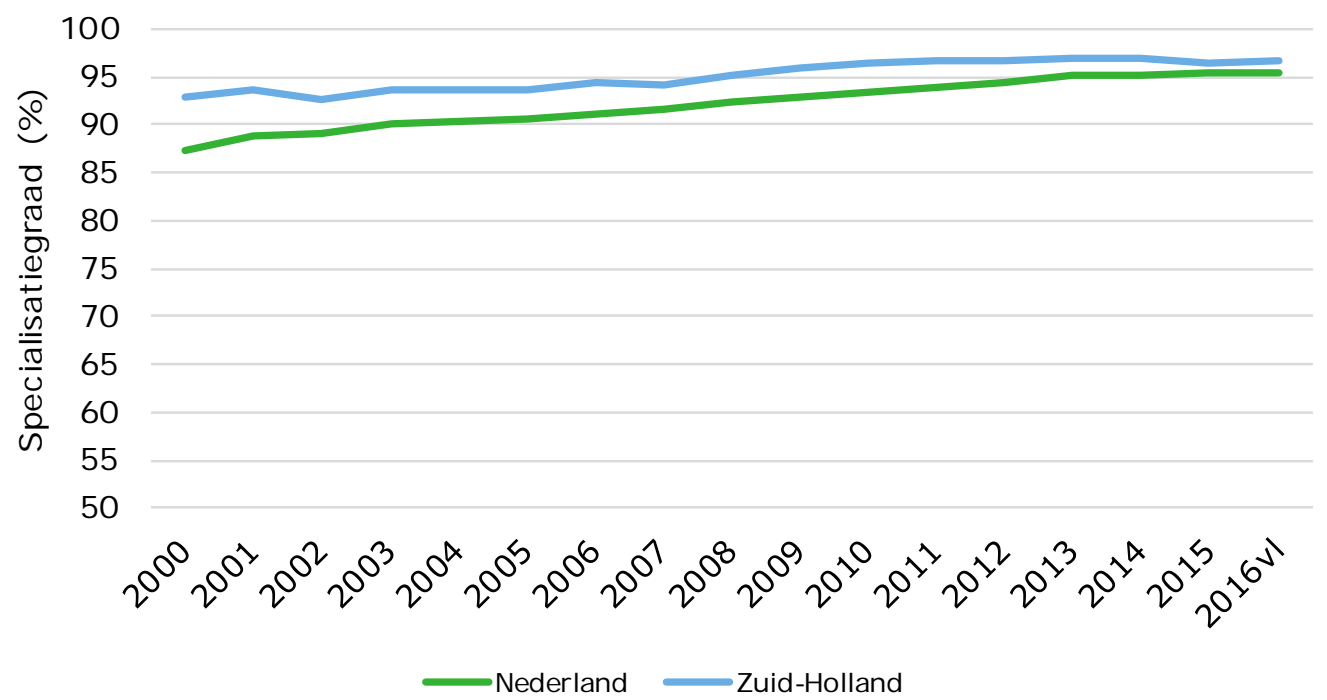

Figuur 2.8 Specialisatiegraad: aandeel van de melk- en kalfkoeien op gespecialiseerde melkveebedrijven

Bron: CBS, bewerking Wageningen Economic Research.

\subsection{Standaardverdiencapaciteit}

\section{Definitie van gehanteerde indicatoren}

De Standaardverdiencapaciteit (SVC) geeft een beeld van de vergoeding voor de inzet van arbeid en kapitaal die een bedrijf op basis van standaarden gemiddeld in een jaar behaalt met de agrarische productie, los van wie de arbeid of het kapitaal heeft geleverd (Van Everdingen, 2015).

\section{Akkerbouw}

De zeer kleine bedrijven ( $<25.000$ euro SVC) hebben een belangrijk aandeel in het totale aantal akkerbouwbedrijven in de provincie (35\%) (figuur 2.9). Echter, wanneer het gaat om de standaardverdiencapaciteit, is de bijdrage van deze zeer kleine bedrijven aan de totale standaardverdiencapaciteit op akkerbouwbedrijven in Zuid-Holland beperkt $(<5 \%)$. Op de kleinere akkerbouwbedrijven wordt er naast de teelt van de gewassen ook inkomen gegenereerd met multifunctionele landbouw of door inkomsten van buiten de landbouw. Ongeveer twee derde van de standaardverdiencapaciteit op akkerbouwbedrijven in Zuid-Holland wordt gerealiseerd op de grote ( $>100.000$ euro SVC) en zeer grote bedrijven ( $>250.000$ euro SVC).

Het aandeel van de Zuid-Hollandse akkerbouwbedrijven in de landelijke standaardverdiencapaciteit bedraagt ongeveer $8 \%$ (figuur 2.10). Ook het aandeel van het akkerbouwareaal ligt in deze orde van grootte. De arbeidsinzet ligt iets lager. Dit betekent dat er in Zuid-Holland minder arbeidskrachten per hectare worden ingezet dan gemiddeld in Nederland (zie ook hoofdstuk 3.1 Arbeidsinzet). 


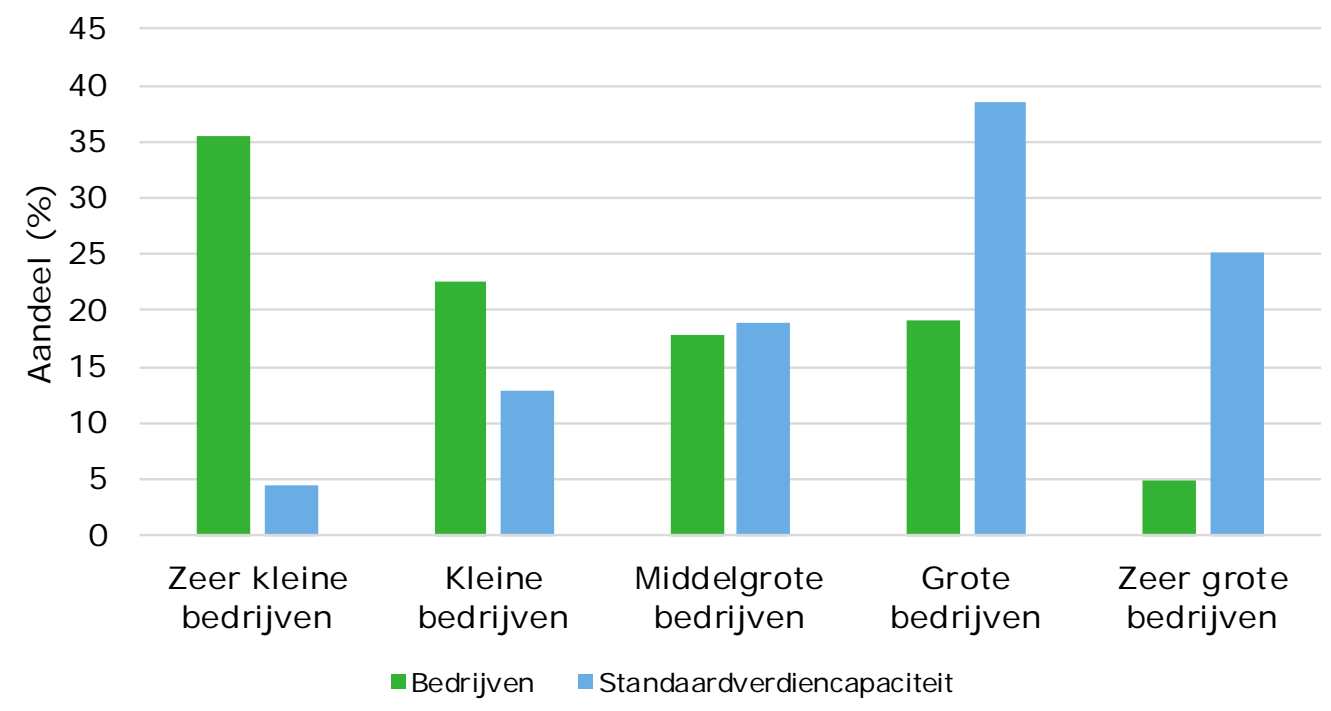

Figuur 2.9 Verdeling van het aandeel bedrijven en de standaardverdiencapaciteit (\%) naar grootteklasse voor akkerbouwbedrijven in Zuid-Holland Bron: CBS, bewerking Wageningen Economic Research.

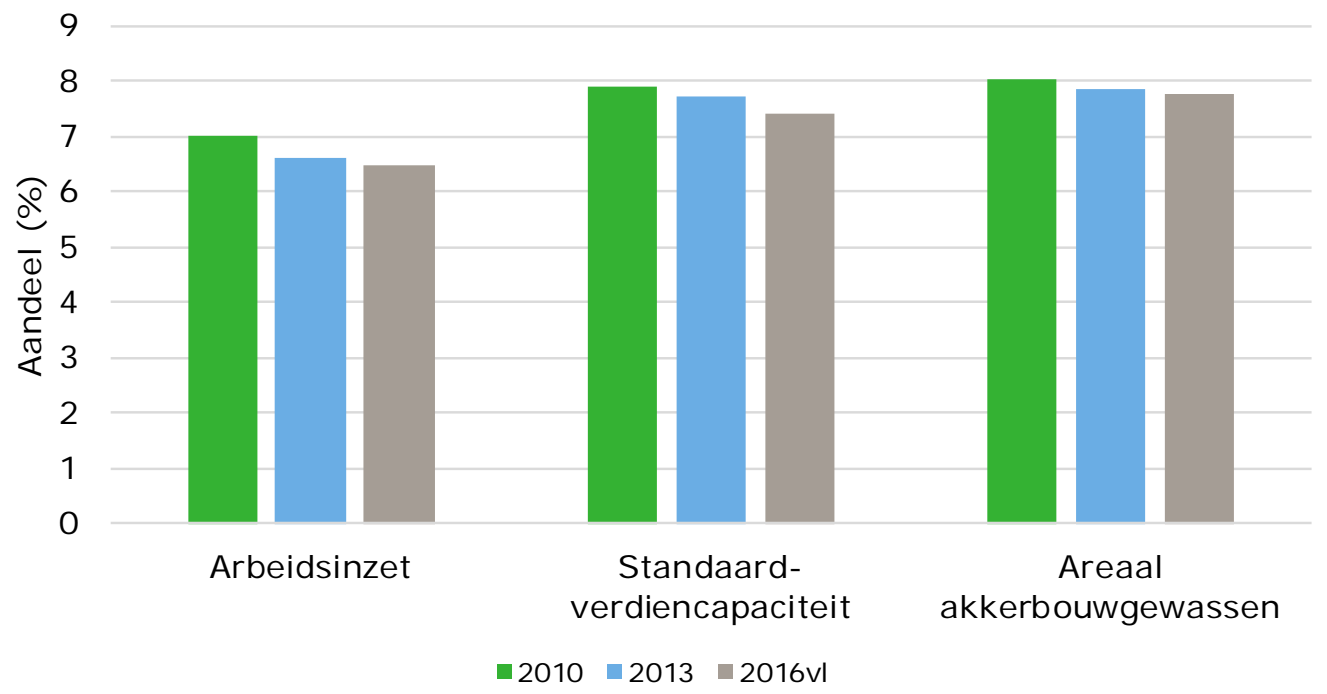

Figuur 2.10 Belang van Zuid-Hollandse akkerbouwbedrijven in het Nederlands totaal voor de arbeidsinzet op akkerbouwbedrijven, standaardverdiencapaciteit op akkerbouwbedrijven en het areaal akkerbouwgewassen

Bron: CBS, bewerking Wageningen Economic Research.

\section{Melkveehouderij}

De grote melkveebedrijven (100.000-250.000 euro SVC) in Zuid-Holland vertegenwoordigen 35\% van het aantal bedrijven en circa 50\% van de standaardverdiencapaciteit (figuur 2.11). De middelgrote bedrijven (60.000-100.000 euro SVC) met een bijna vergelijkbaar aandeel in de bedrijven, vertegenwoordigen een aanzienlijk lager aandeel (30\%) in de standaardverdiencapaciteit. 
60

50

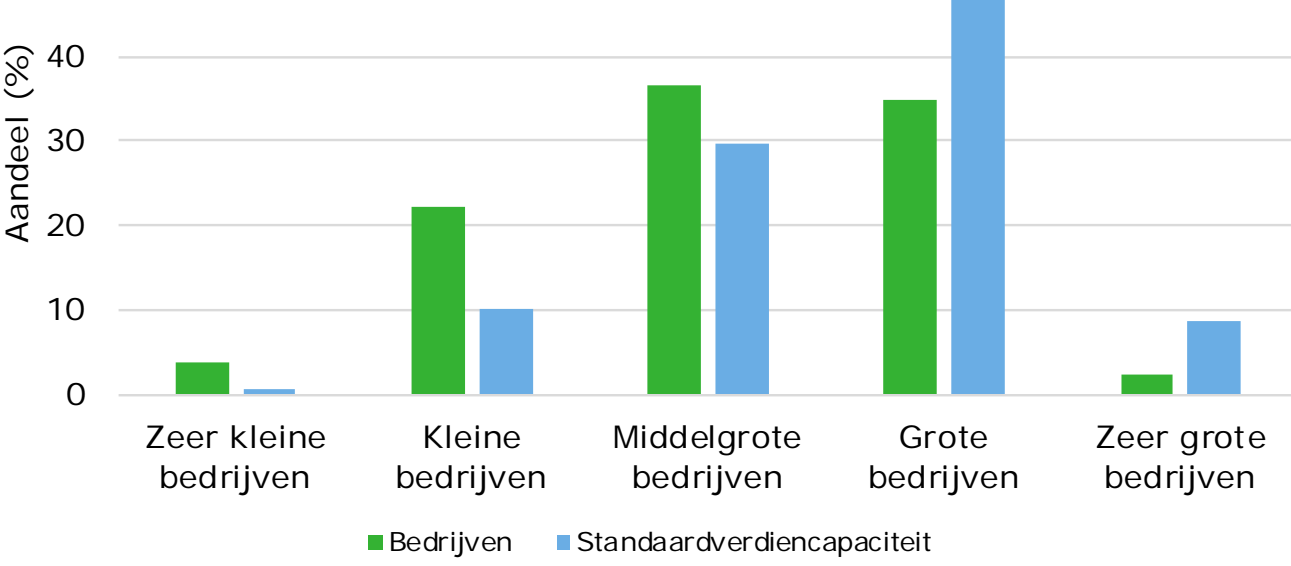

Figuur 2.11 Verdeling van het aandeel bedrijven en de standaardverdiencapaciteit naar grootteklasse voor melkveebedrijven in Zuid-Holland

Bron: CBS, bewerking Wageningen Economic Research.

Het aandeel van de Zuid-Hollandse melkveehouderij in totaal Nederland voor arbeidsinzet, standaardverdiencapaciteit en aantal melkkoeien ontlopen elkaar niet zo veel. De aandelen liggen tussen de 6 en 7\%, en kijkend naar de ontwikkeling tussen 2010 en 2016 zijn ze licht dalend (figuur 2.12). Ze hangen ook sterk met elkaar samen. De melkveehouderij in Zuid-Holland verliest dus licht terrein aan andere agrarische en niet-agrarische activiteiten.

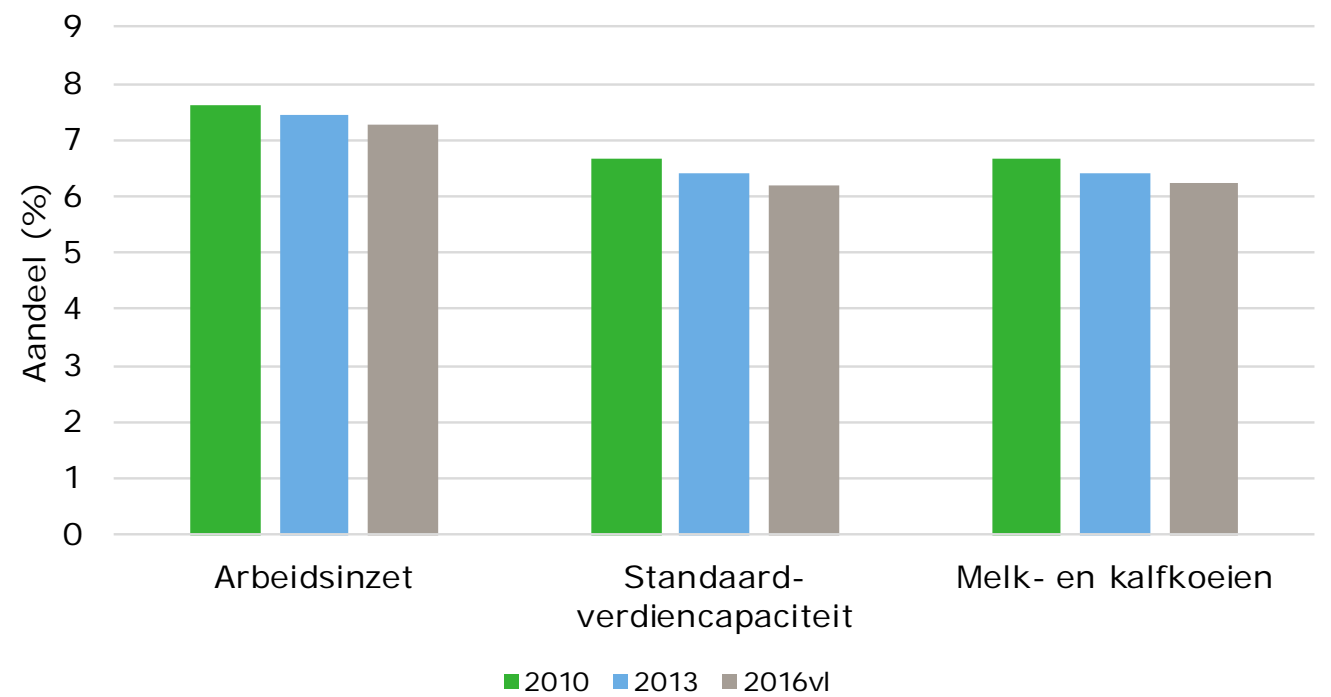

Figuur 2.12 Belang van Zuid-Hollandse melkveebedrijven in het Nederlands totaal voor de arbeidsinzet op melkveebedrijven, standaardverdiencapaciteit op melkveebedrijven en het aantal melk- en kalfkoeien Bron: CBS, bewerking Wageningen Economic Research. 


\subsection{Areaalverdeling}

\section{Definitie van gehanteerde indicatoren}

De areaalverdeling toont de oppervlakte areaal naar gewas. Dit is zowel het areaal op gespecialiseerde bedrijven, als overige bedrijven. Het areaal wordt uitgedrukt in hectares cultuurgrond.

\section{Akkerbouw}

De twee hoofdgewassen die geteeld worden in Zuid-Holland zijn tarwe (voornamelijk wintertarwe) en consumptieaardappelen (figuur 2.13). Het areaal suikerbieten daalde onder invloed van de quotering en de toename van de productie per hectare. De afschaffing van het suikerquotum in het jaar 2017, biedt kansen om de teelt uit te breiden.

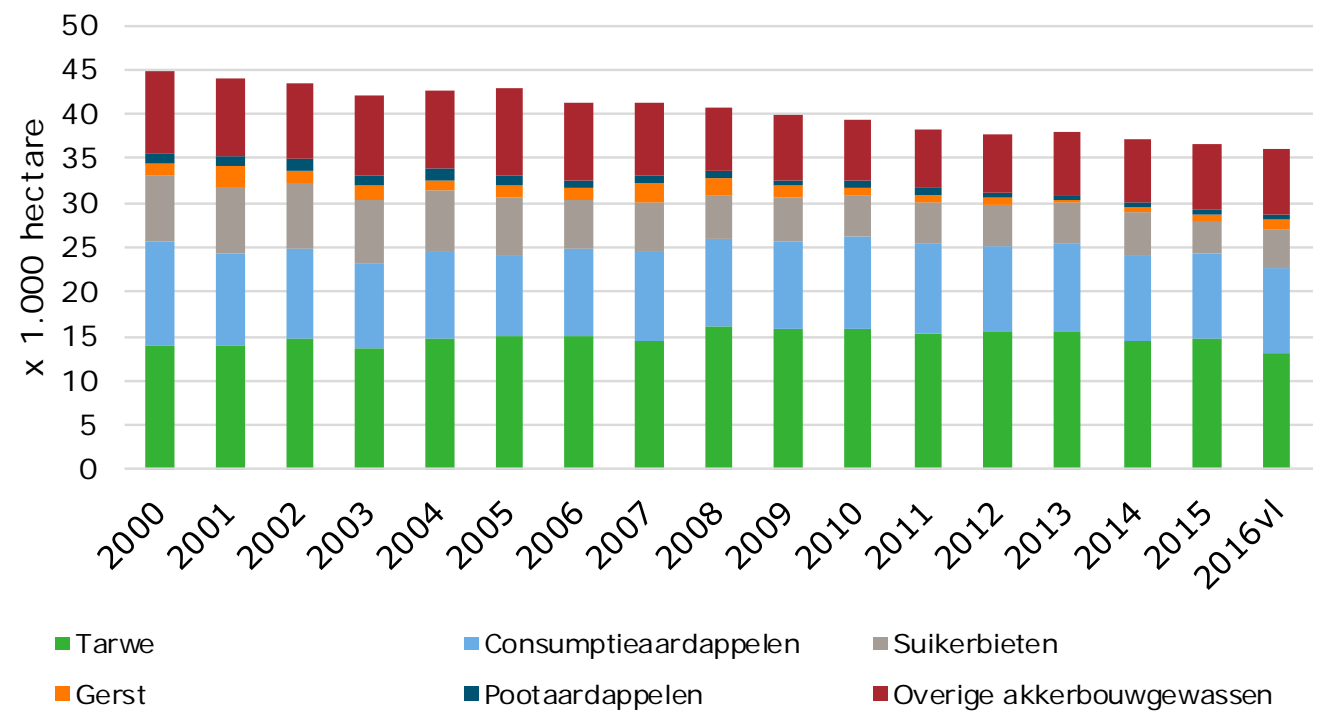

Figuur 2.13 Verdeling areaal naar gewas in Zuid-Holland

Bron: CBS, bewerking Wageningen Economic Research.

\section{Grasland en voedergewassen}

Op landbouwbedrijven in Zuid-Holland is er circa tweemaal zoveel grasland als akkerbouwgewassen (figuur 2.14). Het areaal grasland ${ }^{3}$ neemt af, gelijk aan de tendens in akkerbouwgewassen. Ten opzichte van het jaar 2000 nam in Zuid-Holland het areaal grasland met ruim $12 \%$ af. Een deel van de vrijkomende agrarische grond door stoppende (melkvee) bedrijven krijgt dus een andere bestemming.

\footnotetext{
${ }^{3}$ Dit is het areaal tijdelijk en blijvend grasland. Areaal dat gebruikt wordt voor de teelt van graszaad en graszoden valt in de categorie overige akkerbouwgewassen in figuur 2.13.
} 


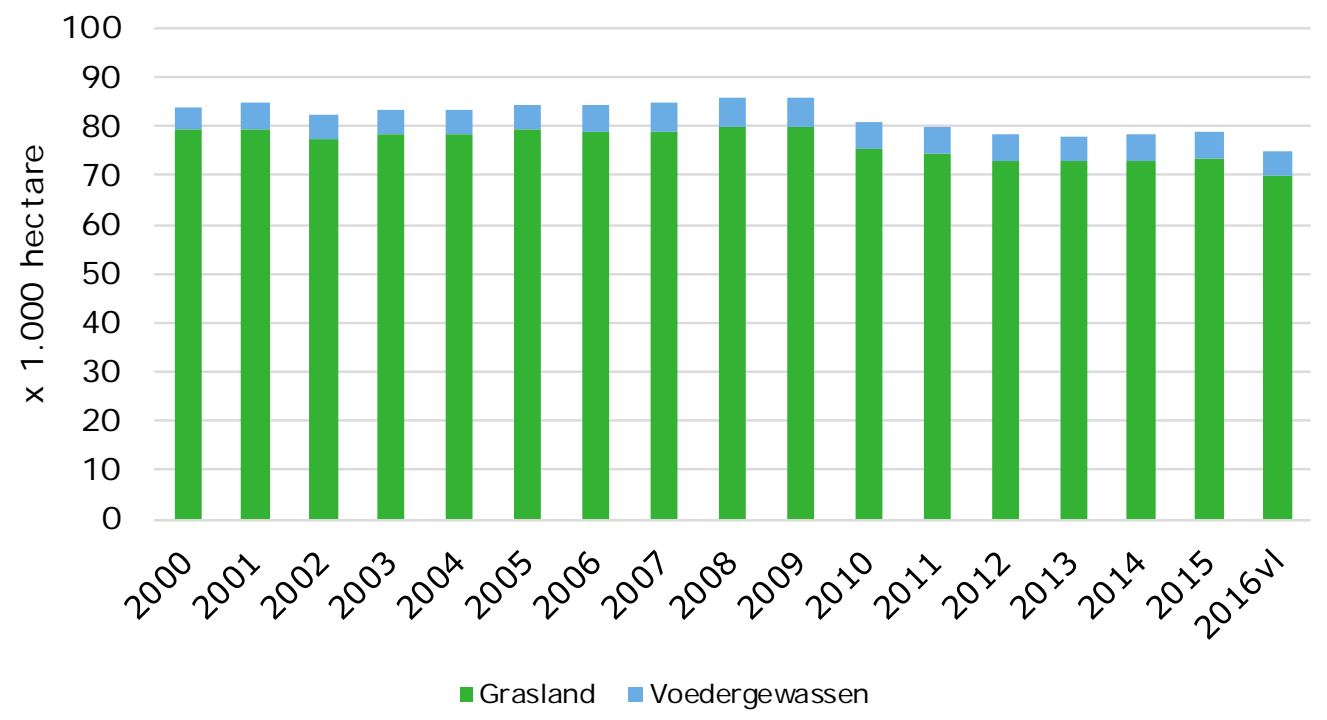

Figuur 2.14 Grasland en voedergewassen in Zuid-Holland Bron: CBS, bewerking Wageningen Economic Research.

\section{$2.4 \quad$ Productiviteit}

\section{Definitie van gehanteerde indicatoren}

De productiviteit op akkerbouwbedrijven wordt uitgedrukt als de brutogewasopbrengsten per hectare. Er wordt hierbij onderscheid gemaakt naar de belangrijkste akkerbouwgewassen. Voor de melkveehouderij wordt de productiviteit uitgedrukt als de melkproductie per melkkoe en de melkproductie per hectare voerderoppervlakte.

\section{Box 2.2 Melkproductie per hectare maakt onderdeel uit van de samengestelde effectindicator}

Voor het realiseren van kortere ketens en het sluiten van de nutriëntenkringloop is dit een zeer belangrijke indicator. De indicator melkproductie per hectare voederoppervlakte is daarom ook opgenomen in de samengestelde effectindicator voor de melkveehouderij (zie hoofdstuk 6).

\section{Akkerbouw}

Onder invloed van de weersomstandigheden doen zich forse schommelingen van de fysieke productie per hectare voor van de akkerbouwgewassen. Hierin wijkt Zuid-Holland niet af van de landelijke ontwikkelingen.

De tarweproductie in Zuid-Holland ligt in de meeste jaren net boven het landelijke niveau (figuur 2.15). Dit kan te maken hebben met de goede teeltomstandigheden, maar is ook een gevolg van het feit dat het aandeel wintertarwe in het totale areaal tarwe in Zuid-Holland vaak iets hoger ligt dan landelijk. Met wintertarwe worden hogere productie gerealiseerd dan met zomertarwe. 


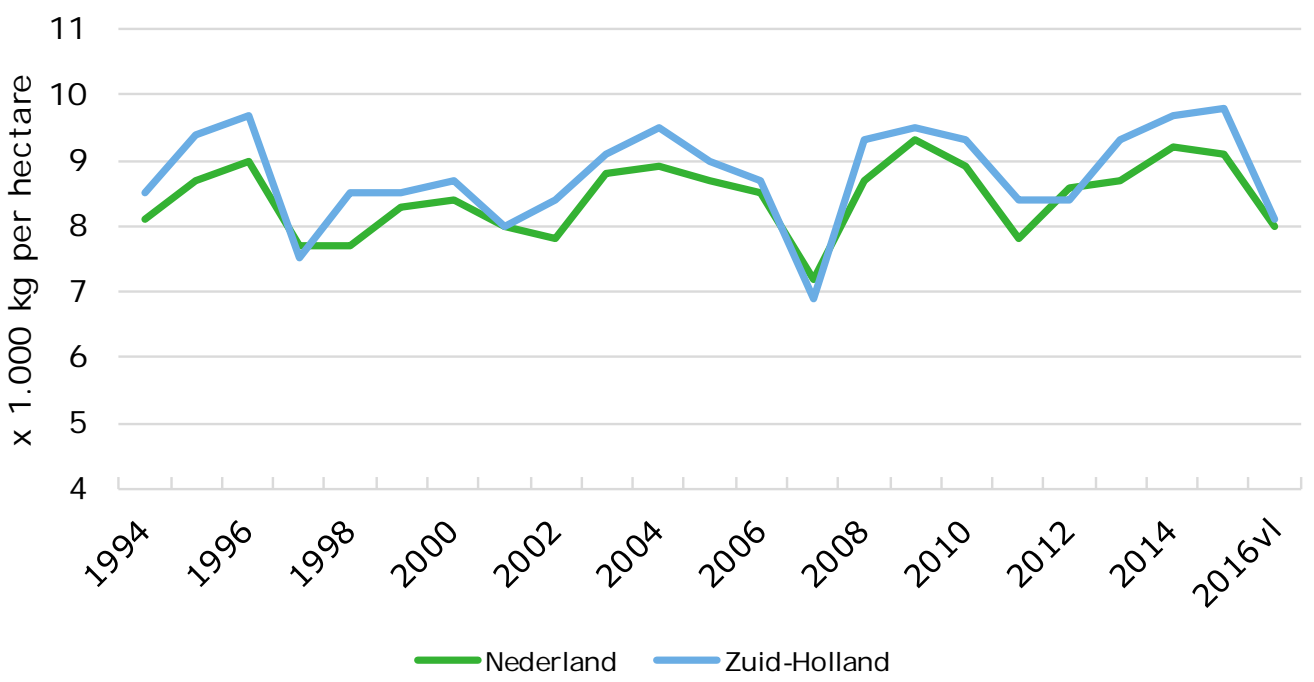

Figuur 2.15 Brutotarweopbrengst per ha

Bron: CBS, bewerking Wageningen Economic Research.

Bij suikerbieten is de gemiddelde productie per hectare flink toegenomen ten opzichte van 20 jaar geleden (figuur 2.16). Dit is het resultaat van betere rassen en de verbeteringen in de teelttechniek. Ook hier zijn er beperkte verschillen met het Nederlands gemiddelde. De brutoconsumptieaardappelenopbrengst per hectare is net als de tarwe en suikerbietenopbrengst vergelijkbaar met het nationale niveau (figuur 2.17).

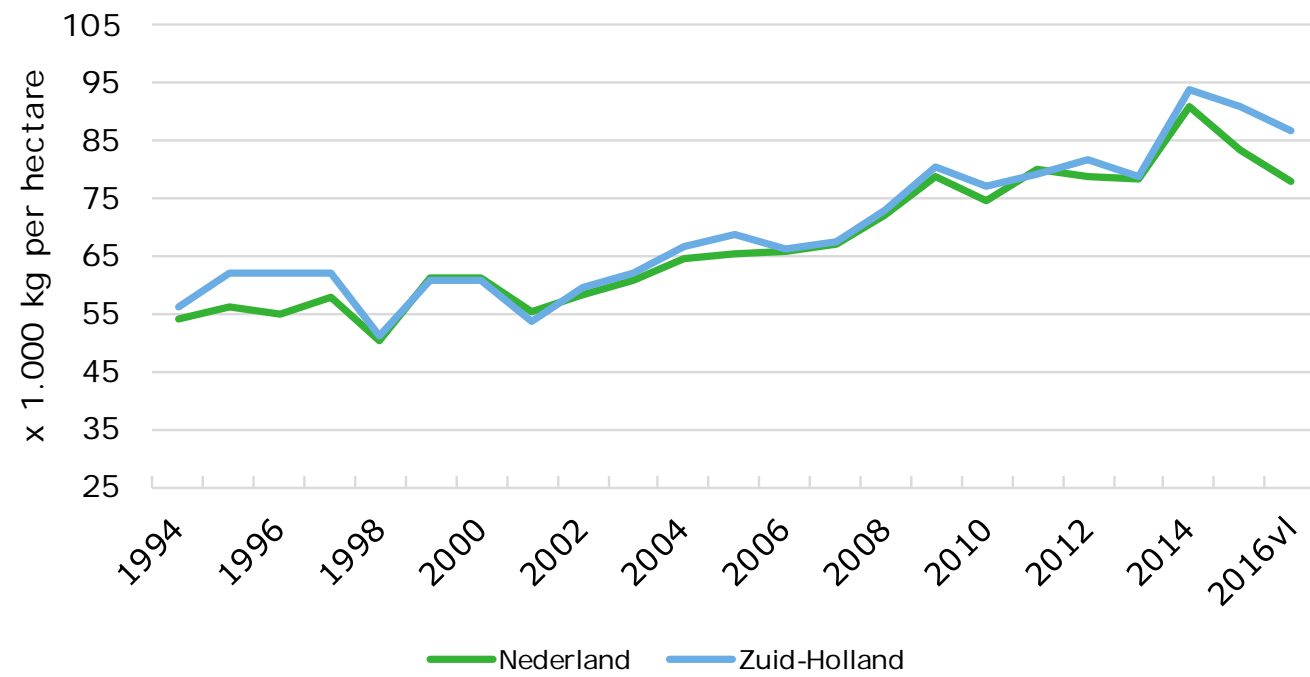

Figuur 2.16 Brutosuikerbietenopbrengst per ha

Bron: CBS, bewerking Wageningen Economic Research. 


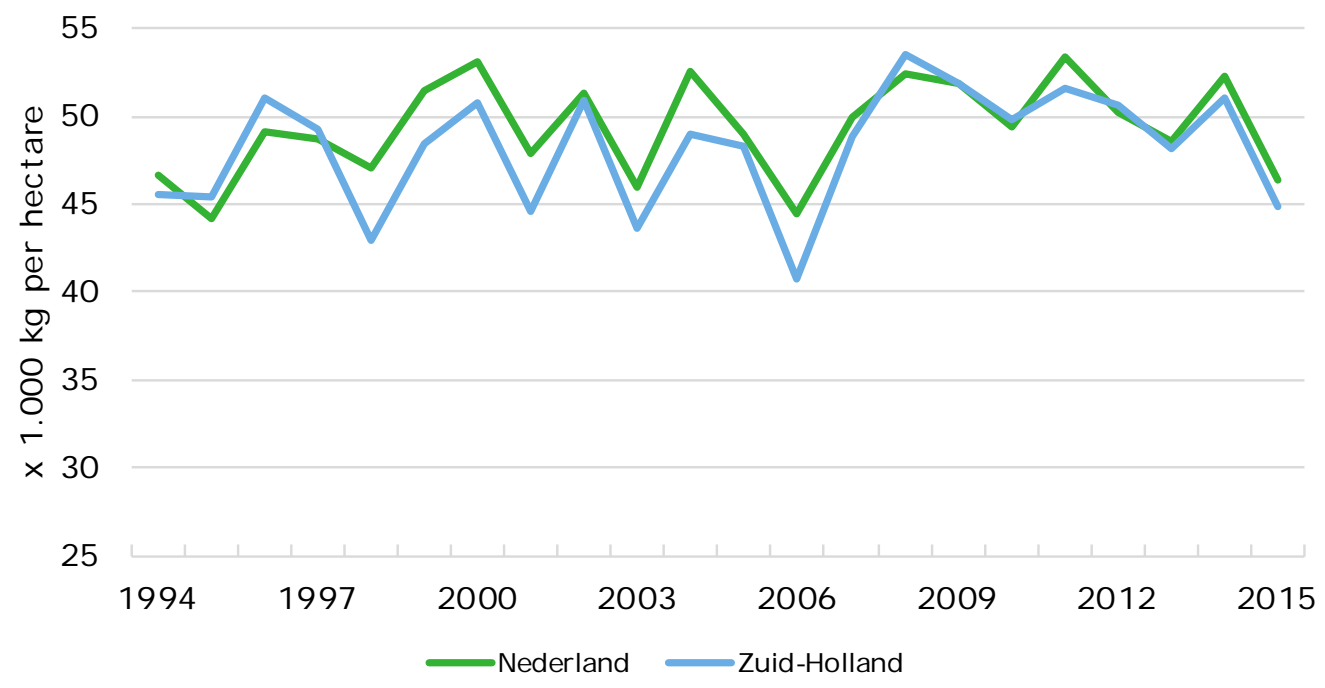

Figuur 2.17 Brutoconsumptieaardappelenopbrengst per ha Bron: CBS, bewerking Wageningen Economic Research.

\section{Melkveehouderij}

De melkproductie per koe is in Zuid-Holland per saldo tussen 2001 en 2015 met enkele procenten gestegen naar circa $7.500 \mathrm{~kg}$ in 2015 . Circa $60 \%$ van de bedrijven heeft een melkproductie per koe die bijna $+/-1.100 \mathrm{~kg}$ afwijkt van het gemiddelde (figuur 2.18).

10.000

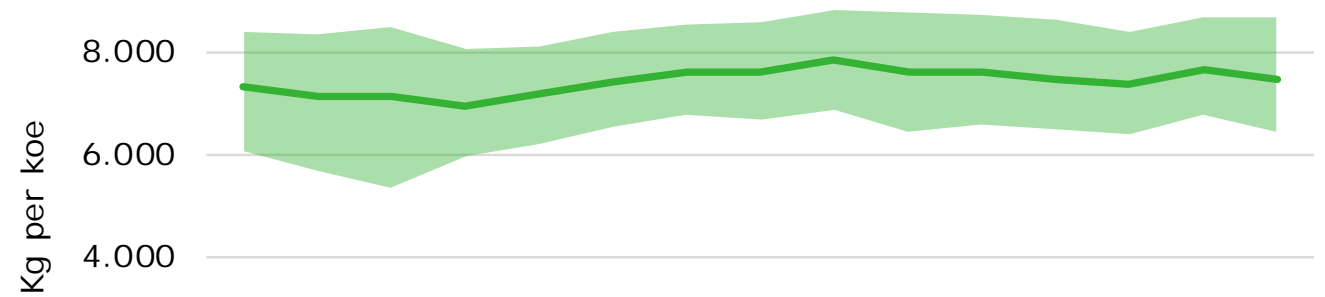

2.000

0

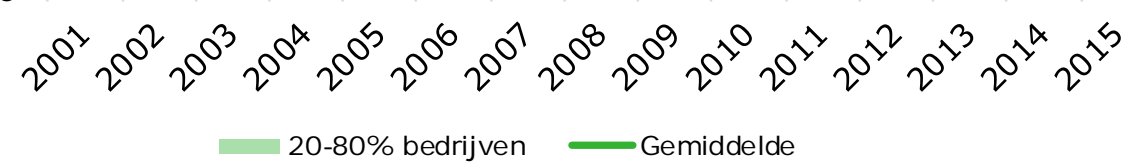

Figuur 2.18 Spreiding in melkproductie per koe op melkveebedrijven in Zuid-Holland Bron: Bedrijveninformatienet, Wageningen Economic Research.

De melkproductie per koe ligt in Nederland ca. $450 \mathrm{~kg}$ hoger dan in Zuid-Holland (figuur 2.19). Ook is er in Nederland een duidelijk stijgende tendens. De melkproductie per koe ligt in 2015 ruim 11\% hoger dan in 2000 , terwijl deze in Zuid-Holland over deze periode maar ruim $2 \%$ is gestegen. Een belangrijke verklaring hiervoor zit in het productiesysteem. Voeding beïnvloedt in hoge mate de productie per koe. Een zeer groot deel van de melkveebedrijven in Zuid-Holland bevinden zich in het veenweidegebied en bieden de veestapel een grasrijk rantsoen aan (zie ook paragraaf 3.4). Het weer kan ook van invloed zijn geweest op de kwaliteit van het ruwvoer, waardoor minder melk is geproduceerd. Een andere mogelijke oorzaak kan zijn dat boeren door de dreigende overschrijding van het melkquotum minder krachtvoer voeren met als gevolg een dalende melkproductie per koe. Dit 
gold vooral in de jaren 2011, 2012 en 2013. Dit effect is met name zichtbaar in de productie per koe in Nederland, maar kan ook een mogelijke factor in Zuid-Holland zijn.

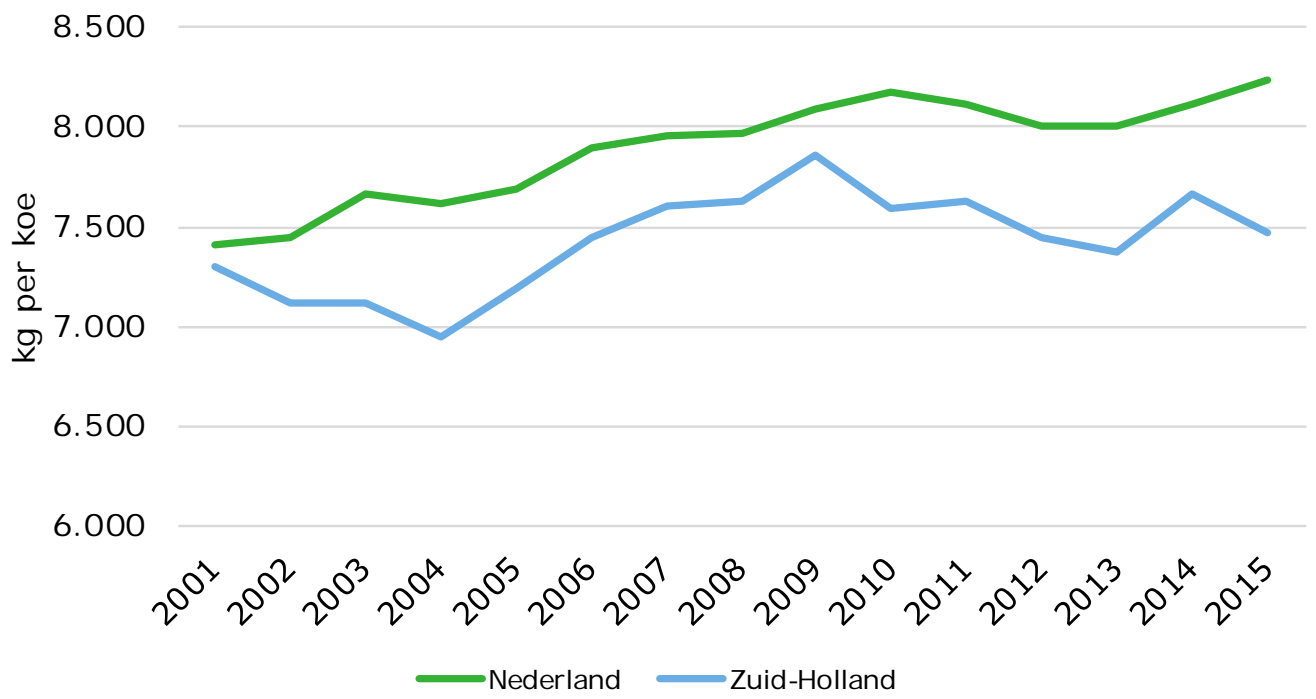

Figuur 2.19 Melkproductie per koe op melkveebedrijven in Nederland en Zuid-Holland Bron: Bedrijveninformatienet, Wageningen Economic Research.

De gemiddelde $\mathrm{kg}$ melk per ha voederoppervlakte ${ }^{4}$ schommelt rond de $12.000 \mathrm{~kg}$ op bedrijven in Zuid-Holland. In tegenstelling tot het Nederlands gemiddelde, is er geen stijgende tendens waarneembaar voor de bedrijven in Zuid-Holland. Het ene jaar is er een iets grotere spreiding dan in het andere jaar maar gemiddeld wijkt deze bijna $+/-2.900 \mathrm{~kg}$ af van het landelijk gemiddelde (figuur 2.20).

De melkveebedrijven in Zuid-Holland zijn extensiever dan het gemiddelde melkveebedrijf in Nederland (figuur 2.21). Ze bleven ook per saldo tussen 2000 en 2015 vrijwel even extensief. In Nederland zijn de bedrijven gemiddeld ruim $20 \%$ intensiever geworden. Een achterblijvende melkproductie per koe en die ook nog eens in vergelijking met de rest van Nederland nauwelijks toeneemt, ligt hieraan mede ten grondslag. Doordat melkveebedrijven in Zuid-Holland extensiever zijn, produceren ze relatief een groot deel van het voer zelf en wordt er minder voer aangekocht dan op het gemiddelde bedrijf in Nederland.

\footnotetext{
4 De oppervlakte voedergewassen is het areaal dat gebruikt wordt voor het telen voor veevoer dat zoals grasland, snijmais, luzerne en voederbieten.
} 


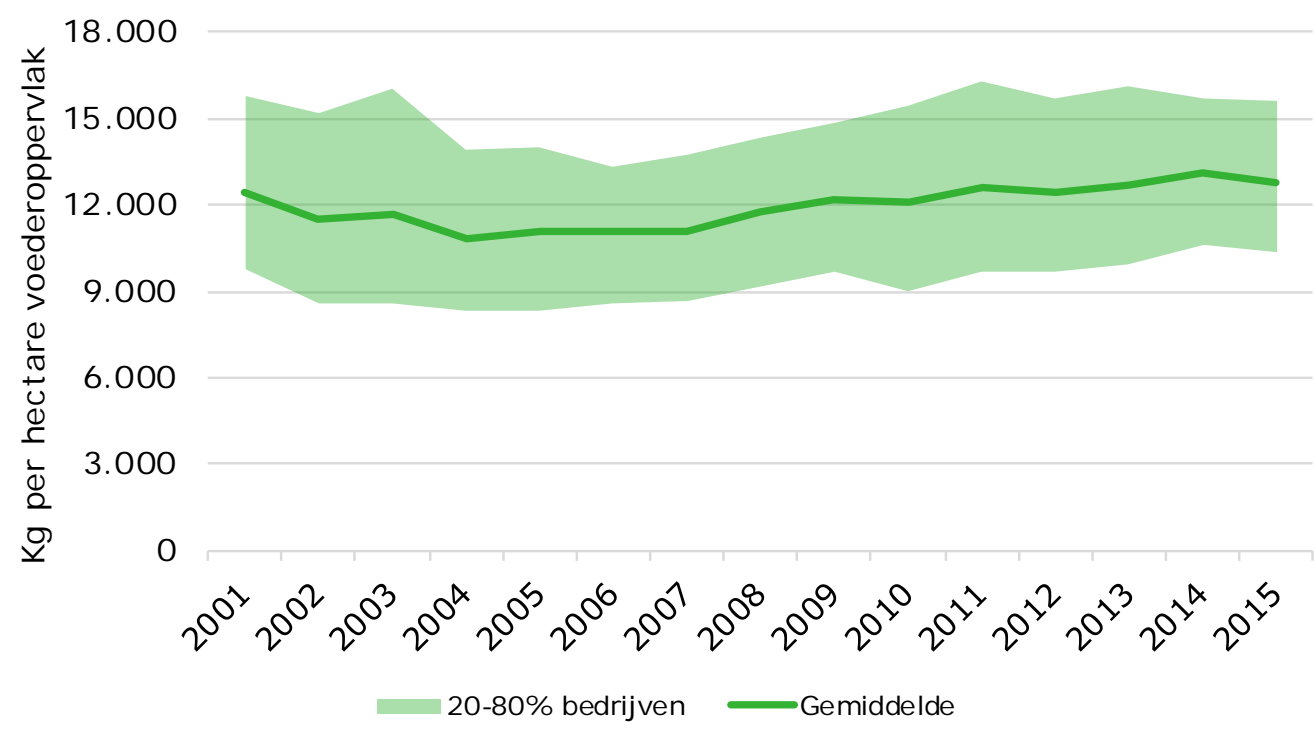

Figuur 2.20 Spreiding in melkproductie per hectare voederoppervlakte op melkveebedrijven in ZuidHolland

Bron: Bedrijveninformatienet, Wageningen Economic Research.

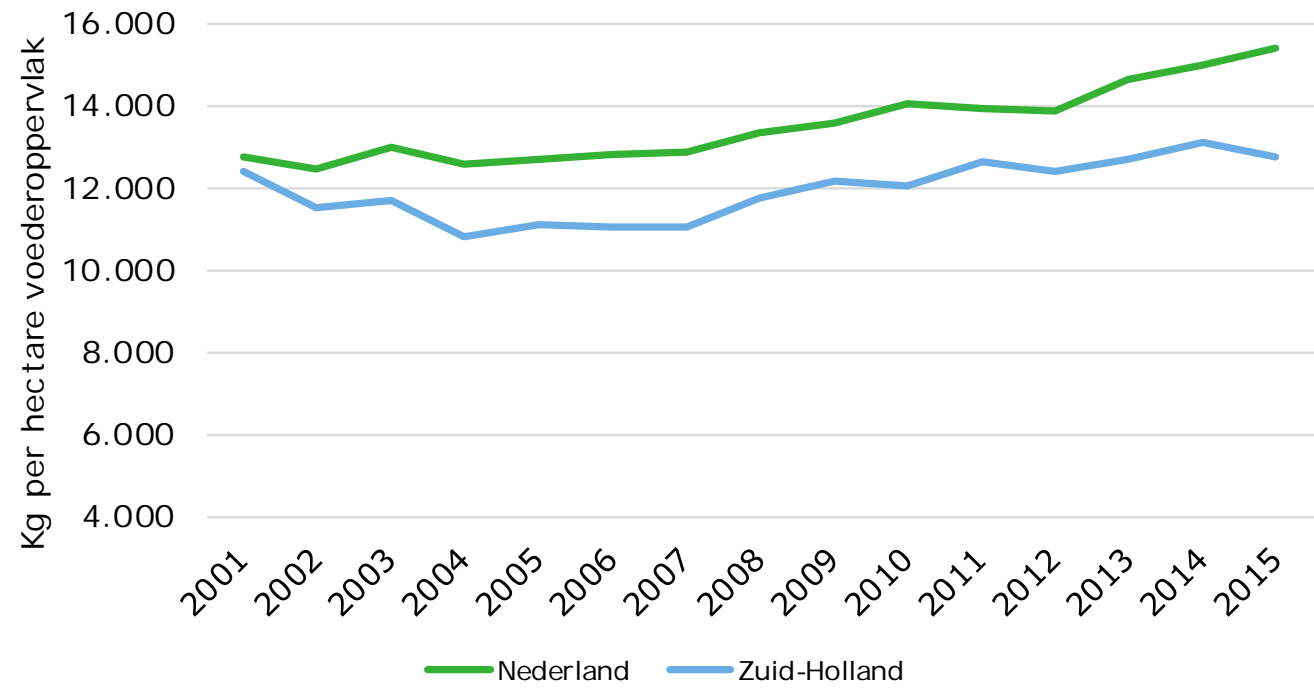

Figuur 2.21 Melkproductie per hectare voederoppervlak op melkveebedrijven Bron: Bedrijveninformatienet, Wageningen Economic Research. 


\subsection{Biologische landbouw}

\section{Definitie van gehanteerde indicatoren}

Het thema biologische landbouw wordt op twee manieren gekwantificeerd. Voor zowel de akkerbouwals melkveebedrijven wordt het aandeel van Zuid-Holland in de totale Nederlandse biologische productie getoond. Daarnaast wordt het aandeel van de biologische productie in de totale productie van Zuid-Holland. Voor beide kengetallen geldt dat dit wordt gepresenteerd voor zowel het aandeel productie-eenheden (hectares en runderen) en het aandeel van de bedrijven met die productieeenheden.

\section{Akkerbouw}

In 2016 waren er 17 bedrijven met biologische akkerbouwgewassen in Zuid-Holland en een oppervlakte van 38.576 ha biologische akkerbouwgewassen. In 2011 waren dit 25 bedrijven en 34.031 ha biologische akkerbouwgewassen. Het aandeel Zuid-Hollandse bedrijven dat biologische akkerbouwgewassen teelt in het totaal aan biologische akkerbouwbedrijven in Nederland, vertoont een dalende lijn. In 2012 waren ongeveer 6\% van de biologische bedrijven met akkerbouwgewassen gevestigd in Zuid-Holland, vier jaar later is dit bijna gehalveerd. Het aandeel Zuid-Holland in het nationaal totaal van areaal biologische gewassen is wel op peil gebleven (figuur 2.22). Ongeveer $1 \%$ van het areaal akkerbouwgewassen in Zuid-Holland wordt biologisch geteeld (figuur 2.23).

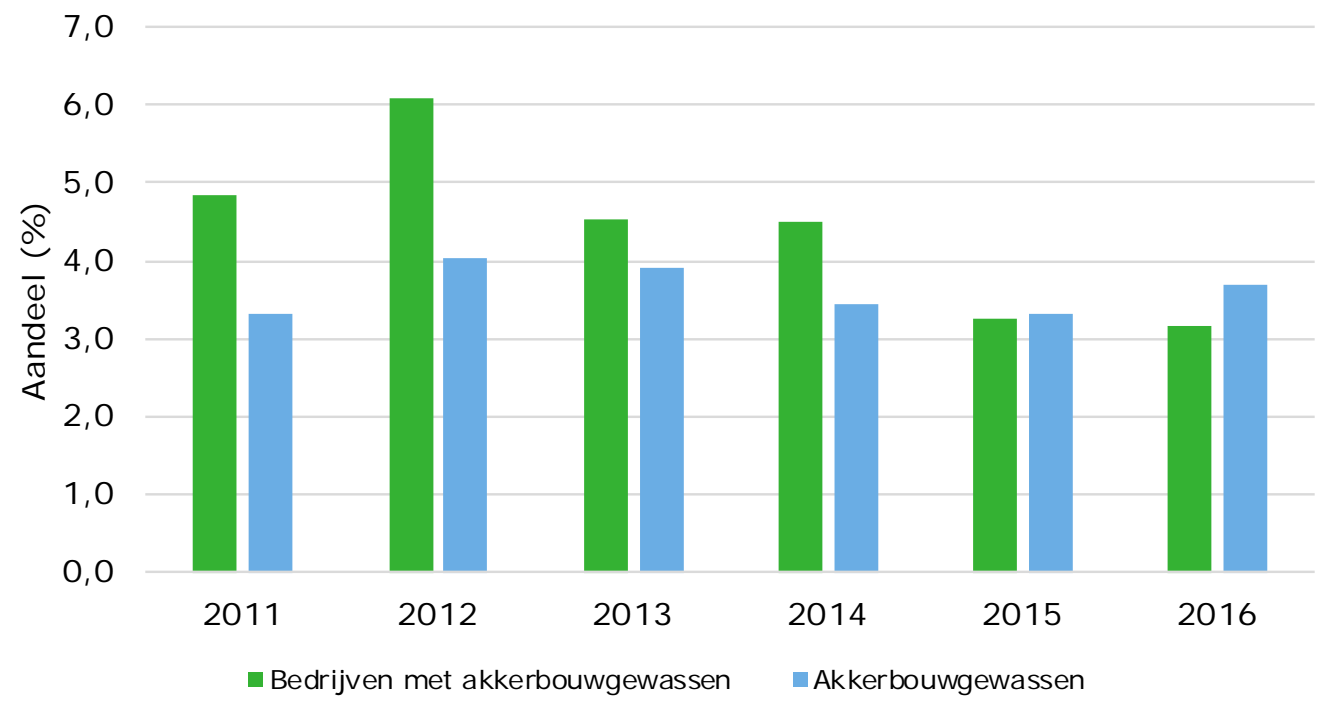

Figuur 2.22 Aandeel van Zuid-Hollandse biologische akkerbouwgewassen in het totaal aan biologische akkerbouwgewassen in Nederland Bron: CBS, bewerking Wageningen Economic Research. 


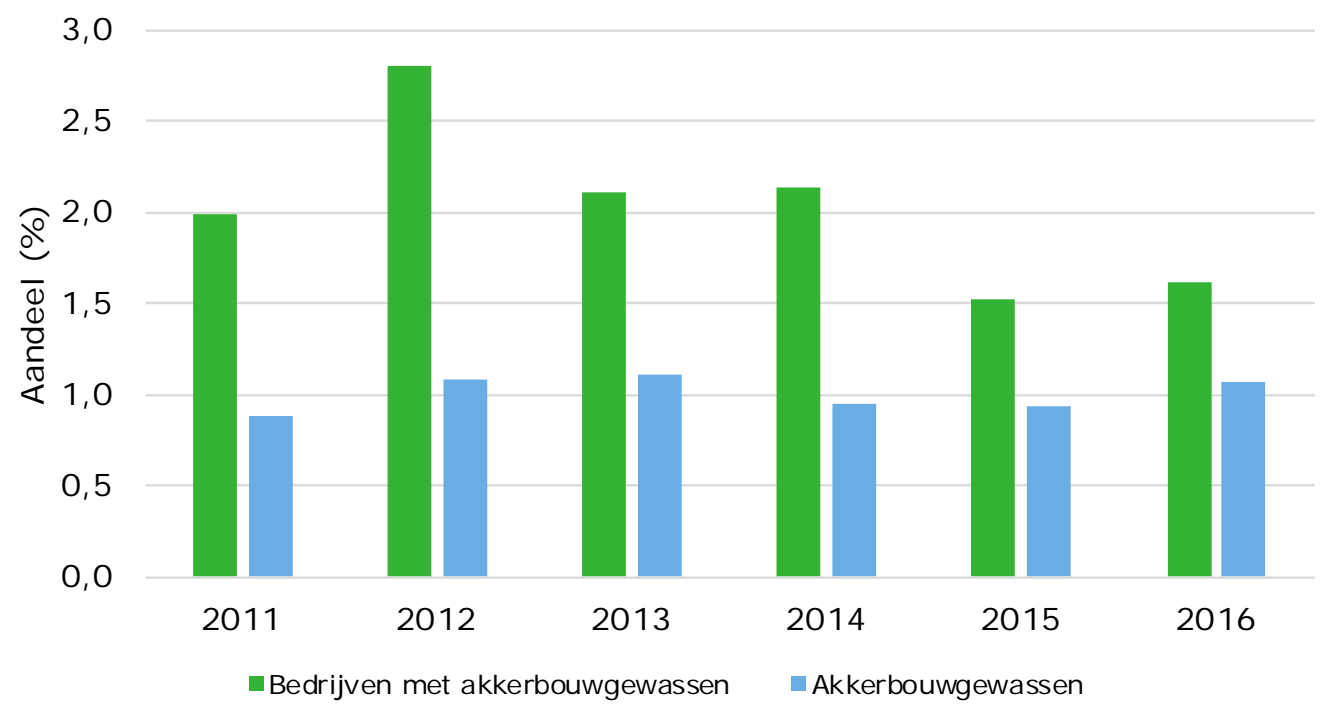

Figuur 2.23 Aandeel van biologische akkerbouwgewassen in het totaal aan akkerbouwgewassen in Zuid-Holland

Bron: CBS, bewerking Wageningen Economic Research.

\section{Melkveehouderij}

In 2016 waren er 37 bedrijven met biologische gehouden runderen in Zuid-Holland en een aantal van 4.588 biologische runderen. In 2011 waren dit 34 bedrijven en 3.419 biologische runderen. ZuidHolland heeft een aandeel van 5 tot $7 \%$ in het aantal bedrijven met biologische runderen ${ }^{5}$ en het aantal biologisch gehouden runderen van geheel Nederland (figuur 2.24). In 2014 en 2015 is dit aandeel iets gedaald, maar kwam vervolgens in 2016 weer op het niveau van 2011 te liggen. ZuidHolland heeft naar verhouding nauwelijks meer biologische melkveebedrijven dan de rest van Nederland.

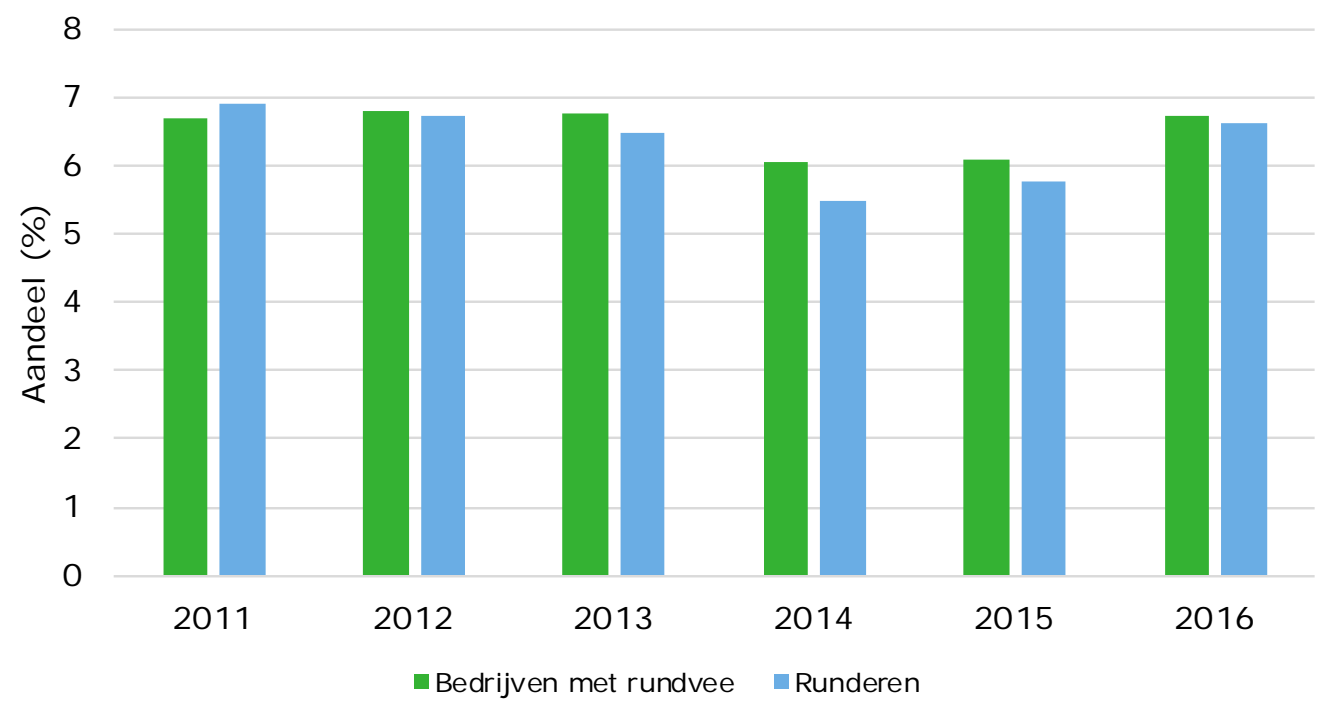

Figuur 2.24 Aandeel van Zuid-Hollandse biologische runderen in het totaal biologische runderen in Nederland

Bron: CBS, bewerking Wageningen Economic Research.

\footnotetext{
5 Melk- en kalfkoeien, jongvee en vleesvee.
} 
Het aandeel bedrijven met biologische runderen en aandeel biologische runderen ondergaat dezelfde ontwikkeling en lag in 2011 tussen de 1,5 en 2\%, terwijl deze in 2016 iets toegenomen is en tussen de 2 en 2,5\% ligt (figuur 2.25). Evenals in figuur 2.24, daalt dit aandeel in 2014 en 2015 iets door een afname van 5 biologische bedrijven. Doordat het aantal biologische bedrijven gering is (tussen de 30 en 40), worden de relatieve verschillen al snel vrij groot.

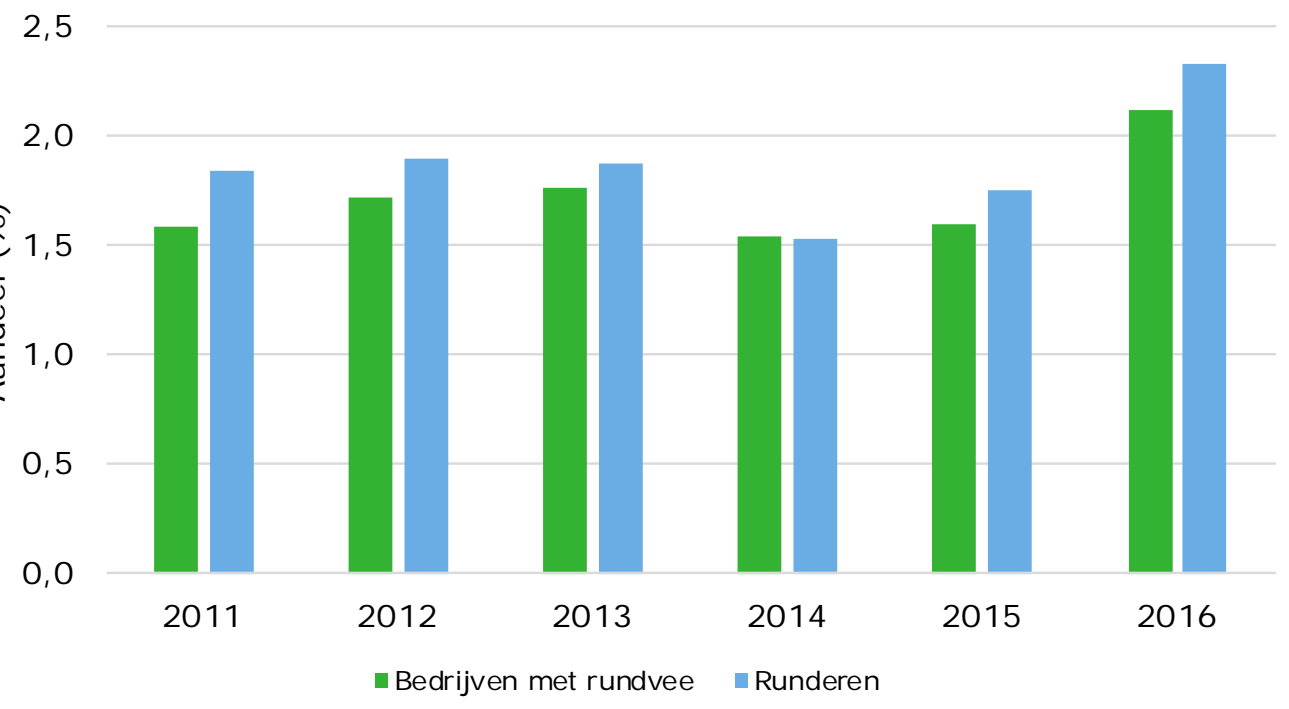

Figuur 2.25 Aandeel van biologische runderen in het totaal runderen in Zuid-Holland Bron: CBS, bewerking Wageningen Economic Research. 


\section{People}

\subsection{Arbeidsinzet}

\section{Definitie van gehanteerde indicatoren}

De landbouw is een belangrijke sector als het gaat om werkgelegenheid. Het aandeel vast personeel in de landbouw daalt ten opzichte van flexibel personeel. De sector wordt gekenmerkt door veel onbetaalde arbeidsinzet. Dit is de arbeidsinzet van de ondernemer en zijn of haar gezinsleden. Een arbeidskracht die 2.000 uur of meer werkt, wordt gezien als 1 arbeidsjaareenheid. Een arbeidskracht die minder dan 2.000 uur werkt, wordt naar rato van het aantal uren dat hij/zij werkt, omgerekend naar arbeidsjaareenheden. Een belangrijk deel van de arbeid op agrarische bedrijven wordt geleverd door de ondernemers en hun gezinsleden. Dit betreft onbetaalde arbeid (ook bij ondernemingen met rechtspersoonlijkheid (bv) worden de uren die door de ondernemer zijn gemaakt, meegerekend als onbetaalde arbeid).

\section{Akkerbouw}

Gemiddeld werken er ongeveer 1,4 arbeidsjaareenheden (aje) op een akkerbouwbedrijf in ZuidHolland. De meeste arbeid op de akkerbouwbedrijven wordt verzorgd door de ondernemer en het gezin. In Zuid-Holland bedroeg de arbeidsinzet in 2016 ruim 1.000 aje. De inzet van betaalde arbeidskrachten was ongeveer $20 \%$ van de totale bezetting (figuur 3.1). Door de jaren heen is de inzet van onbetaalde arbeidskrachten ongeveer gelijk gebleven bij een lichte afname van de betaalde krachten.

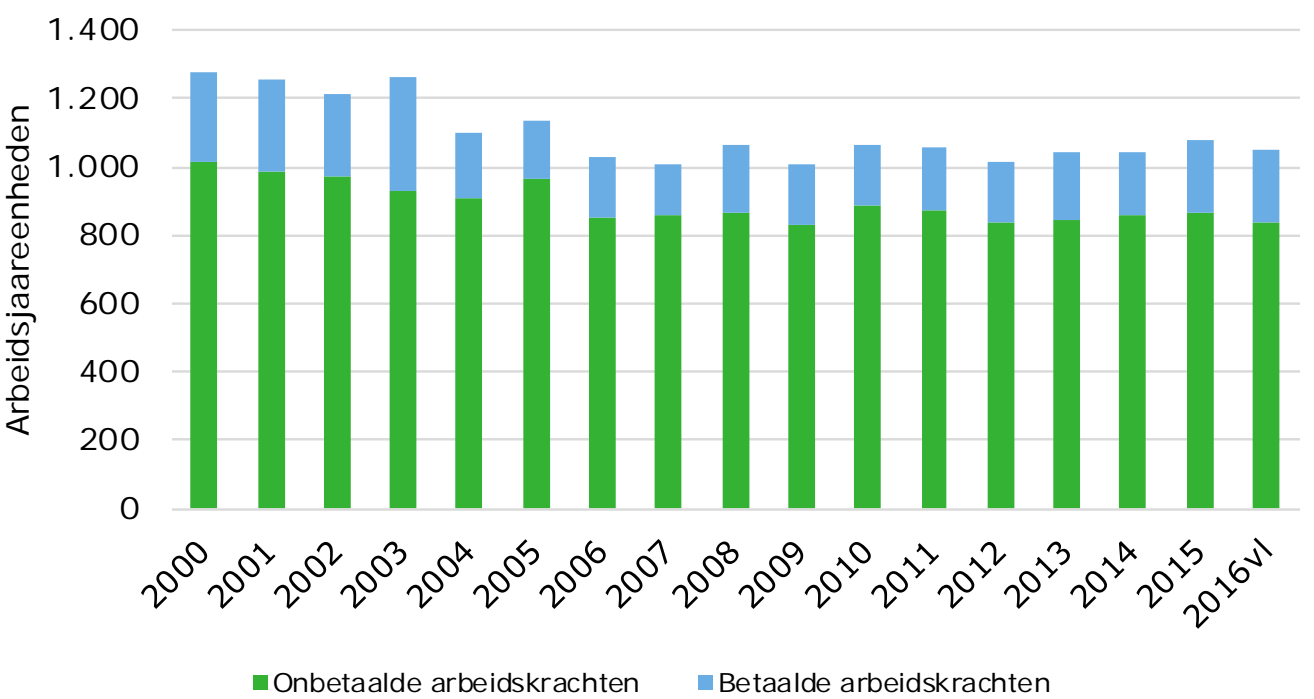

Figuur 3.1 Arbeidsinzet op akkerbouwbedrijven in Zuid-Holland Bron: CBS, bewerking Wageningen Economic Research.

Per hectare wordt op de akkerbouwbedrijven in Zuid-Holland minder arbeid ingezet dan gemiddeld in Nederland (figuur 3.2). Dit kan zowel het gevolg zijn van de schaalgrootte van de bedrijven waardoor schaalvoordelen kunnen worden behaald in de arbeidsinzet. Maar het is ook het gevolg van een andere samenstelling van het bouwplan. In Zuid-Holland worden minder pootaardappelen en akkerbouwmatige groenten geteeld. Dit zijn akkerbouwgewassen die een relatief grote arbeidsinzet vragen. 


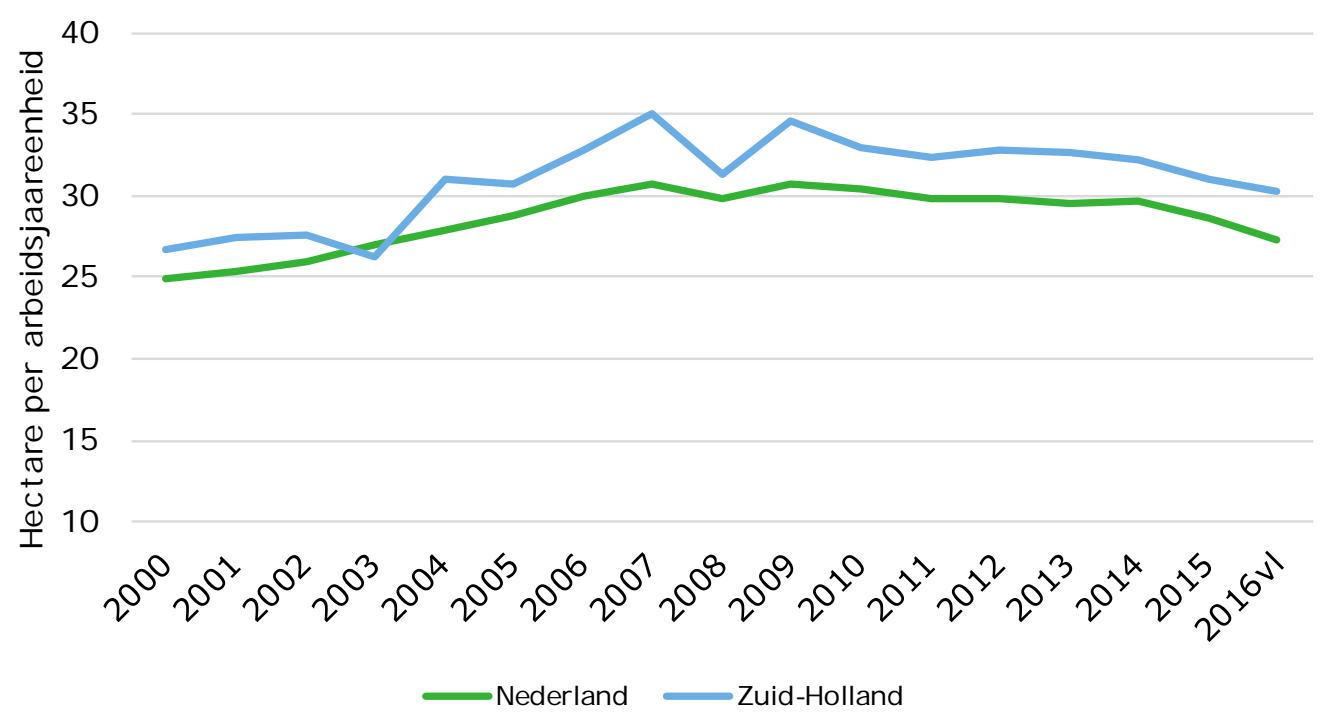

Figuur 3.2 Oppervlakte cultuurgrond per arbeidsjaareenheid op akkerbouwbedrijven Bron: CBS, bewerking Wageningen Economic Research.

\section{Melkveehouderij}

Gemiddeld werken er ongeveer 2,0 arbeidsjaareenheden (aje) op een melkveebedrijf in Zuid-Holland. De meeste arbeid op de melkveebedrijven wordt verzorgd door de ondernemer en het gezin. Het aantal aje in de melkveehouderij in Zuid-Holland neemt de laatste jaren niet meer af. Er is ook een kleine verschuiving naar een groter aandeel betaalde arbeid. Was het aandeel in 2000 nog $7 \%$ in 2016 is dit opgelopen naar bijna $10 \%$ (figuur 3.3).

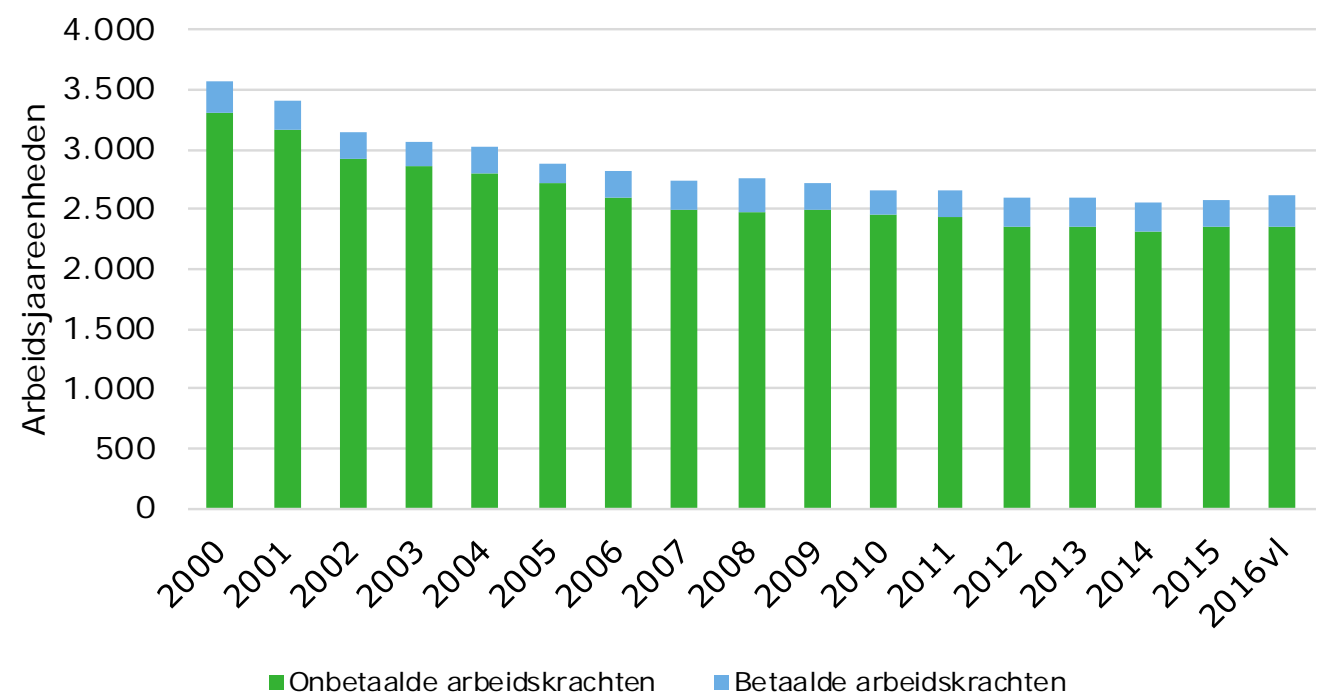

Figuur 3.3 Arbeidsinzet op melkveebedrijven in Zuid-Holland Bron: CBS, bewerking Wageningen Economic Research.

Het aantal koeien per aje is in Zuid-Holland lager dan het landelijke beeld (figuur 3.4). Dit wordt veroorzaakt doordat de melkveebedrijven in Zuid-Holland kleiner en extensiever zijn. Ook is de melkproductie per koe lager waardoor je meer koeien (dus arbeidsinzet) nodig hebt om dezelfde hoeveelheid melk te produceren. Het verschil in aantal koeien per aje neemt ook toe. De melkveebedrijven in Zuid-Holland groeien ook minder snel en hierdoor blijven de schaalgroottevoordelen ook achter bij de rest van Nederland. 


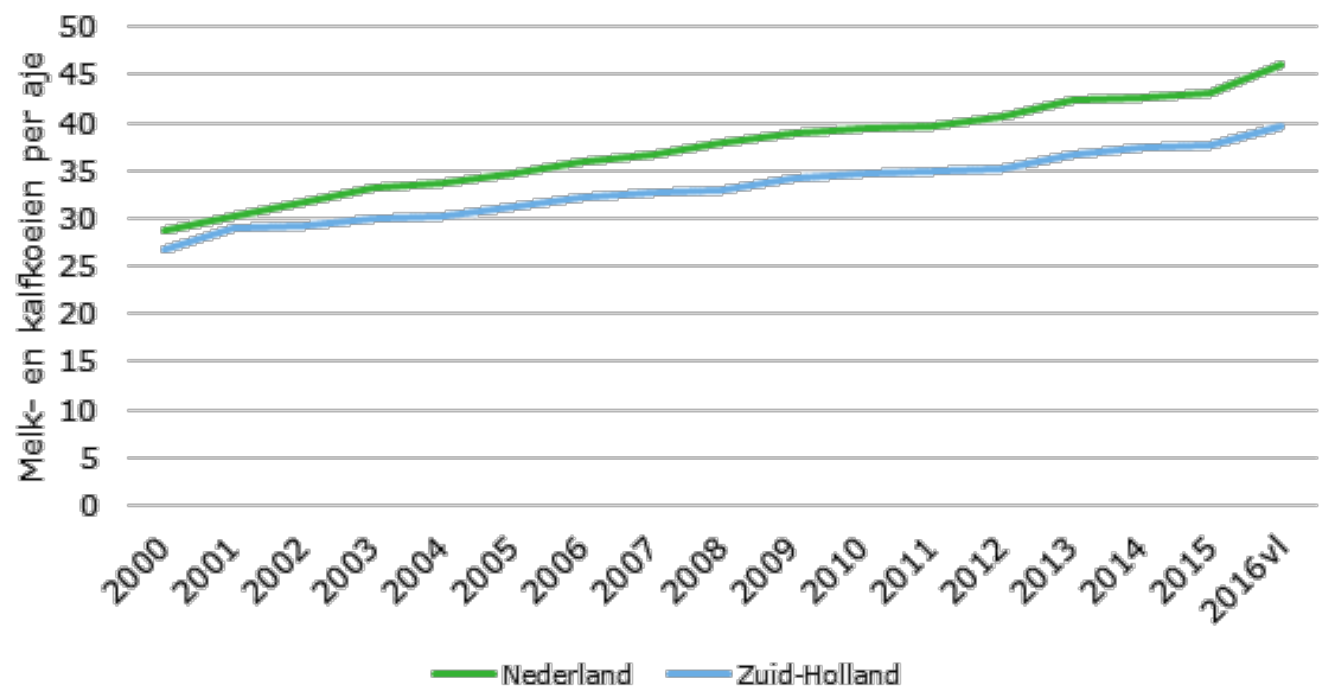

Figuur 3.4 Melk- en kalfkoeien per arbeidsjaareenheid op melkveebedrijven Bron: CBS, bewerking Wageningen Economic Research.

\subsection{Bedrijfsopvolging}

\section{Definitie van gehanteerde indicatoren}

In de Landbouwtelling wordt elke vier jaar aan de persoonlijke ondernemingen met een oudste bedrijfshoofd van 51 jaar of ouder gevraagd naar de aanwezigheid van een opvolger op het bedrijf. Die informatie kan worden gezien als een indicatie voor de continuïteit van bedrijven. De vraag over bedrijfsopvolging wordt niet gesteld aan rechtspersonen. Op basis van de indeling in bovengenoemde vier klassen, is het aandeel van de groep continuerende bedrijven vastgesteld: dat zijn de bedrijven uit de klassen 1 (rechtspersonen), 2 (ondernemer $<51$ jaar) en 3 (ondernemer >= 51 jaar met een opvolger). Het uitgangspunt daarbij is dat de bedrijven met een oudere ondernemer zonder opvolger, binnen een tijdsbestek van 10 tot 15 jaar het bedrijf zullen beëindigen. Uiteraard geldt daarbij dat de situatie in de toekomst nog kan veranderen: niet alle bedrijven met een opvolger zullen daadwerkelijk worden opgevolgd en van de groep zonder opvolger kan later toch blijken dat er wel opvolging plaatsvindt.

\section{Box 3.1 Aandeel continuerende bedrijven maakt onderdeel uit van de samengestelde effectindicator}

Voor de continuïteit van de sector is dit een belangrijke indicator. Dit kengetal geeft inzicht in het aantal bedrijven dat in een tijdsbestek van 10 tot 15 jaar zal beëindigen op basis van opvolgingssituatie. Uiteraard geldt daarbij dat de situatie in de toekomst nog kan veranderen: niet alle bedrijven met een opvolger zullen daadwerkelijk worden opgevolgd en van de groep zonder opvolger kan later toch blijken dat er wel opvolging plaatsvindt. Deze indicator past goed bij de doelstelling die in het ambitiedocument gesteld is: een sterke economisch cluster op lange termijn in stand houden. De indicator 'aandeel continuerende bedrijven' is opgenomen in de samengestelde effectindicator voor akkerbouw en de melkveehouderij (zie hoofdstuk 6).

\section{Akkerbouw}

Sinds 2000 neemt het aantal bedrijven met een bedrijfsopvolger af in Zuid-Holland (figuur 3.5). Dit heeft vooral te maken met een daling van het totale aantal bedrijven, want het aandeel bedrijven met opvolger steeg. In 2016 heeft ongeveer twee derde van de bedrijven een opvolger of is de ondernemer jonger dan 51 jaar. Het aantal rechtspersonen (die tot bedrijven met opvolging worden gerekend) is beperkt in de akkerbouw. 
Het aandeel continuerende bedrijven in Zuid-Holland is fors groter dan gemiddeld in Nederland (figuur 3.6). Blijkbaar zien veel ondernemers voldoende perspectief in de akkerbouw in dit gebied. Dit kan mede te maken hebben met de schaalgrootte van de bedrijven in Zuid-Holland. De grotere bedrijven hebben over het algemeen betere perspectieven voor continuatie dan kleinere.

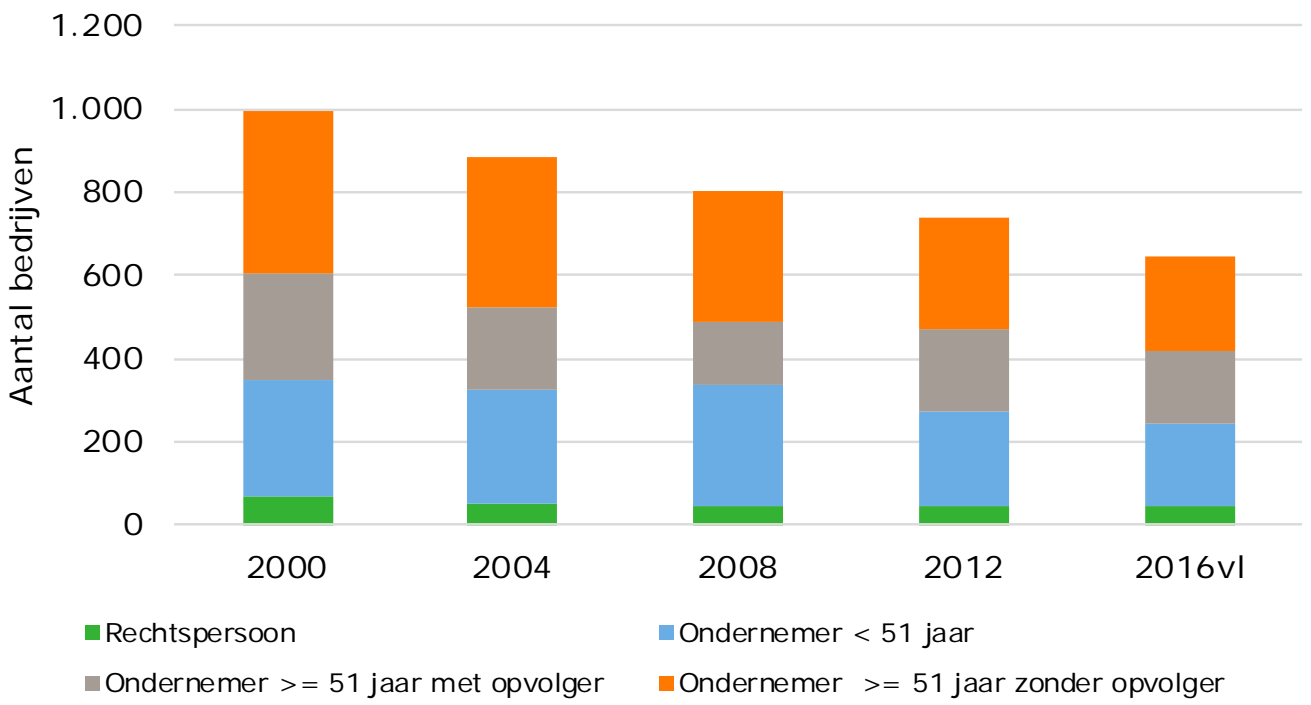

Figuur 3.5 Opvolgingssituatie op akkerbouwbedrijven in Zuid-Holland Bron: CBS, bewerking Wageningen Economic Research.

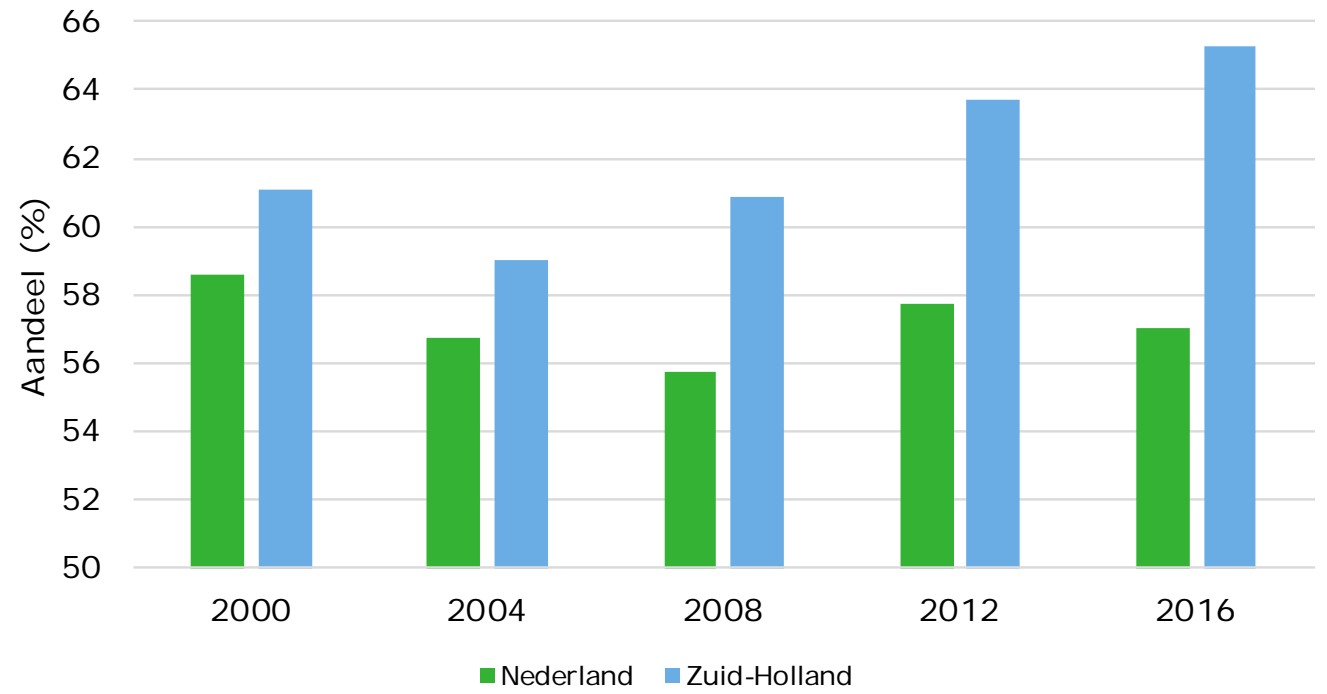

Figuur 3.6 Aandeel continuerende akkerbouwbedrijven Bron: CBS, bewerking Wageningen Economic Research.

\section{Melkveehouderij}

Het aandeel van de melkveebedrijven met een opvolger daalt in Zuid-Holland over een langere periode (figuur 3.7). Tussen 2012 en 2016 is deze vrij stabiel. In deze periode neemt vooral het aantal bedrijven met een ondernemer jonger dan 51 jaar af. De vergrijzing neemt de laatste jaren dus sterk toe. 


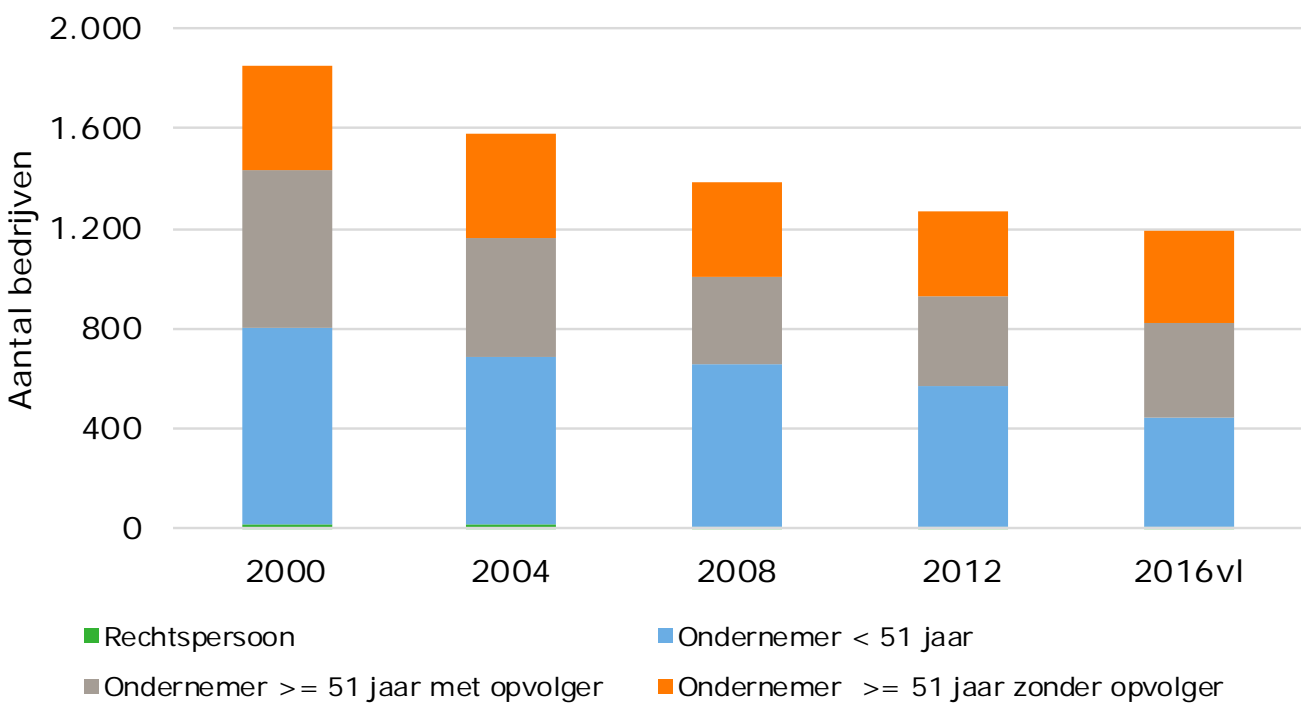

Figuur 3.7 Opvolgingssituatie op melkveebedrijven in Zuid-Holland Bron: CBS, bewerking Wageningen Economic Research.

Het aandeel continuerende melkveebedrijven in Zuid-Holland blijft achter bij het landelijke beeld (figuur 3.8). Zowel het Zuid-Hollandse als het landelijke beeld laat een daling zien van dit aandeel. Door de vergrijzing neemt het aandeel bedrijven met een ondernemer $>51$ jaar zonder opvolger toe. Hierdoor daalt het continuïteitspercentage.

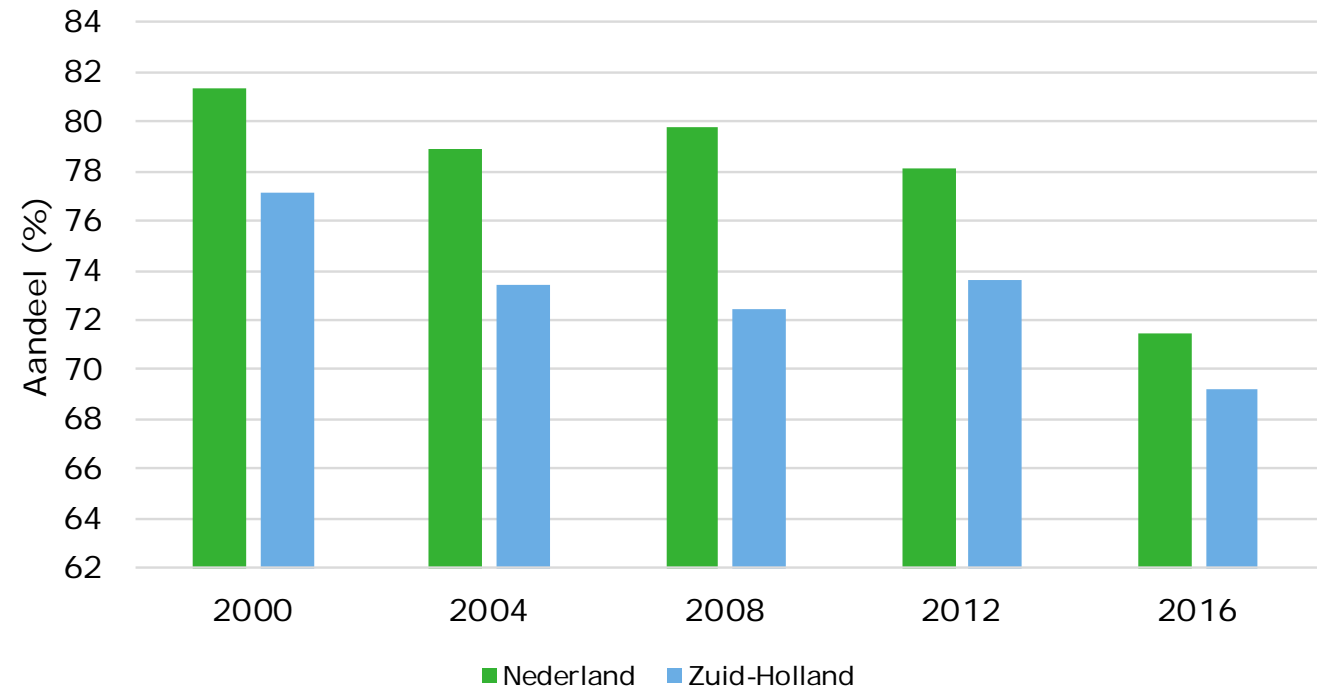

Figuur 3.8 Aandeel continuerende melkveebedrijven Bron: CBS, bewerking Wageningen Economic Research. 


\subsection{Dierenwelzijn- en gezondheid}

\section{Definitie van gehanteerde indicatoren}

Voor dierenwelzijn- en gezondheid wordt van twee indicatoren gebruik gemaakt: aandeel melkveebedrijven dat weidegang toepast en het aandeel integraal duurzame stallen. Het aandeel duurzame stallen wordt samengesteld op basis van het aantal stallen op biologische veehouderijbedrijven, stallen die voldoen aan de Maatlat Duurzame Veehouderij, stallen die voldoen aan het Beter Leven keurmerk, stallen die voldoen aan het Milieukeur certificaat, en stallen die voldoen aan de voorwaarden van de Investeringsregeling Integraal Duurzame Stallen. Het gaat om stallen en houderijsystemen die het dierenwelzijn extra verbeteren door het toepassen van maatregelen die verder gaan dan de wettelijke welzijnsnormen en die daarnaast ten minste voldoen aan andere maatschappelijke randvoorwaarden en wettelijke eisen voor milieu, diergezondheid en arbeidsomstandigheden én economisch haalbaar zijn (Van der Peet et al., 2016).

Box 3.2 Aandeel melkveebedrijven met weidegang en aandeel integraal duurzame stallen maken onderdeel uit van de samengestelde effectindicator

Het aandeel weidende melkveebedrijven is bepalend voor het Nederlandse landschap en bevordert het dierenwelzijn. Het aandeel integraal duurzame stallen heeft relatie met meerdere duurzaamheidthema's in de melkveehouderij. De indicatoren zijn daarom opgenomen in de samengestelde effectindicator voor de melkveehouderij (zie hoofdstuk 6).

\section{Weidegang}

De melkveehouderij in de provincie Zuid-Holland wordt gekenmerkt door een extensieve bedrijfsvoering met een hoog aandeel grasland in het bouwplan. Daarnaast zijn melkveebedrijven in Zuid-Holland gemiddeld kleiner dan in de rest van Nederland. Deze omstandigheden maken het gunstig om weidegang toe te passen. In vergelijking met andere gebieden in Nederland passen de melkveebedrijven in Zuid-Holland dan ook relatief vaak weidegang toe. In het weideseizoen 2015, pasten $92 \%$ van de melkveebedrijven een vorm van beweiding van melkkoeien toe. Dat is een stijging van $1 \%$ ten opzichte van het voorgaande jaar. Ter vergelijking: in geheel Nederland pasten $75 \%$ van de melkveebedrijven weidegang toe (figuur 3.9).

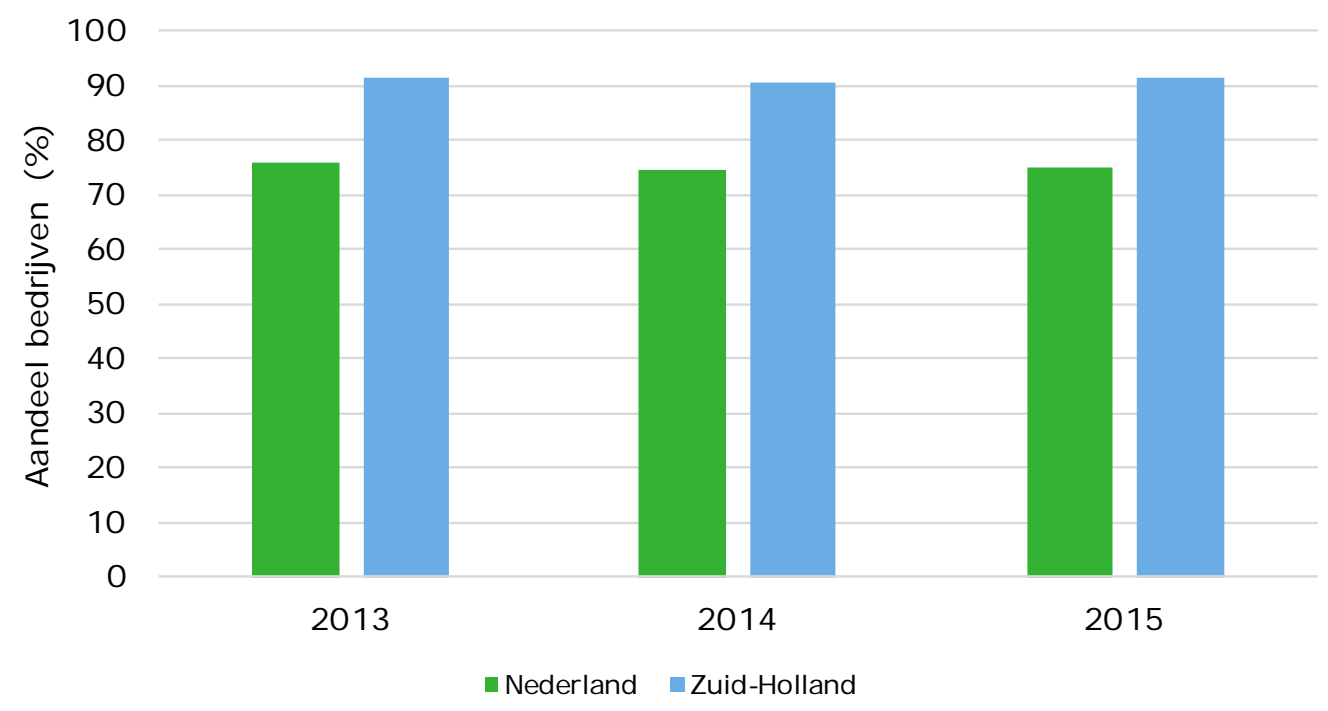

Figuur 3.9 Aandeel melkveebedrijven dat een vorm van weidegang toepast Bron: CBS, bewerking Wageningen Economic Research. 
Behoud van weidegang is één van de vier duurzaamheidsthema's in de Duurzame Zuivelketen. De Duurzame Zuivelketen streeft naar het behoud van weidegang, omdat deze bepalend is voor het beeld dat de maatschappij heeft van de Nederlandse zuivelsector (Reijs et al., 2016). In 2012 is in het Convenant Weidegang vastgelegd om ten minste het niveau van weidegang van 2012 te behouden en dat er gestreefd wordt naar het bieden van weidegang van minimaal 120 dagen per jaar, ten minste 6 uur per dag. De inspanningen van de meer dan 70 ondertekenaars om het behoud van weidegang te behouden wordt jaarlijks gerapporteerd in de voortgangsrapportage van het Convenant Weidegang (Duurzame Zuivelketen, 2016).

\section{I ntegraal duurzame stallen}

In 2016 waren er in Zuid-Holland 19 melkveestallen gerealiseerd die voldoen aan de Maatlat Duurzame Veehouderij (MDV) en daarnaast zijn er nog voor 22 melkveestallen het MDV-certificaat aangevraagd, maar (nog) niet gerealiseerd. In 2016 waren er 56 biologische melkveestallen. ${ }^{6}$ Er zijn geen melkveestallen die Beter Leven gecertificeerd zijn en er zijn geen vleesveestallen in Zuid-Holland die integraal duurzaam zijn. Het aantal melkvee- en vleesveestallen in Zuid-Holland bedraagt respectievelijk 2.564 en 64 stallen. Het aandeel integraal duurzame rundveestallen in de provincie Zuid-Holland bedraagt daarmee 3,9\%. Dat is lager dan het landelijk gemiddelde dat op 1 januari 2016 op 7,6\% lag (figuur 3.10). Een mogelijke verklaring is dat de verhouding tussen melkveestallen en overige rundveestallen anders is dan in de rest van Nederland. Het aandeel vleesveebedrijven is zeer beperkt in Zuid-Holland en het Beter Leven keurmerk is alleen van toepassing op vleesvee- en vleeskalverstallen. Bijna een derde van de in Nederland integraal duurzame rundveestallen zijn stallen met een Beter Leven keurmerk.

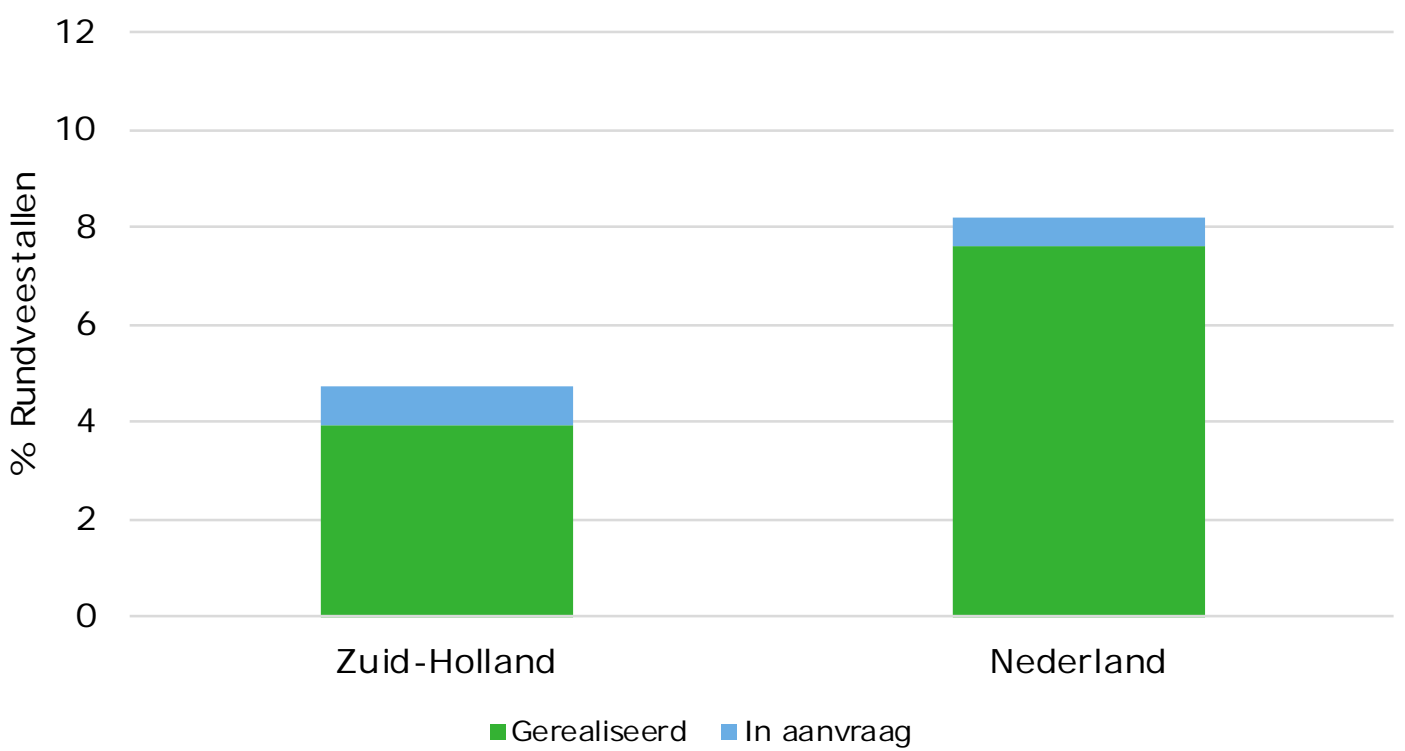

Figuur 3.10 Aandeel integraal duurzame stallen a)

a) Peildatum Zuid-Holland is 1 januari 2017; Peildatum Nederland is 1 januari 2016.

Bron: Bedrijveninformatienet, Landbouwtelling, SKAL, SMK, EZ-Dienst Regelingen, Beter Leven keurmerk, KDV.

De overheid ambieert een integraal duurzame veehouderij in 2023. Het ministerie van Economische Zaken hanteert sinds 2007 een ambitie voor duurzame stallen. Dit wordt vanaf het jaar 2009 jaarlijks gemonitord. De streefwaarde bij deze ambitie duurzame stallen stijgt ieder jaar. De ambitie is dat het aandeel integraal duurzame stallen eind 2016 14\% van de stallen bedraagt. Het betreft zowel pluimvee-, varkens- als rundveestallen (Van der Peet et al., 2016).

\footnotetext{
${ }^{6}$ De gegevens van de provincie Zuid-Holland zijn per 1 januari 2017. Op het moment van het verschijnen van deze nota, is het landelijk gemiddelde nog niet bekend en wordt voor Nederland gebruik gemaakt van informatie met als peildatum 1 januari 2016.
} 


\subsection{Duurzaam voedsel}

Er is geen indicator beschikbaar die meet wat de duurzame voedselconsumptie is in de provincie ZuidHolland. Wel wordt op landelijk niveau op basis van data van Wageningen Economic Research, CBS, Foodstep en Bionext jaarlijks het marktaandeel duurzaam voedsel berekend, als aandeel van de totale consumentenbestedingen aan voedsel. De totale consumentenbestedingen aan duurzaam voedsel in de steekproef van winkels en andere outlets in de drie onderzochte verkoopkanalen bedroegen 3 miljard euro in 2015. Het marktaandeel duurzaam voedsel binnen de totale voedselbestedingen is gestegen van 7\% in 2014 naar 8\% in 2015 (Logatcheva, 2016). 


\section{$4 \quad$ Planet}

\subsection{Klimaat en energie}

\section{Definitie van gehanteerde indicatoren}

Voor de akkerbouw en de melkveehouderij zijn indicatoren opgenomen die het energiegebruik weergeven per productie-eenheid (hectare cultuurgrond en kg melk) en naar energiedrager (stroom, gas en diesel). Voor de melkveehouderij is de broeikasgasemissie per kg afgeleverde melk opgenomen. De broeikasgasemissie is gebaseerd op alle schakels in de keten, dat wil zeggen inclusief de toeleverende en verwerkende schakels in de keten (cradle-to-gate). Dit is een bewuste keuze: de toeleverende schakel wordt meegenomen om te voorkomen dat de emissies afgewenteld kunnen worden op andere sectoren, met name als melkveehouders de voerproductie uitbesteden. De gehanteerde definitie voor de broeikasgasemissie is gelijk aan de definitie die wordt gehanteerd in de Duurzame Zuivelketen.

Box 4.1 Energie-efficiëntie en broeikasgasemissie per $\mathrm{kg}$ afgeleverde melk maken onderdeel uit van de samengestelde effectindicator

Klimaat en energie is een thema waar veel duidelijke doelen zijn gesteld, op mondiaal, nationaal en sectorniveau. De indicatoren zijn daarom opgenomen in de samengestelde effectindicator voor de melkveehouderij en de akkerbouw (zie hoofdstuk 6).

\section{Akkerbouw}

Het overgrote deel van het energiegebruik op de akkerbouwbedrijven bestaat uit het gebruik van diesel. In 2015 werd er zo'n 7 GJ per hectare gebruikt op akkerbouwbedrijven in Zuid-Holland (figuur 4.1). Tussen de jaren fluctueert het verbruik onder andere door verschillen in bodemomstandigheden tijdens de teeltwerkzaamheden of de weersomstandigheden waardoor de frequentie van beregening of het uitvoeren van gewasbescherming verschilt. Het elektriciteitsverbruik bedroeg in 2015 bijna 2 GJ per hectare (figuur 4.2). Elektriciteit wordt vooral gebruikt na de oogst voor het verwerken en bewaren van producten. Het energieverbruik van de akkerbouwbedrijven in Zuid-Holland, schommelt rond het landelijke verbruik (figuur 4.3).

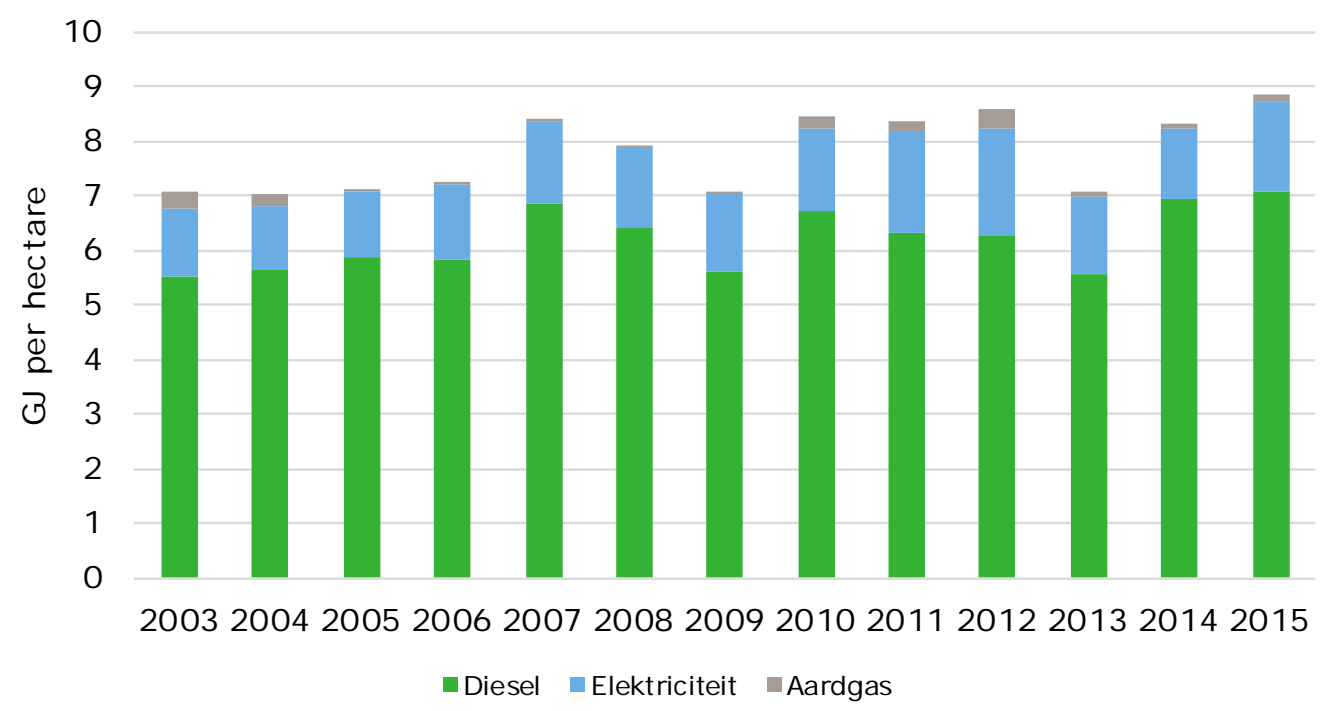

Figuur 4.1 Energiegebruik per ha naar energiedrager op akkerbouwbedrijven in Zuid-Holland Bron: Bedrijveninformatienet, Wageningen Economic Research. 


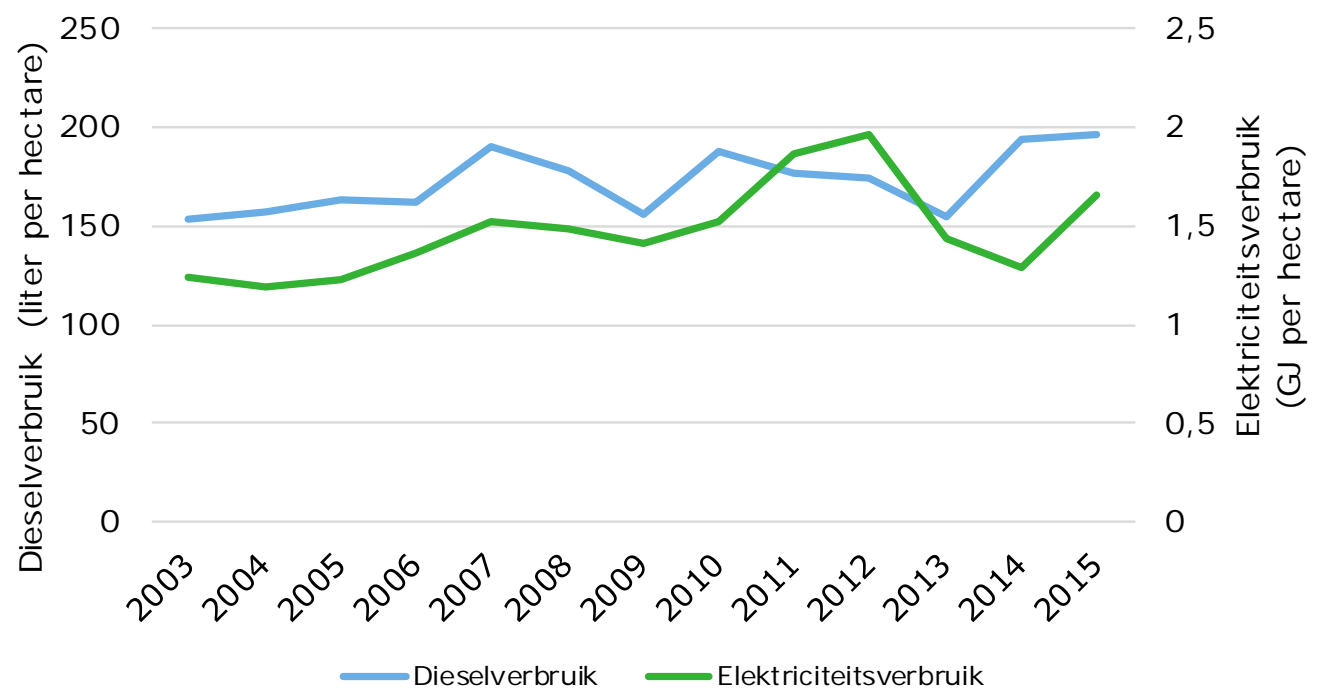

Figuur 4.2 Diesel- en elektriciteitsverbruik per ha op akkerbouwbedrijven in Zuid-Holland Bron: Bedrijveninformatienet, Wageningen Economic Research.

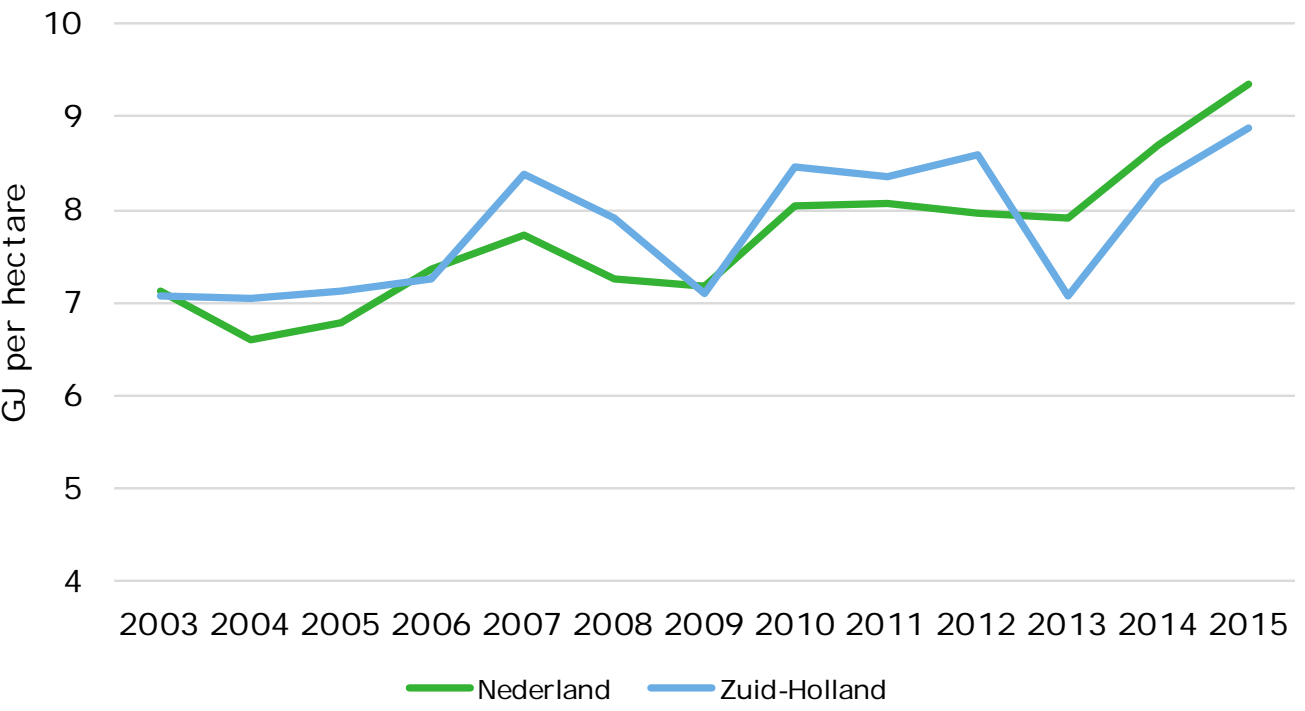

Figuur 4.3 Energiegebruik per hectare op akkerbouwbedrijven Bron: Bedrijveninformatienet, Wageningen Economic Research.

\section{Melkveehouderij}

Melkveebedrijven in Zuid-Holland hebben een hogere broeikasgasemissie per kg afgeleverde melk dan het Nederlands gemiddelde. De broeikasgasemissie van Zuid-Hollandse melkveebedrijven bedroeg over de periode 2013-2015 gemiddeld 1,46 kg CO 2 equivalenten per $\mathrm{kg}$ afgeleverde melk (figuur 4.4). De methaanemissie uit pens- en darmfermentatie en lachgasemissie uit de bodem leveren de grootste bijdrage aan de broeikasgasemissies in de melkveehouderij. 


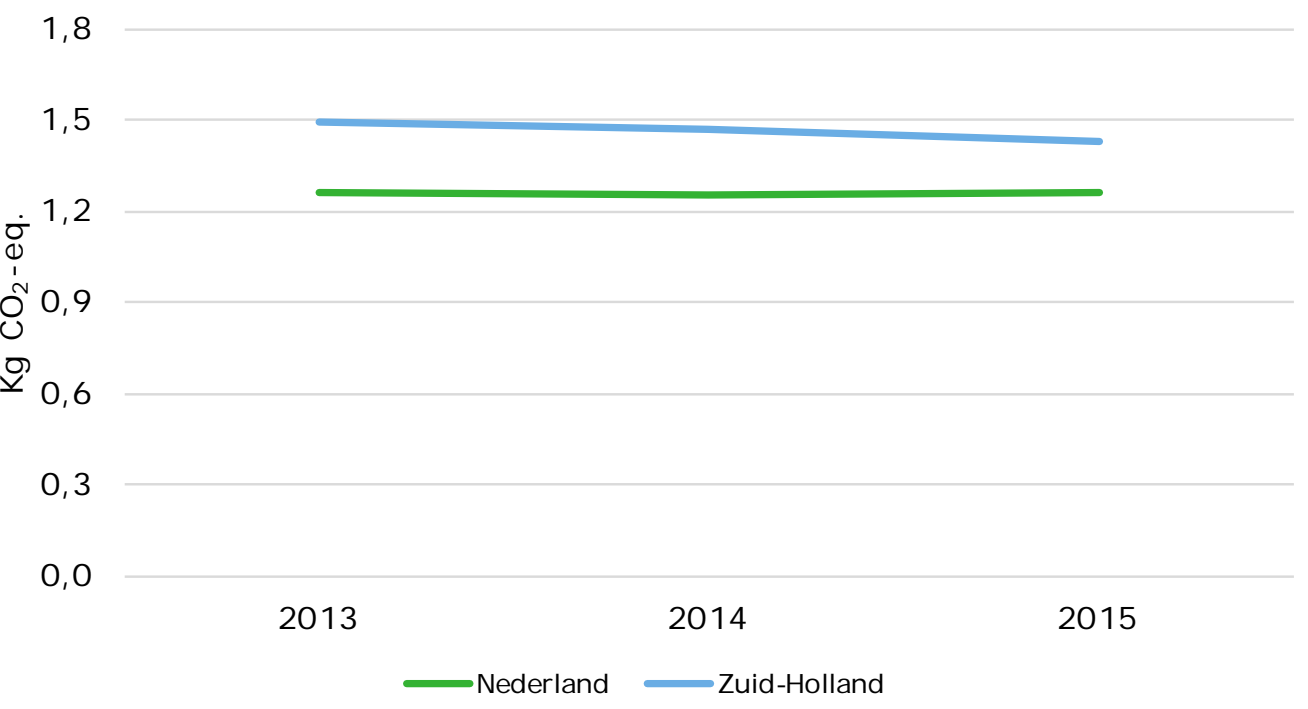

Figuur 4.4 Cradle-to-farm gate broeikasgasemissie per $\mathrm{kg}$ afgeleverde melk op melkveebedrijven Bron: Bedrijveninformatienet, Wageningen Economic Research.

De Zuid-Hollandse melkveebedrijven hebben een hoger aandeel gras in het rantsoen, hetgeen resulteert in een hogere methaanemissie per kg melk. Lachgasemissie uit de bodem vindt voornamelijk plaats op veengronden. In Zuid-Holland zijn relatief meer veengronden aanwezig dan in de rest van Nederland, waardoor de emissie van Zuid-Holland structureel boven de emissie van de rest van Nederland zit. De broeikasgasemissie op melkveebedrijven in Zuid-Holland daalde met circa 100 gram $\mathrm{CO}_{2}$ equivalenten. Dat wordt in belangrijke mate verklaard door een afname van het direct energiegebruik (figuur 4.5).

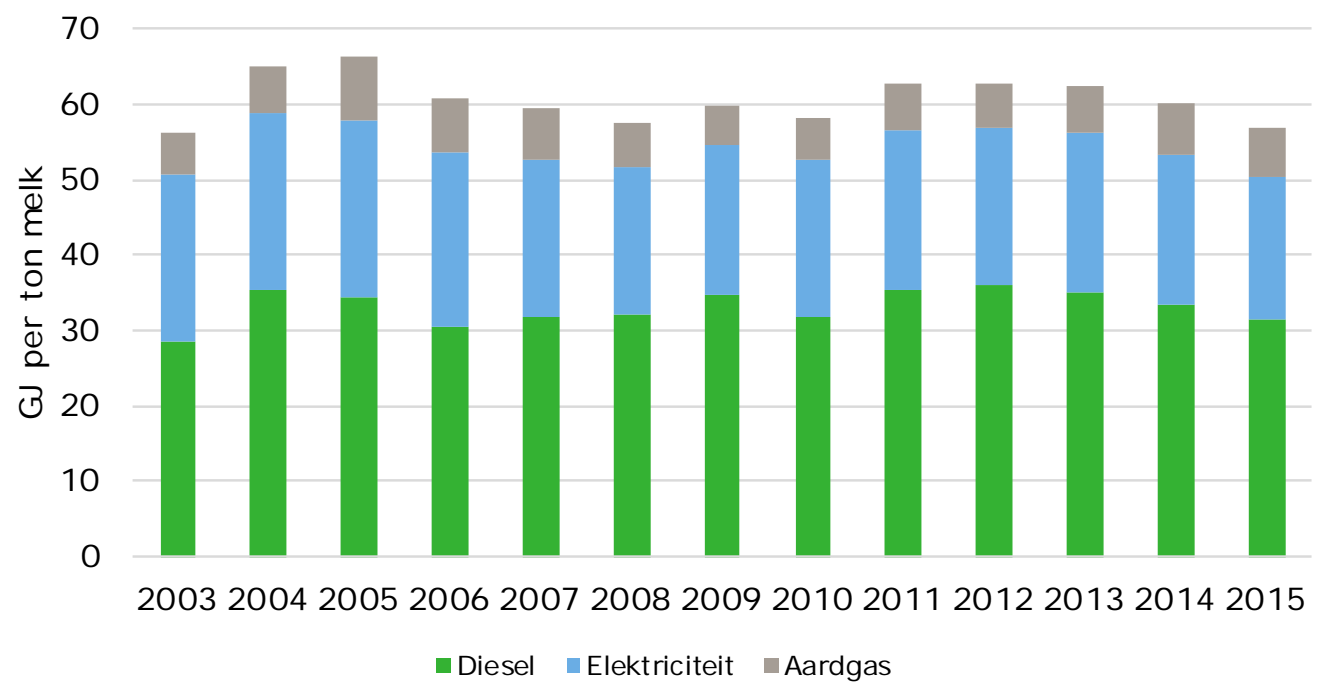

Figuur 4.5 Energiegebruik per ton melk naar energiedrager op melkveebedrijven in Zuid-Holland Bron: Bedrijveninformatienet, Wageningen Economic Research.

Op een gemiddeld melkveebedrijf in de provincie Zuid-Holland werd in 201557 GJ per ton melk gebruikt. Daarmee daalt het energiegebruik op melkveebedrijven in Zuid-Holland voor het vijfde jaar op rij en is het vergelijkbaar met het energiegebruik in het jaar 2003. De daling in energiegebruik per ton melk vond plaats bij zowel het diesel- als elektriciteitsverbruik (figuur 4.6), maar ligt ten opzichte van 2003 alleen bij elektriciteit lager. Het energiegebruik per $100.000 \mathrm{~kg}$ melk van melkveebedrijven in Zuid-Holland is lager dan het Nederlandse gemiddelde (figuur 4.7). De verklaring ligt in belangrijke 
mate in het lagere dieselverbruik door een hoog aandeel grasland in het bouwplan en een extensievere bedrijfsvoering in met name de veenweideregio.

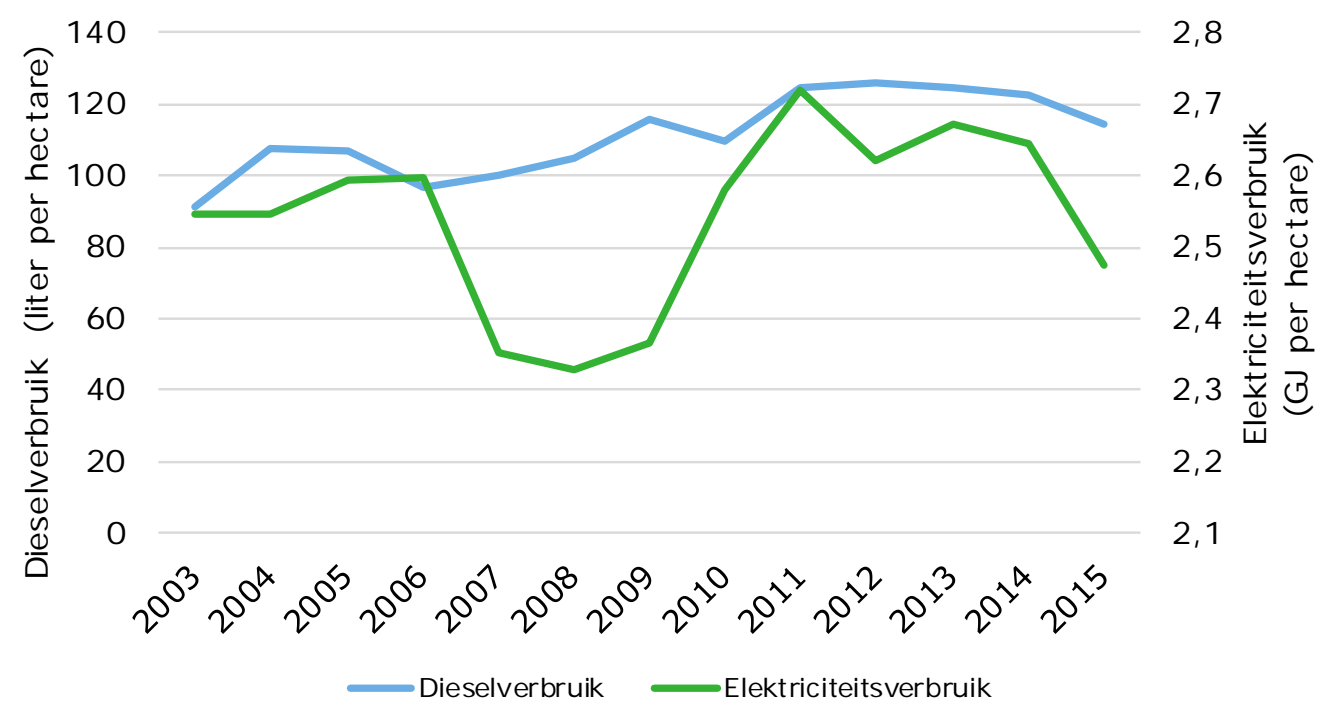

Figuur 4.6 Diesel- en elektriciteitsverbruik per ha op melkveebedrijven in Zuid-Holland Bron: Bedrijveninformatienet, Wageningen Economic Research.

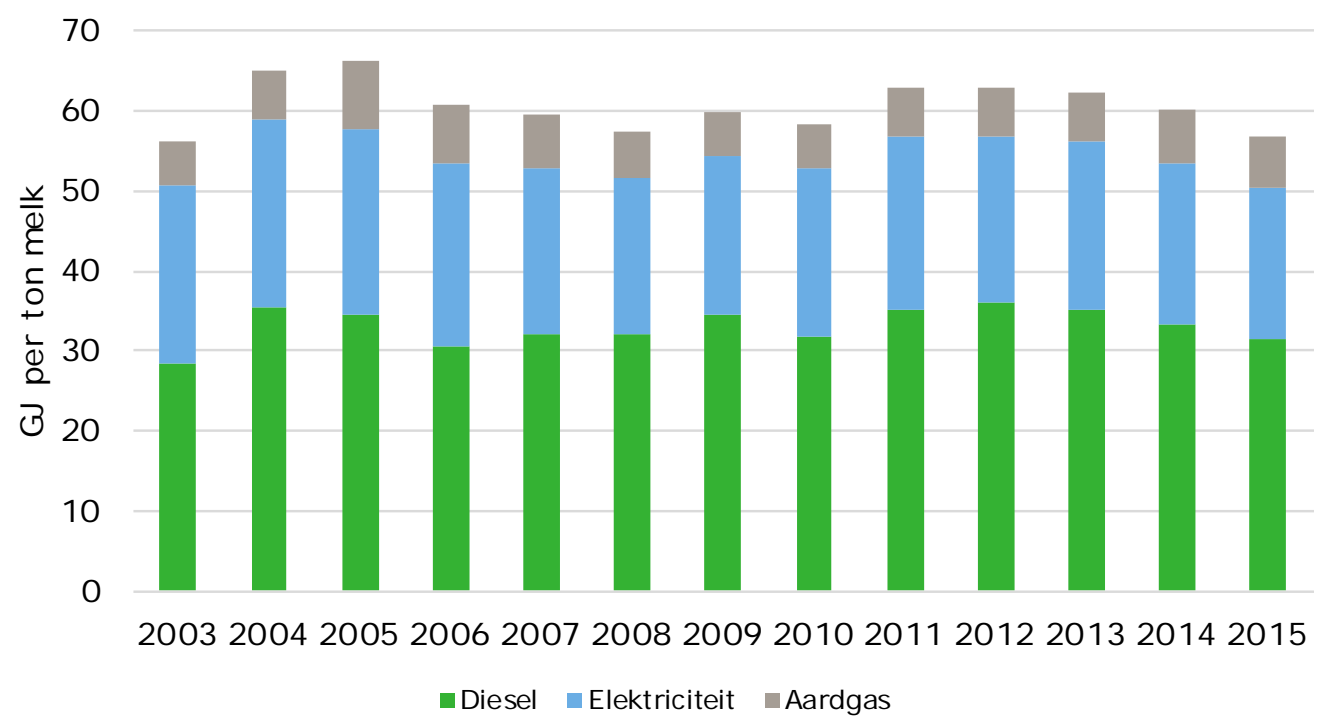

Figuur 4.7 Energiegebruik per ton melk op melkveebedrijven Bron: Bedrijveninformatienet, Wageningen Economic Research.

\section{Doelen op gebied van energie en klimaat}

Er zijn diverse doelstellingen om de broeikasgasemissie te verminderen (Kyoto-protocol, Convenant Schone en zuinige agrosectoren). De zuivelketen heeft zich via de Duurzame Zuivelketen als doel gesteld om de broeikasgasemissie uit de zuivelketen in 2020 te reduceren met $20 \%$ ten opzichte van 1990, en daarnaast het doel van een klimaatneutrale groei ten opzichte van 2011. Ook voor energie zijn er doelstellingen gemaakt door de Duurzame Zuivelketen. Het doel van de Duurzame Zuivelketen is een verbetering van de energie-efficiëntie van de zuivelketen van gemiddeld $2 \%$ per jaar in 2005 2020. In de sectorrapportage van de Duurzame Zuivelketen wordt jaarlijks gerapporteerd over de voortgang (Reijs et al., 2016). 


\subsection{Mestgebruik en - overschot}

\section{Definitie van gehanteerde indicatoren}

Voor dit thema wordt gebruik gemaakt van indicatoren die gebruikt worden in het Landelijk Meetnet effecten Mestbeleid (LMM). LMM is een integraal monitoringsprogramma met als doel het volgen en vastleggen van de effecten van het mestbeleid op de bedrijfsvoering en (grond)waterkwaliteit op Nederlandse landbouwbedrijven. Belangrijke doelvariabele daarbij is het monitoren van de bodembalans. De bodembalans, ook wel bodemoverschot genoemd, is de bedrijfsbalans inclusief de aanvoer via mineralisatie, depositie en fixatie en de afvoer via gasvormige emissies. Deze wordt uitgedrukt in de hoeveelheid stikstof of fosfaat per hectare cultuurgrond. De indicator geeft aan wat het 'overschot' aan deze mineralen is als je alle inputs verminderd met alle outputs van het boerenbedrijf. Op basis van de Emissieregistratie wordt de cumulatieve ammoniakemissie uit de melkveehouderij gemonitord. De emissieregistratie is de bron waarmee de landelijk emissies (waaronder ammoniak) worden gemonitord.

Box 4.2 Stikstofbodemoverschot en fosfaatoverschot per hectare cultuurgrond maken onderdeel uit van de samengestelde effectindicator

De emissie van en de uit- en afspoeling van stikstof en fosfaat hebben een effect op bodem-, water en luchtkwaliteit in termen van vermesting en verzuring. Vanuit Nationale en Europese wetgeving zijn er doelen gesteld om deze kwaliteit te verbeteren. Vanaf 2015 worden in Nederland fosfaatgebruiksnormen toegepast die zijn gebaseerd op evenwichtsbemesting. Voor dierlijke mest heeft Nederland derogatie aangevraagd. Dit betekent dat, onder bepaalde voorwaarden, op melkveebedrijven meer dierlijke mest kan worden gebruikt dan de algemeen geldende Europese richtlijn. Een belangrijke voorwaarde aan de derogatie is, dat minimaal $80 \%$ van de oppervlakte landbouwgrond in de periode 15 mei tot en met 15 september onafgebroken met gras wordt beteeld (zie ook Box 2.1 in paragraaf 2.1 over wetgeving rond groei van de melkveestapel). Het stikstofbodemoverschot en het fosfaatoverschot zijn opgenomen in de samengestelde effectindicator voor de akkerbouw en de melkveehouderij (zie hoofdstuk 6).

\section{Akkerbouw}

Het stikstof bodemoverschot op akkerbouwbedrijven in Zuid-Holland is de laatste jaren stabiel rond de $120 \mathrm{~kg} \mathrm{~N}$ per hectare (figuur 4.8 en 4.9). In het verleden lagen de overschotten op een hoger niveau. Door wettelijke maatregelen (MINAS en gebruiksnormen) namen de overschotten af. Het grootste deel van de bemesting bestaat uit kunstmest, in 2015 twee derde van de totale aanvoer. De stikstofgift wordt aangevuld met dierlijke mest en een klein deel andere organische meststoffen.

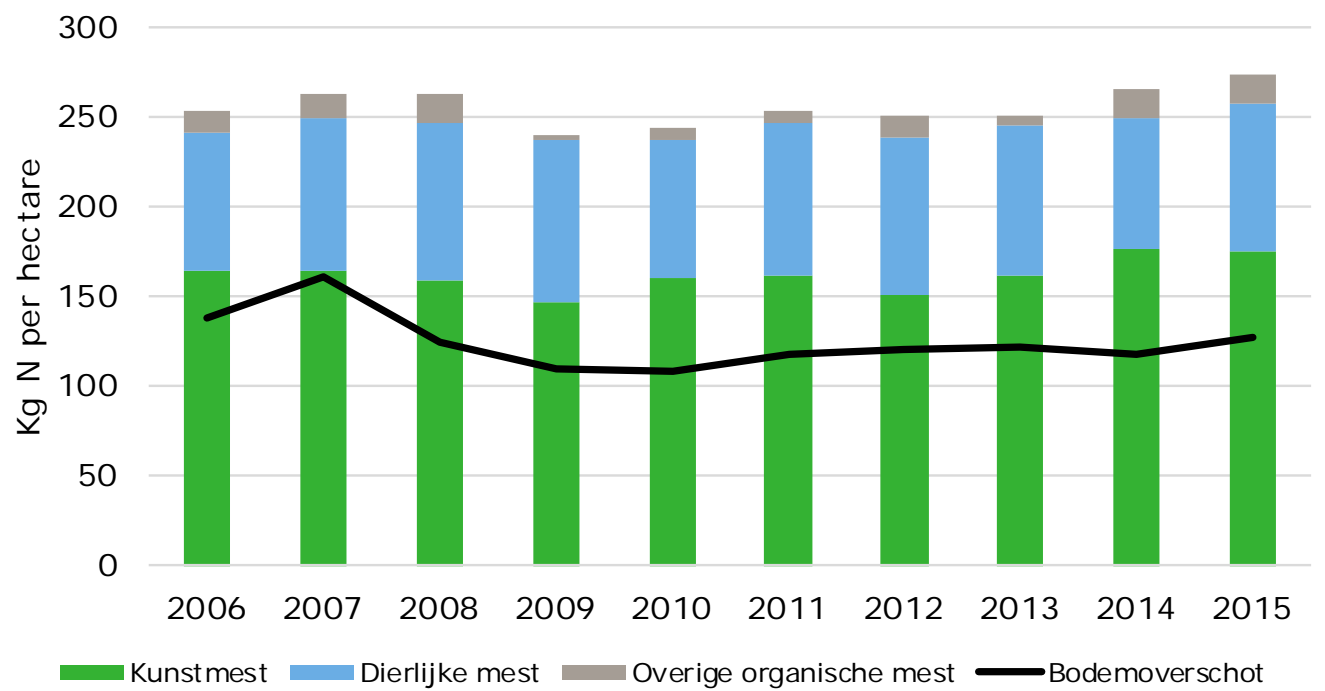

Figuur 4.8 Stikstofbodemoverschot en bemesting per hectare op akkerbouwbedrijven in Zuid-Holland Bron: Bedrijveninformatienet, Wageningen Economic Research. 


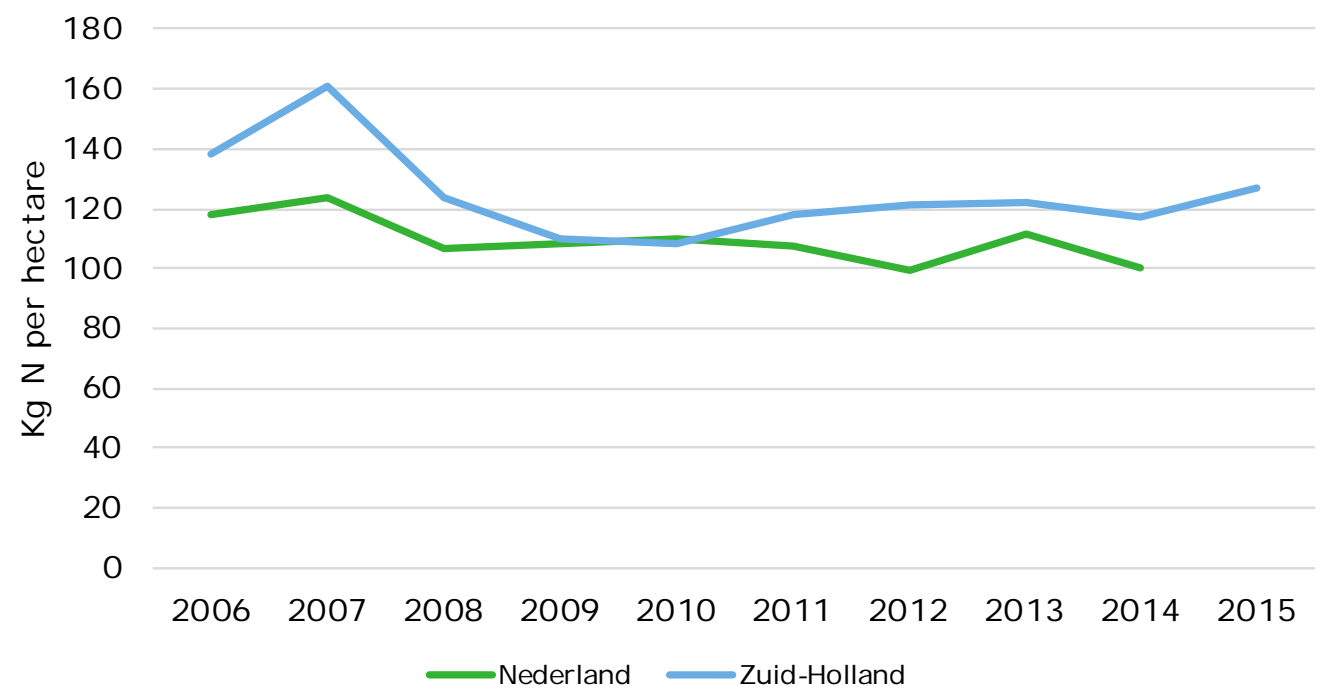

Figuur 4.9 Stikstofbodemoverschot per hectare op akkerbouwbedrijven a) Bron: Bedrijveninformatienet, Wageningen Economic Research.

Voetnoot: De gegevens voor het Nederlands totaal in 2015 zijn nog niet beschikbaar.

Het fosfaatbodemoverschot is sterk teruggelopen sinds 2006 (figuur 4.10). Bedroeg het overschot in 2006 nog meer dan $35 \mathrm{~kg}$ per hectare, in 2015 was dit nog $1 \mathrm{~kg}$. De afname wordt veroorzaakt doordat fosfaatkunstmeststoffen ook onder de gebruiksnormen vallen. Daardoor nam het kunstmestverbruik ook af. In Zuid-Holland is het overschot over het algemeen lager dan gemiddeld in Nederland (figuur 4.11). Fosfaat wordt hoofdzakelijk aangevoerd in de vorm van dierlijke mest.

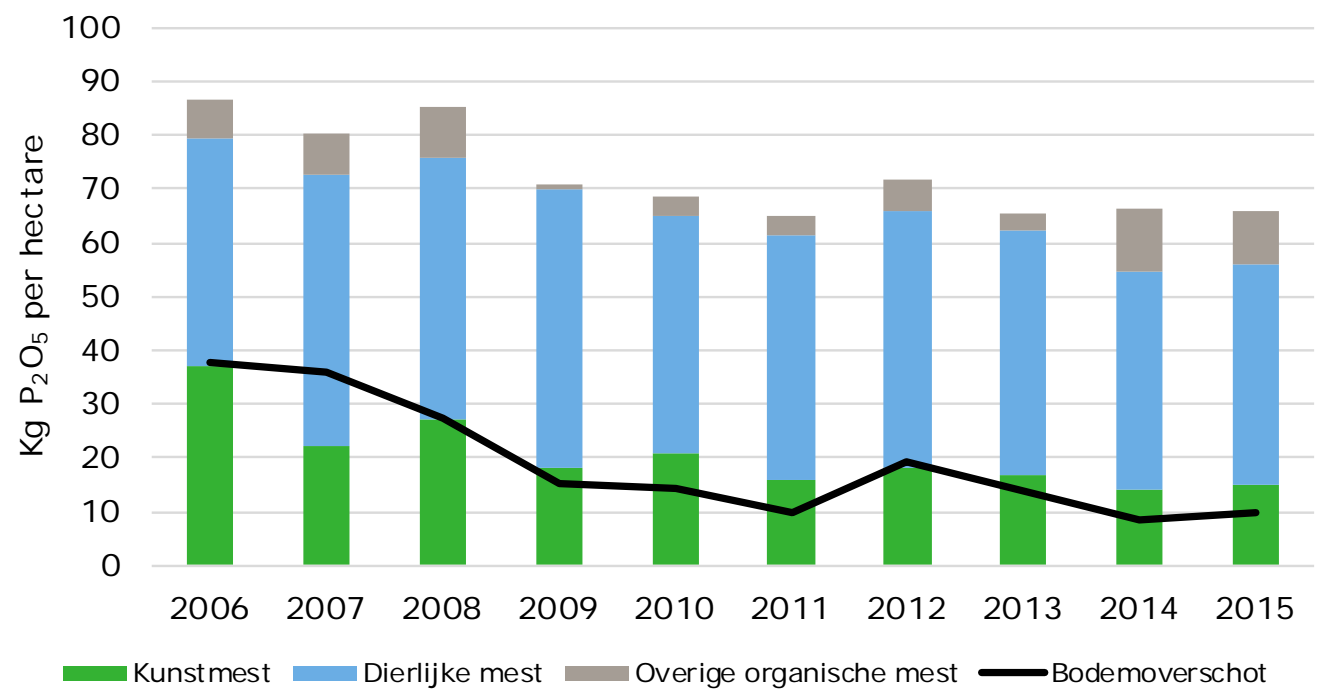

Figuur 4.10 Fosfaatbodemoverschot en bemesting per hectare op akkerbouwbedrijven in Zuid-Holland Bron: Bedrijveninformatienet, Wageningen Economic Research. 


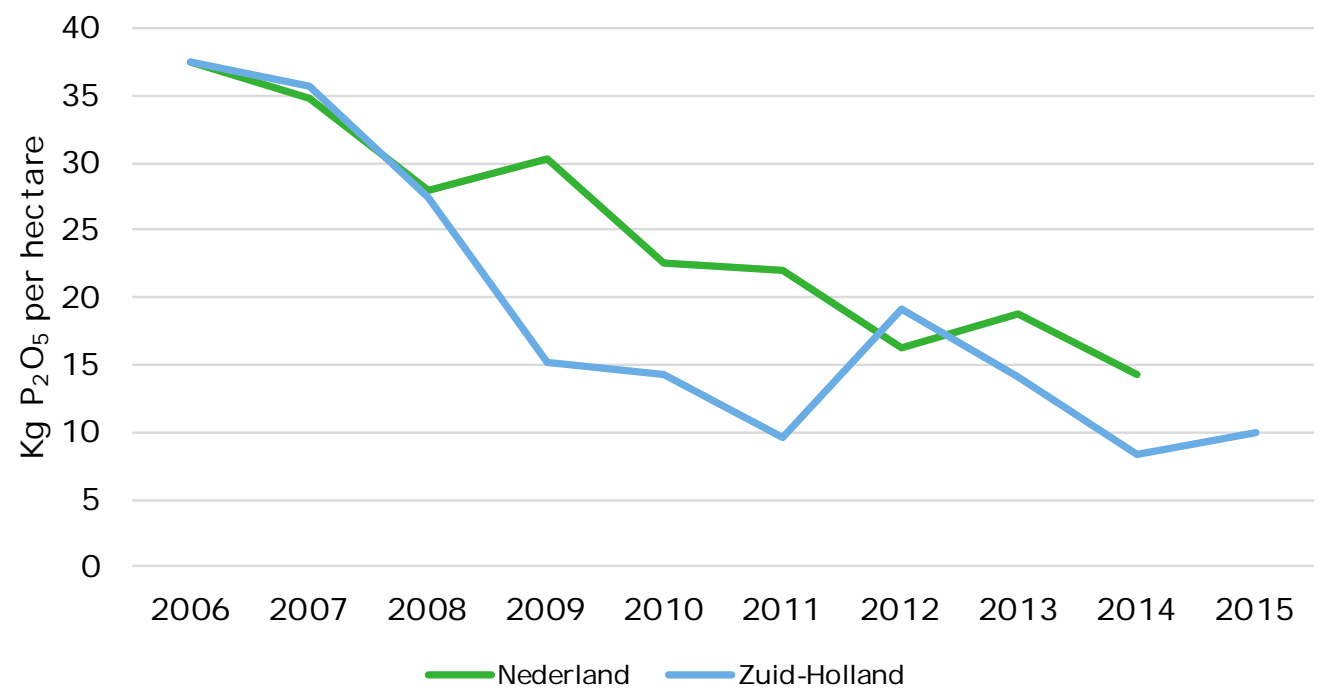

Figuur 4.11 Fosfaat bodemoverschot per hectare op akkerbouwbedrijven a) a) De gegevens voor het Nederlands totaal in 2015 zijn nog niet beschikbaar. Bron: Bedrijveninformatienet, Wageningen Economic Research.

\section{Melkveehouderij}

Sinds 2014 is er een negatief fosfaatoverschot op een groeiend aantal melkveebedrijven in ZuidHolland (figuur 4.12). Reden van het negatieve overschot is de toename van fosfaatafvoer via afvoer van organische mest en van dierlijke producten (zoals melk) bij een gelijkblijvende aanvoer van fosfaat. Het gebruik van fosfaatkunstmest is sinds 2006 flink teruggelopen door de introductie van het stelsel van gebruiksnormen. Vanaf 2014 is het voor bedrijven die deelnemen aan de derogatie, verboden om fosfaatkunstmest te gebruiken. De ontwikkeling in het fosfaatoverschot is vergelijkbaar met het Nederlands gemiddelde (figuur 4.13).

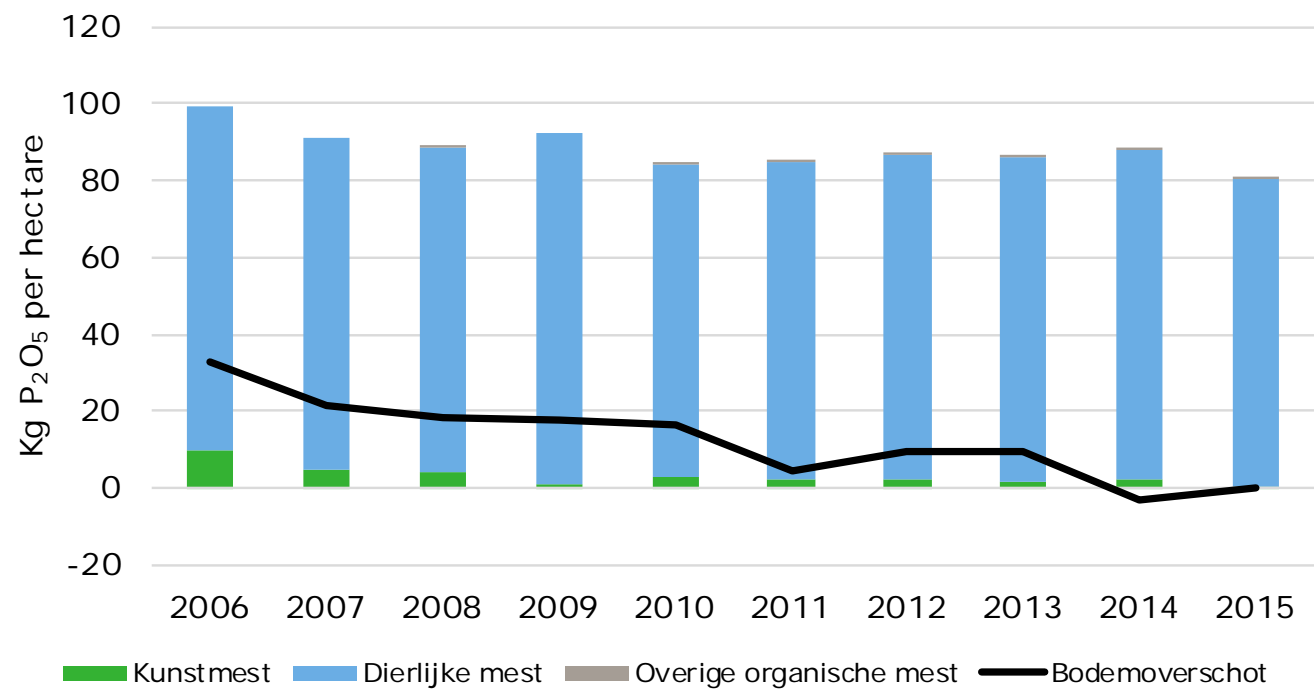

Figuur 4.12 Fosfaatbodemoverschot en bemesting per hectare op melkveebedrijven in Zuid-Holland Bron: Bedrijveninformatienet, Wageningen Economic Research. 


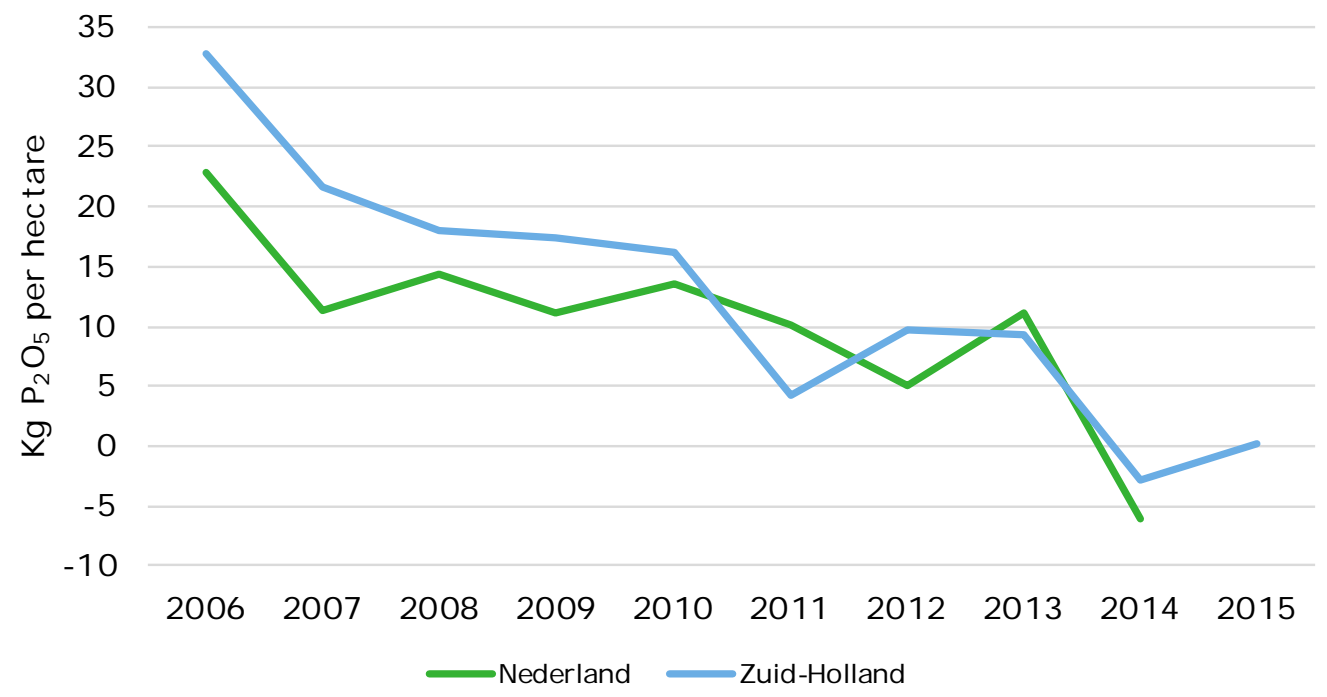

Figuur 4.13 Fosfaat bodemoverschot per hectare op melkveebedrijven Bron: Bedrijveninformatienet, Wageningen Economic Research.

Doordat er in Zuid-Holland relatief veel veengrond aanwezig is, komt de bodembalans hoger uit dan het Nederlands gemiddelde (figuur 4.14). De bodembalans is de bedrijfsbalans inclusief de aanvoer via mineralisatie, depositie en fixatie en de afvoer via gasvormige emissies. Bij veengrond vindt er mineralisatie plaats, waardoor bedrijven op veen een hoger bodemoverschot hebben. Een hoger bodemoverschot betekent echter nog niet een hogere uitspoeling van nitraat. De nitraatuitspoeling op grasland is namelijk lager dan op bouwland. Bedrijven in Zuid-Holland hebben een relatief groot aandeel grasland in het bouwplan. Het hogere aandeel grasland in het bouwplan zorgt eveneens voor een hoger stikstofgebruik (figuur 4.15). Zowel in Zuid-Holland en het Nederlands gemiddelde stijgt het stikstofgebruik per ha. Deels wordt dit verklaard door de gunstigere groeiomstandigheden in 2014 maar ook door intensivering van bedrijven. Derogatiebedrijven die mest moeten afvoeren om binnen de fosfaatgebruiksruimte te blijven, houden bij stikstof een stuk gebruiksruimte over die kan worden opgevuld. Dat wordt in bedrijven in Zuid-Holland vaker gedaan met kunstmest dan met de aanvoer van dierlijke mest uit de intensieve veehouderij, die beperkt in de regio voorhanden is.

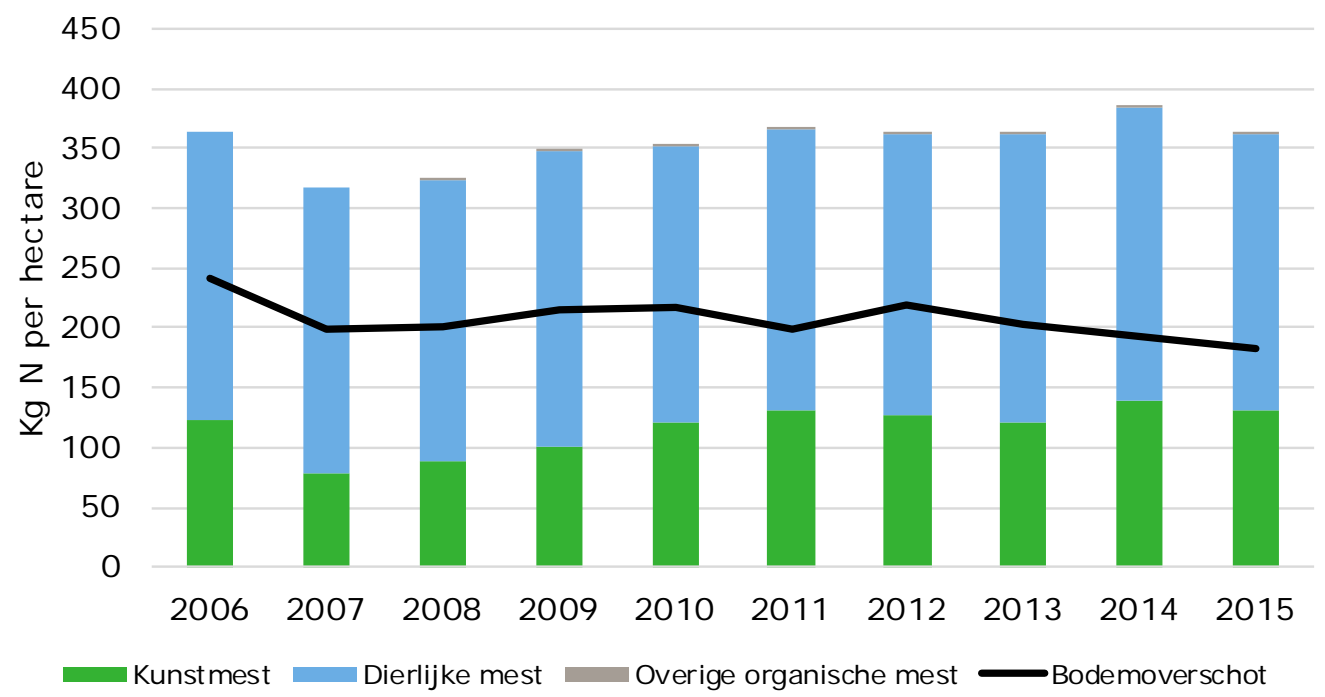

Figuur 4.14 Stikstofbodemoverschot en bemesting per hectare op melkveebedrijven in Zuid-Holland Bron: Bedrijveninformatienet, Wageningen Economic Research. 


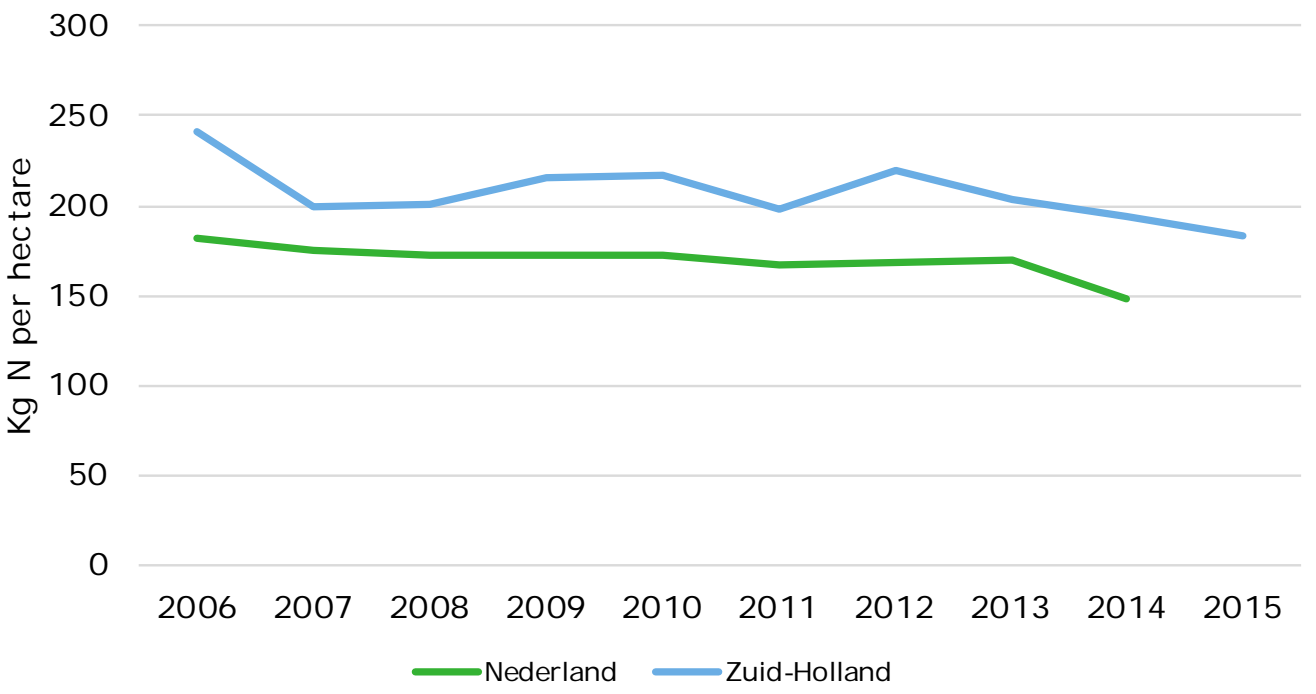

Figuur 4.15 Stikstof bodemoverschot per hectare op melkveebedrijven Bron: Bedrijveninformatienet, Wageningen Economic Research.

\section{Ammoniakemissie uit de melkveehouderij}

De ammoniakemissie in de melkveehouderij in Zuid-Holland stijgt sinds 2013. Dit komt door een stijging van het aantal dieren en een hogere stikstofexcretie per dier per jaar. Het grootste gedeelte van de ammoniakemissie vindt plaats bij de aanwending (60\%) en uit stal en opslag (37\%). De bijdrage door weidegang is beperkt ( $3 \%)$. Ruim driekwart van de emissie is afkomstig van melkkoeien, de rest van jongvee.

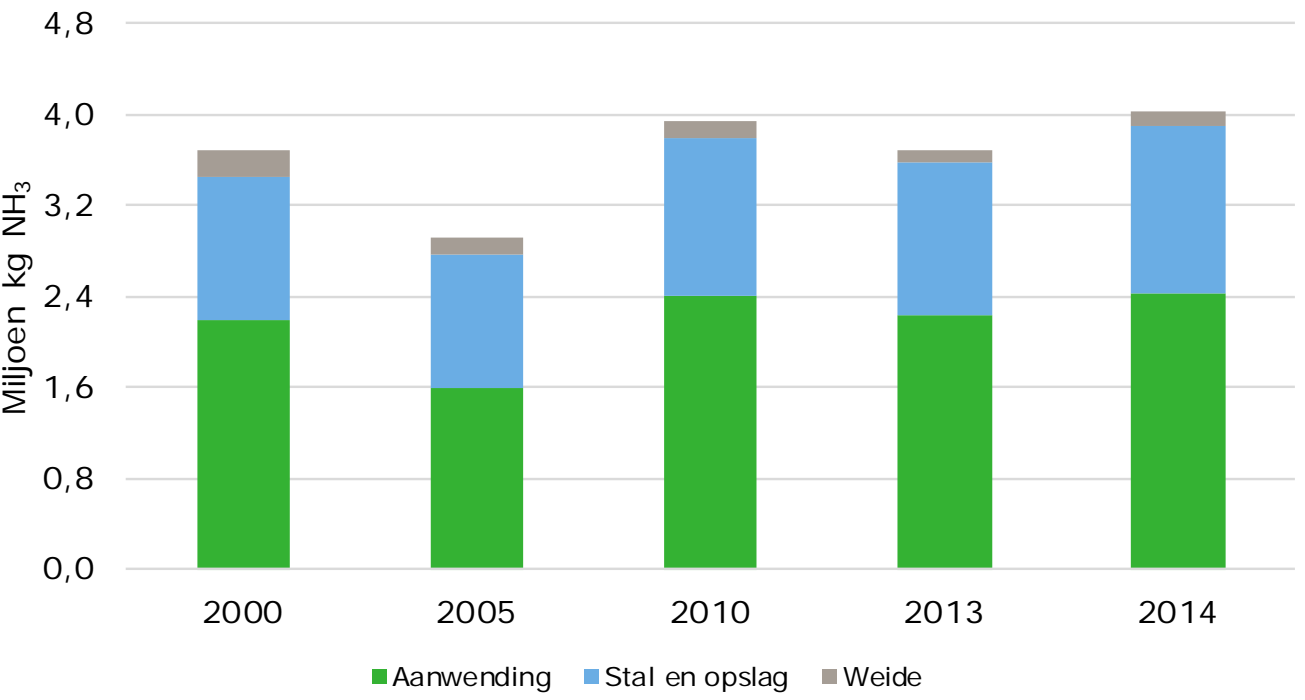

Figuur 4.16 Ammoniakemissie uit de melkveehouderij in Zuid-Holland Bron: Emissieregistratie.nl, bewerking Wageningen Economic Research.

Eind vorige eeuw is een grote emissiereductie gerealiseerd door emissiearmere aanwending en krimp van de melkveestapel. In 2014 emitteerde in Zuid-Holland ruim miljoen kg ammoniak uit mest van melkkoeien en jongvee voor de melkveehouderij (figuur 4.16). Ondanks een lagere emissie door beweiding, lagere stikstofbemestingsniveaus en het verbod op het aanwenden van mest op bouwland in twee werkgangen, steeg de ammoniakemissie door de forse toename in het aantal melkkoeien sinds 2005 (zie paragraaf 2.1). 
De provincie Zuid-Holland is onder meer verantwoordelijk voor de programmatische aanpak voor Stikstof (PAS). De Wet Ammoniak en Veehouderij (WAV) bepaalt of aanpassingen of uitbreiding van een veehouderijbedrijf kunnen worden goedgekeurd. De Wet Ammoniak en Veehouderij heeft als doel om zeer kwetsbare gebieden te beschermen tegen ammoniakuitstoot afkomstig van de veehouderij. Dit zijn natuurgebieden die voor verzuring gevoelig zijn en binnen het Natuur Netwerk Nederland (NNN) liggen. Op de website van de PAS is meer gebied specifieke informatie te vinden. De provincie Zuid-Holland maakt echter geen gebruik van de mogelijkheid om kwetsbare gebieden aan te wijzen.

De bijdrage van de provincie Zuid-Holland aan de ammoniakemissie uit de veehouderij in Nederland bedraagt overigens circa 6\% (Emissieregistratie. $\mathrm{nl}$ ).

\subsection{Gewasbescherming}

\section{Definitie van gehanteerde indicatoren}

Voor het thema gewasbescherming wordt gebruik gemaakt van twee indicatoren: het middelengebruik per hectare cultuurgrond en de milieubelasting per hectare cultuurgrond. Met de eerste indicator wordt inzicht gegeven in met middelgebruik, gemeten in hoeveelheden werkzame stof naar middelengroep (herbiciden, insecticiden, fungiciden, nematiciden en overige middelen). De tweede indicator geeft inzicht in de milieubelasting van deze middelen voor de compartimenten bodem, oppervlakte- en grondwater.

\section{Box 4.3 Milieubelastingspunten per hectare cultuurgrond maakt onderdeel uit van de samengestelde effectindicator}

Gewasbeschermingsmiddelen kunnen terechtkomen in de compartimenten bodem, water en lucht. Emissies naar grond- en oppervlaktewater leiden tot problemen bij winning van drinkwater, schadelijke effecten voor waterorganismen en bodemorganismen, en achteruitgang van de biodiversiteit aan vogels en insecten. Daarom is het gebruik van deze middelen aan strenge voorwaarden gebonden. De indicator milieubelastingspunten per hectare is opgenomen in de samengestelde effectindicator voor de akkerbouw (zie hoofdstuk 6).

\section{Akkerbouw}

De akkerbouwbedrijven in Zuid-Holland gebruiken ongeveer evenveel gewasbeschermingsmiddelen ( $\mathrm{kg}$ werkzame stof per hectare) als het gemiddelde akkerbouwbedrijf in Nederland (figuur 4.17 en 4.18). Het gebruik ligt de laatste jaren op een stabiel niveau tussen de 8 en $10 \mathrm{~kg}$ per hectare. Het gewasbeschermingsmiddelengebruik bestaat voornamelijk uit fungiciden en herbiciden. In jaren met vochtige warme zomers neemt het fungiciden verbruik vaak toe doordat het risico van een uitbraak van Phytophthora dan groot is. 


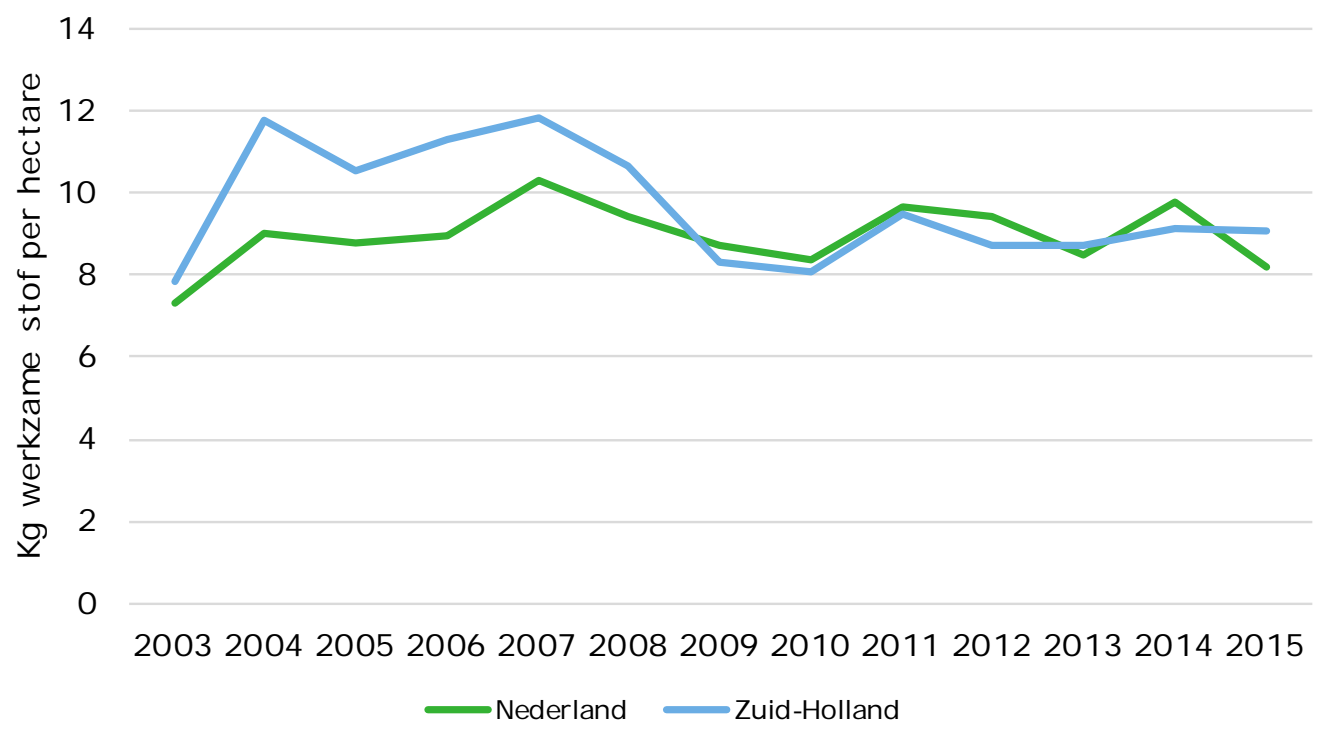

Figuur 4.17 Gewasbeschermingsmiddelengebruik per hectare op akkerbouwbedrijven Bron: Bedrijveninformatienet, Wageningen Economic Research.

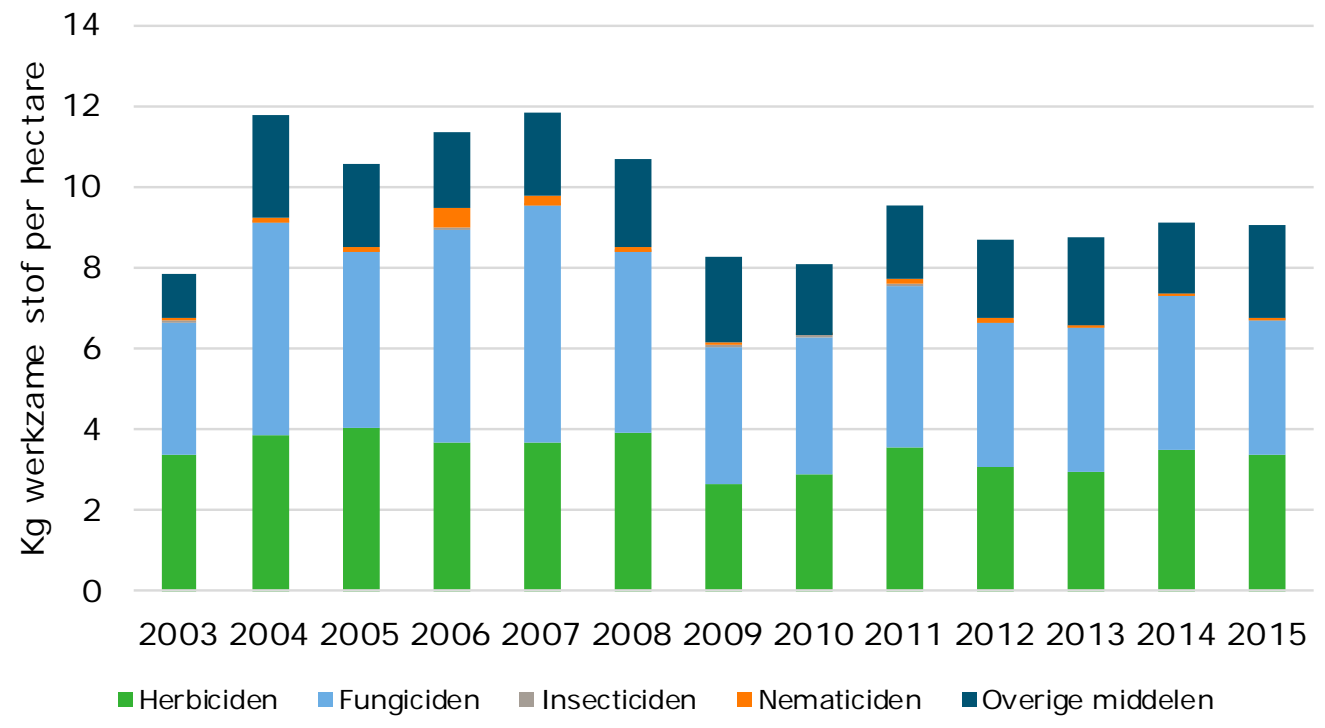

Figuur 4.18 Gewasbeschermingsmiddelengebruik per hectare naar soort op akkerbouwbedrijven in Zuid-Holland

Bron: Bedrijveninformatienet, Wageningen Economic Research.

De milieubelasting neemt wel af (figuur 4.19 en 4.20), omdat er middelen worden gebruikt die minder milieubelastend zijn dan in het verleden. Vooral de milieubelasting richting het oppervlaktewater nam sterk af. Dit wordt veroorzaakt doordat er maatregelen worden genomen om het verwaaien van middelen in het oppervlaktewater (drift) te verminderen, zoals andere spuitdoppen, luchtondersteuning en spuitvrije zones. 


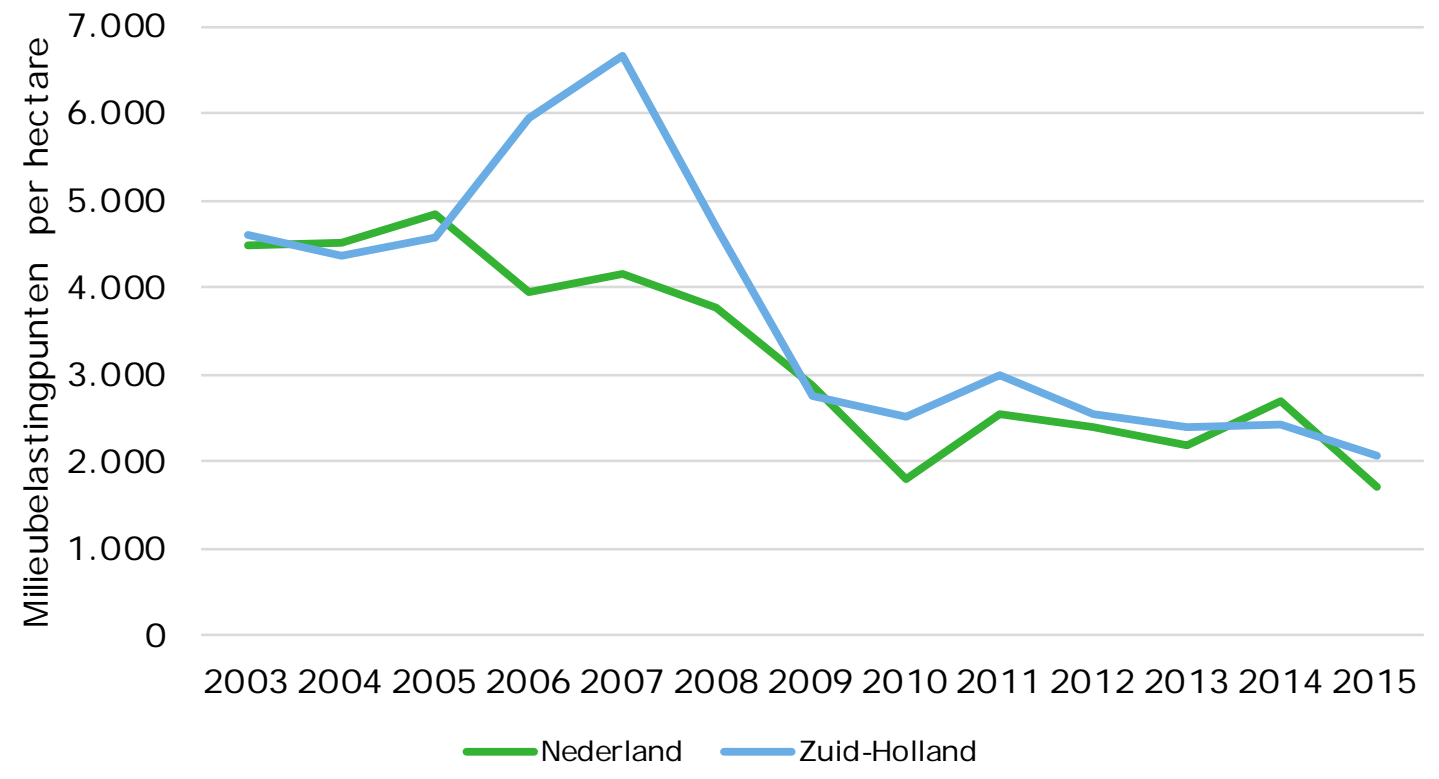

Figuur 4.19 Milieubelastingspunten per hectare op akkerbouwbedrijven Bron: Bedrijveninformatienet, Wageningen Economic Research.

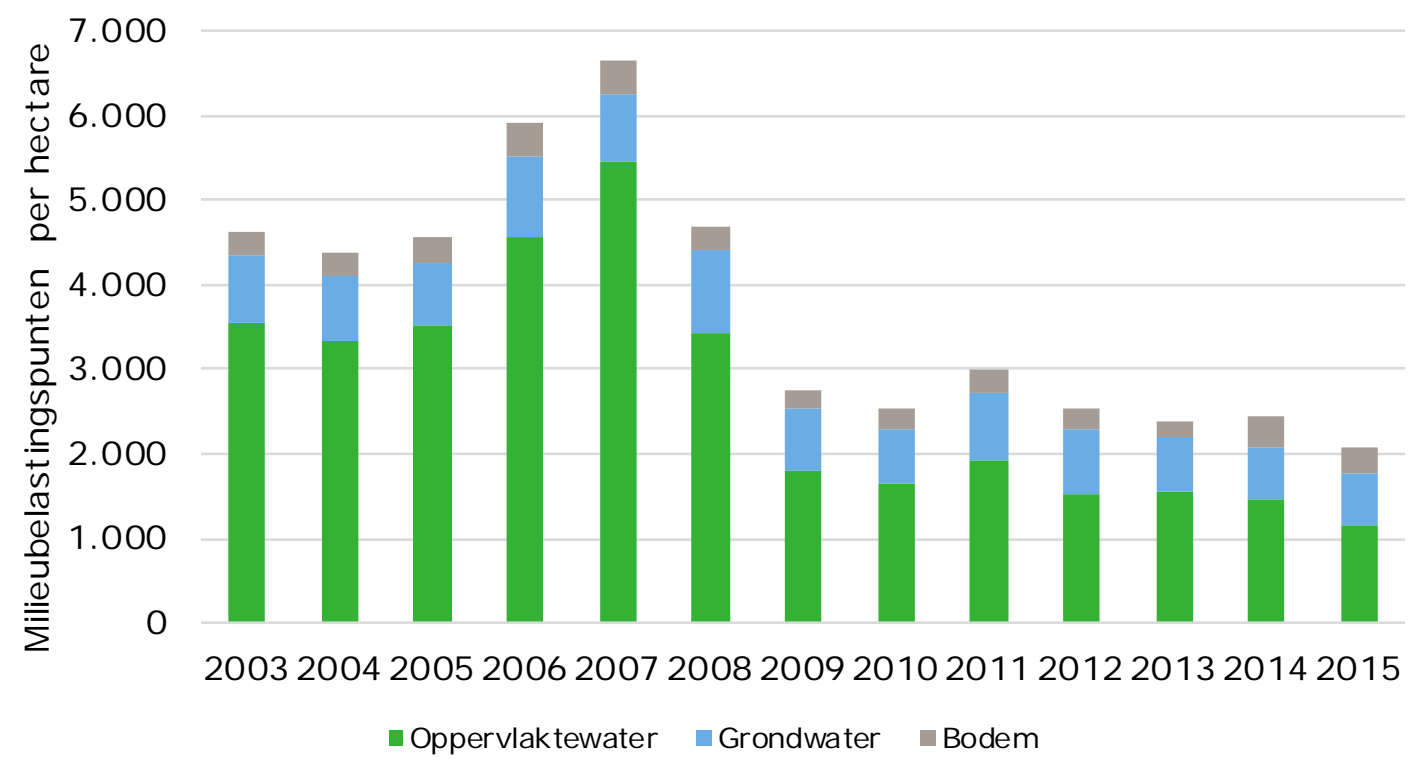

Figuur 4.20 Milieubelastingspunten per hectare naar compartiment op akkerbouwbedrijven in ZuidHolland

Bron: Bedrijveninformatienet, Wageningen Economic Research.

\section{Tweede nota Duurzame Gewasbescherming}

In de Tweede Nota Duurzame Gewasbescherming heeft het ministerie van Economische Zaken de eisen met betrekking tot de emissies van gewasbeschermingsmiddelen aangescherpt. In 2023 dient voor het oppervlaktewater het aantal overschrijdingen van de milieukwaliteitsnormen uit de Kaderrichtlijn Water met 90\% verminderd te zijn ten opzichte van 2013. Sinds 2014 zijn er extra maatregelen verplicht om drift (verwaaien van gewasbeschermingsmiddelen) naar het oppervlaktewater te verminderen. Daarnaast wordt de teeltvrije zone groter. Ook erfemissies moeten worden aangepakt (Agrimatie.nl, 2017). 


\section{Melkveehouderij}

Het gewasbeschermingsmiddelengebruik in de melkveehouderij is in vergelijking met andere sectoren relatief laag. Uit onderstaande figuur blijkt dat het verbruik in kg werkzame stof per hectare in ZuidHolland op een lager niveau ligt dan landelijk (figuur 4.21). Het verschil kan mogelijk worden veroorzaakt doordat op sommige als melkvee getypeerde bedrijven buiten Zuid-Holland ook marktbare gewassen worden verbouwd waarop in verhouding met grasland en voedermais relatief veel gewasbeschermingsmiddelen worden verbruiken. Op melkveebedrijven in Zuid-Holland wordt relatief minder snijmaïs geteeld. Daarnaast wordt er in het veenweidegebied minder grasland gescheurd en opnieuw ingezaaid dan op het gemiddelde melkveebedrijf in Nederland. Het gebruik van gewasbeschermingsmiddelen in de melkveehouderij is veel minder dan bij de akkerbouw. Het totale gebruik op melkveebedrijven is daarentegen wel van belang, omdat de melkveehouderij een groot areaal beslaat in Zuid-Holland.

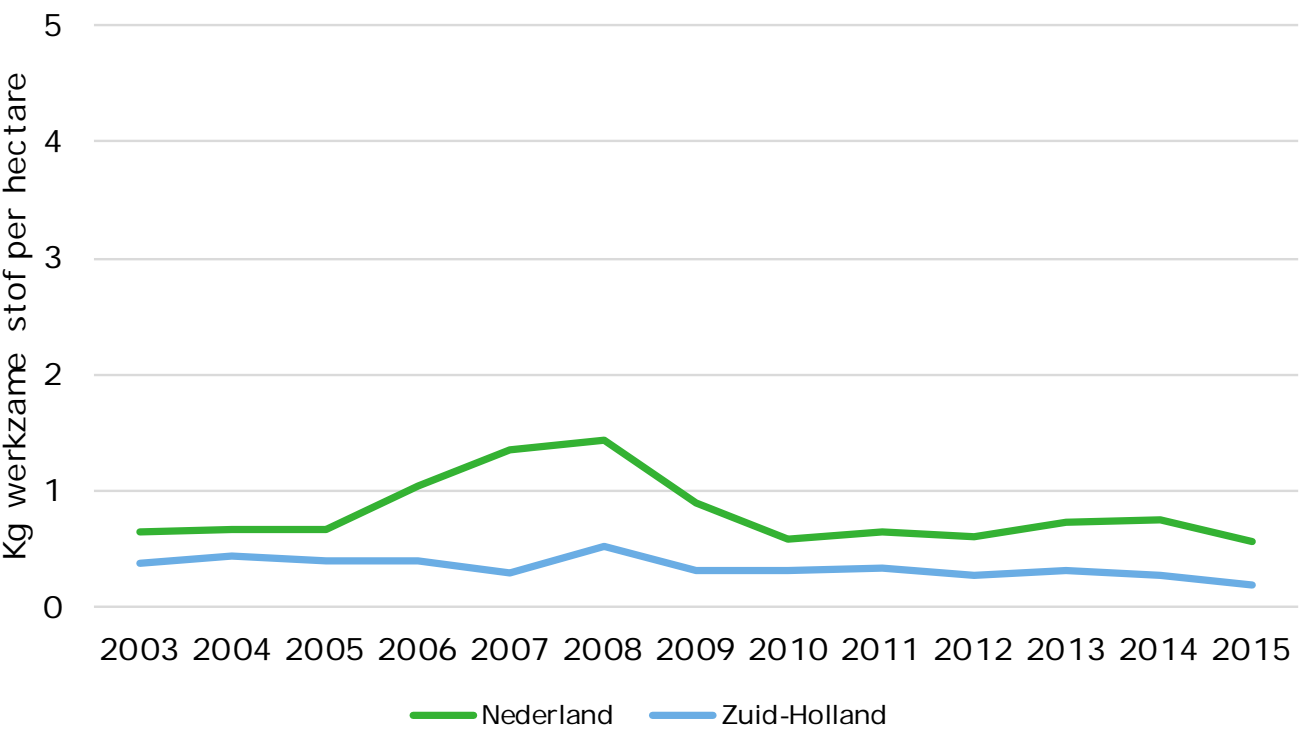

Figuur 4.21 Gewasbeschermingsmiddelengebruik per hectare op melkveebedrijven Bron: Bedrijveninformatienet, Wageningen Economic Research.

Mede door het lager middelenverbruik in Zuid-Holland ligt ook de milieubelasting gemiddeld op een lager niveau dan landelijk (figuur 4.22). In sommige jaren piekt Zuid-Holland maar dit hangt af van de keuze van de middelen die worden gebruikt of door mogelijke steekproefeffecten. Sommige middelen hebben een forse milieubelasting maar zijn wellicht noodzakelijk om te gebruiken gezien de ziektedruk die soms erg weersafhankelijk is. In 2010 is er een grote inzet van insecticiden die in andere jaren in veel mindere mate of soms nauwelijks worden ingezet. 


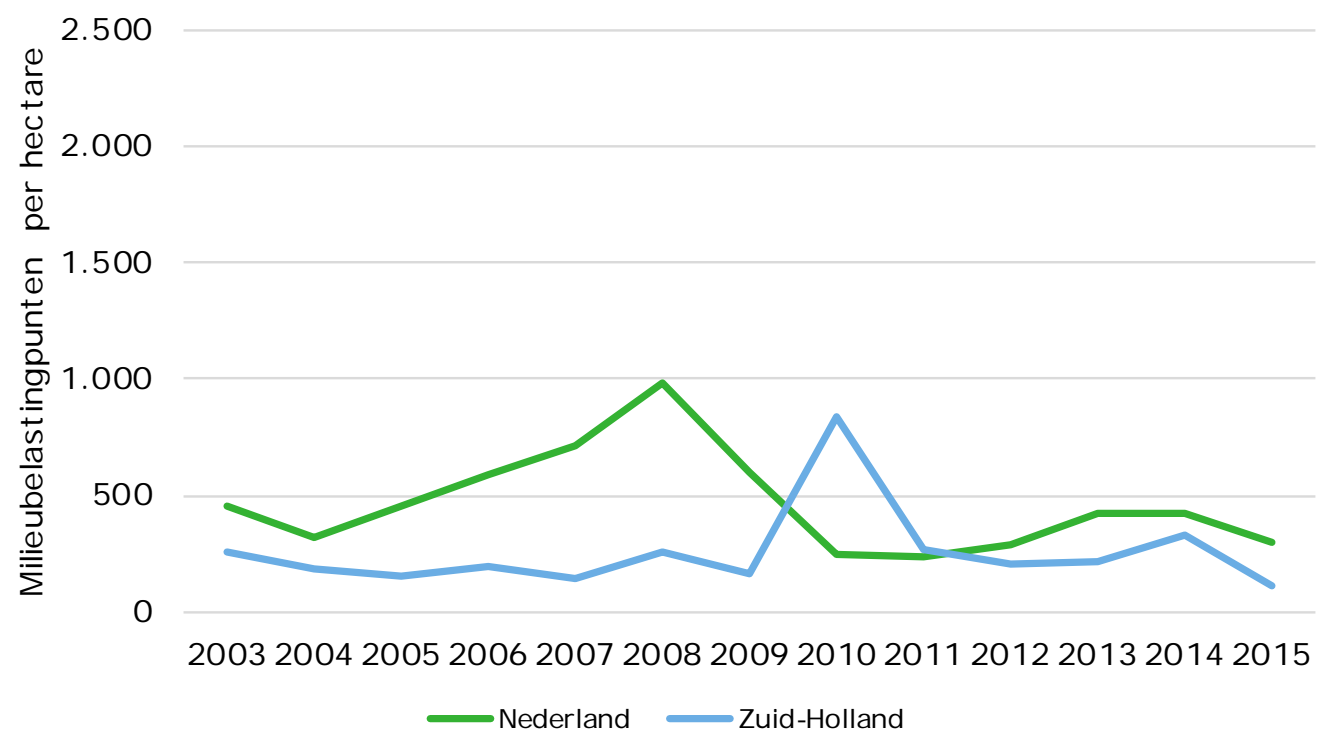

Figuur 4.22 Milieubelastingspunten per hectare op melkveebedrijven Bron: Bedrijveninformatienet, Wageningen Economic Research.

\subsection{Fijnstof}

\section{Definitie van gehanteerde indicatoren}

Fijnstof betreft de emissie van zwevende stofdeeltjes naar de lucht. De bijdrage van de akkerbouw en de melkveehouderij aan de totale fijnstof emissie in Zuid-Holland is beperkt. Veel onderzoek is gedaan naar het effect van de emissie van fijnstof op de gezondheid van de veehouderij (Maassen et al., 2016). Er is aangetoond dat de emissie van fijnstof aandoeningen aan de luchtwegen kan veroorzaken. De emissie van fijnstof wordt vaak uitgedrukt in PM10. De term PM staat voor ‘Particulate Matter'. Het getal achter de PM-aanduiding geeft de doorsnee van de deeltjes in micrometer. PM10 betekent bijvoorbeeld stofdeeltjes met een doorsnee tot 10 micrometer $(\mu \mathrm{m})$.

\section{Rundveehouderij}

Over de periode 2010-2014 is de landbouw verantwoordelijk voor 2,6\% van de totale fijnstof emissie. Circa 15\% daarvan is afkomstig uit de rundveehouderij (figuur 4.23). Op de Emissieregistratie wordt de cumulatieve fijnstofemissie uit de rundveehouderij gerapporteerd naar regio. Fijnstof kent verschillende bronnen, zoals verkeer, industrie en landbouw. Landelijk gezien wordt ongeveer een kwart van de fijnstofemissie veroorzaakt door de landbouw. Tweederde deel daarvan komt uit de pluimveehouderij. 


\subsection{0}

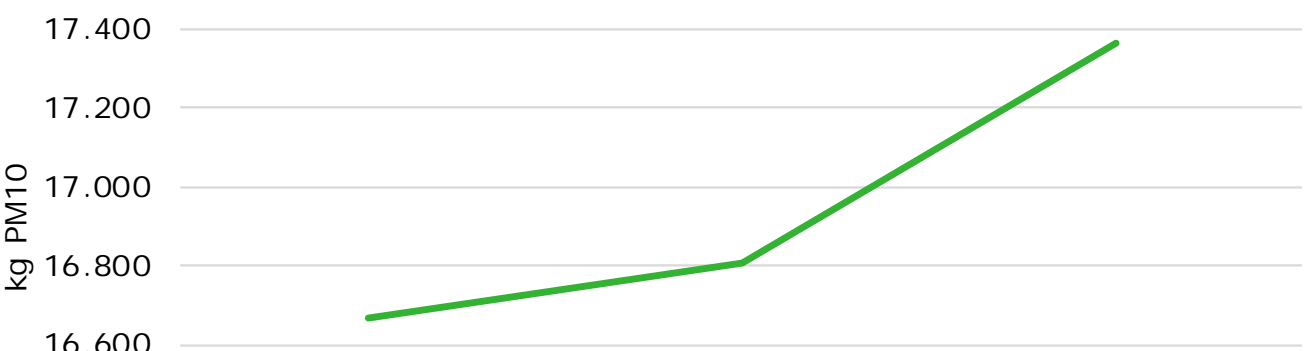

16.600

16.400

16.200

Figuur 4.23 Fijnstof emissie (PM10) uit de rundveehouderij in Zuid-Holland Bron: Emissieregistratie. $\mathrm{nl}$, bewerking Wageningen Economic Research.

\subsection{Water}

\section{Akkerbouw}

Het leidingwatergebruik op akkerbouwbedrijven is beperkt. In Zuid-Holland werd er in 2015 ongeveer 2,5 $\mathrm{m}^{3}$ per hectare gebruikt. De akkerbouwbedrijven in Zuid-Holland gebruiken meestal iets meer dan gemiddeld in Nederland (figuur 4.24). Voor beregening wordt beduidend meer water gebruikt, ruim $300 \mathrm{~m}^{3}$ per hectare in 2015. In jaren met weinig neerslag zoals in 2010, kan dit oplopen tot meer dan $600 \mathrm{~m}^{3}$ per hectare (figuur 4.25). Voor beregening wordt vrijwel uitsluitend grondwater en oppervlaktewater gebruikt.

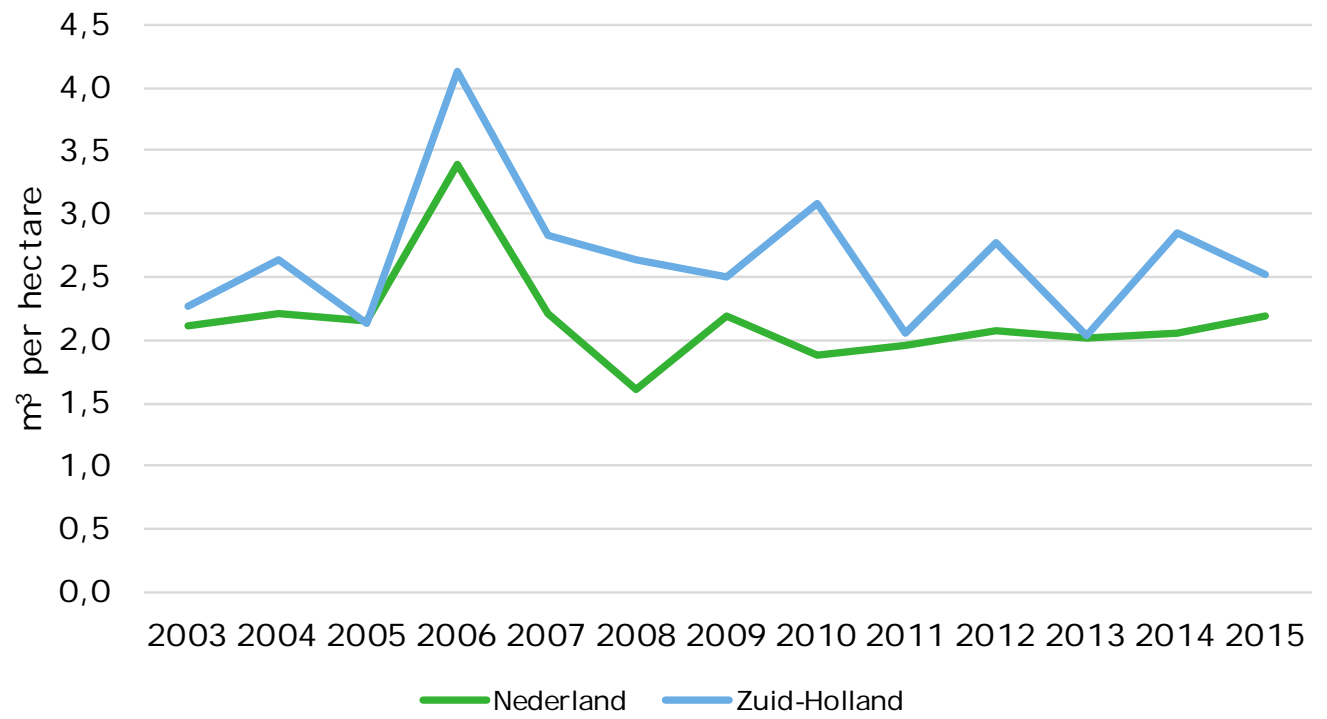

Figuur 4.24 Leidingwatergebruik per ha op akkerbouwbedrijven Bron: Bedrijveninformatienet, Wageningen Economic Research. 


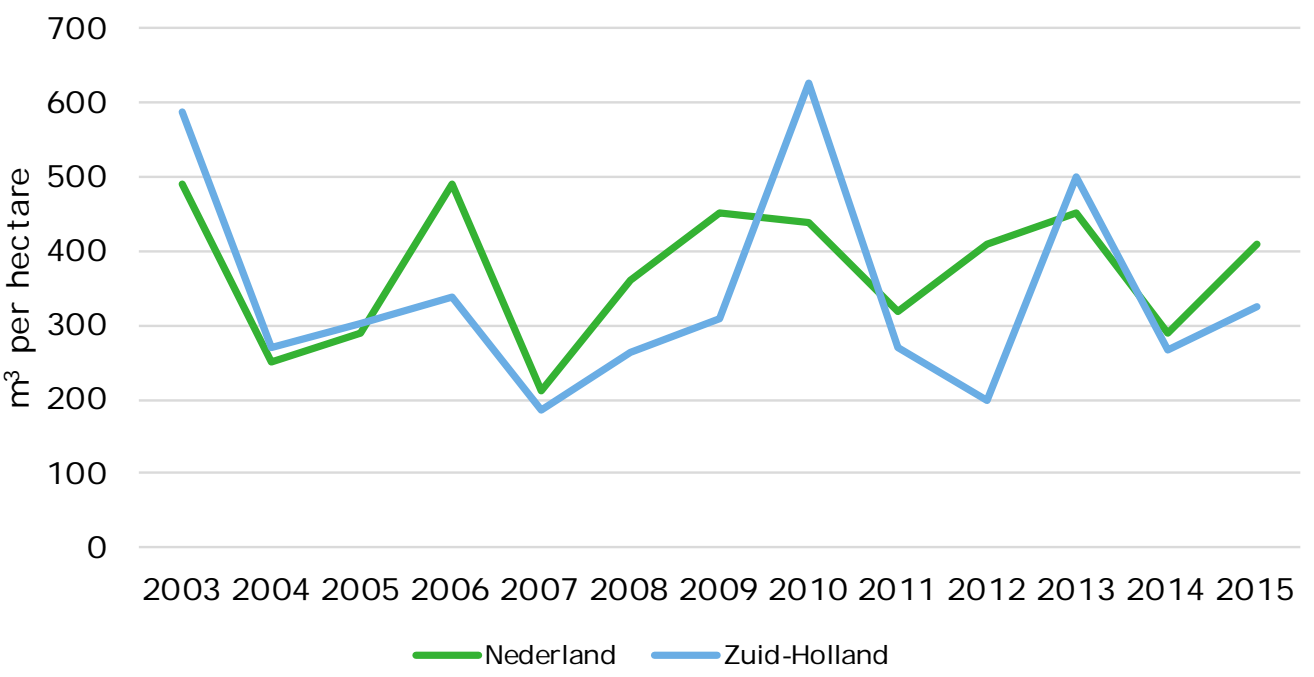

Figuur 4.25 Watergebruik voor beregening per beregende ha op akkerbouwbedrijven Bron: Bedrijveninformatienet, Wageningen Economic Research.

\section{Melkveehouderij}

In Zuid-Holland blijft de melkproductie per koe achter bij het landelijke gemiddelde. Dit betekent dat er naar verhouding meer koeien nodig zijn om dezelfde hoeveelheid melk te produceren. Dit heeft tot gevolg dat naar verhouding meer leidingwater nodig is voor dezelfde melkproductie (figuur 4.26). Voor het gemiddelde melkveebedrijf in Nederland is juist een lichte afname per ton melk waarneembaar. Het leidingwater wordt niet alleen als drinkwater, maar ook voor de reiniging van de melkapparatuur en melkstal gebruikt. Met name robotmelkstallen verbruiken meer water per kg melk. Echter, tussen de verschillende typen zijn er grote verschillen.

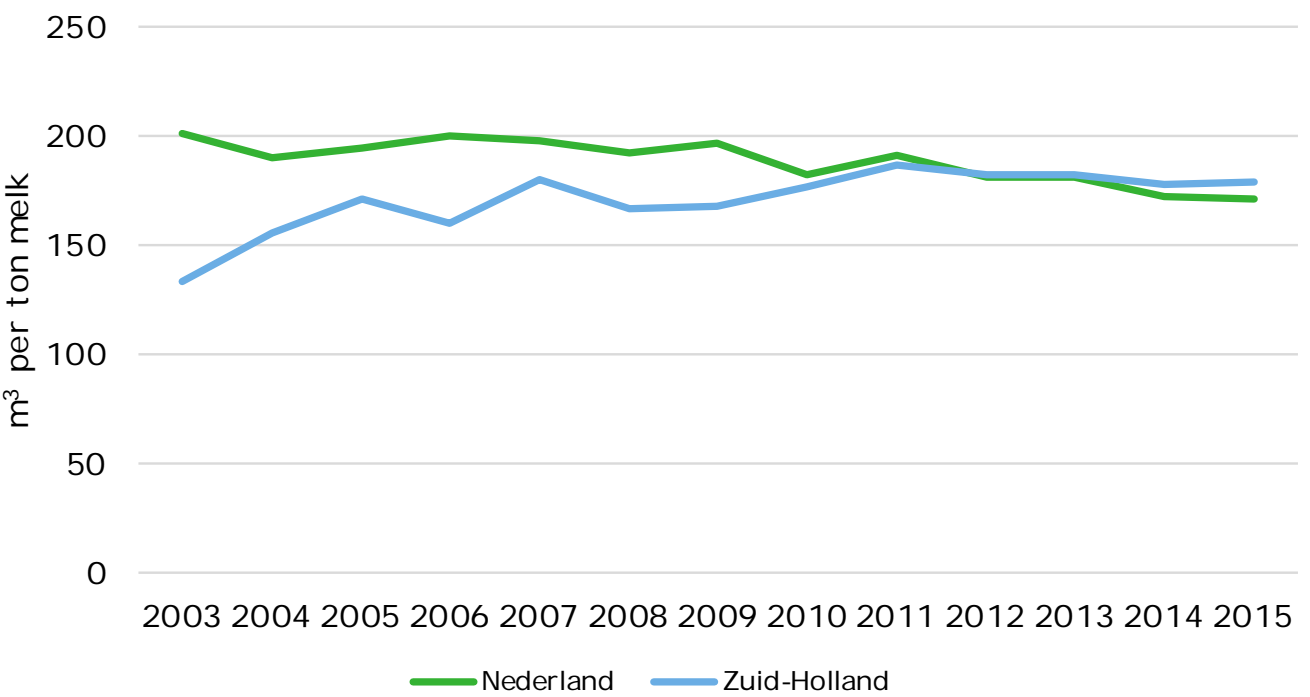

Figuur 4.26 Leidingwatergebruik per ton melk op melkveebedrijven Bron: Bedrijveninformatienet, Wageningen Economic Research.

Het waterverbruik voor beregening ligt op melkveebedrijven in Zuid-Holland op een lager niveau (figuur 4.27) dan landelijk. Dit is verklaarbaar omdat in de Hollandse veen/weide gebieden minder beregening nodig is vanwege het hoge waterpeil. Dit om het inklinken van het veen tegen te gaan. 


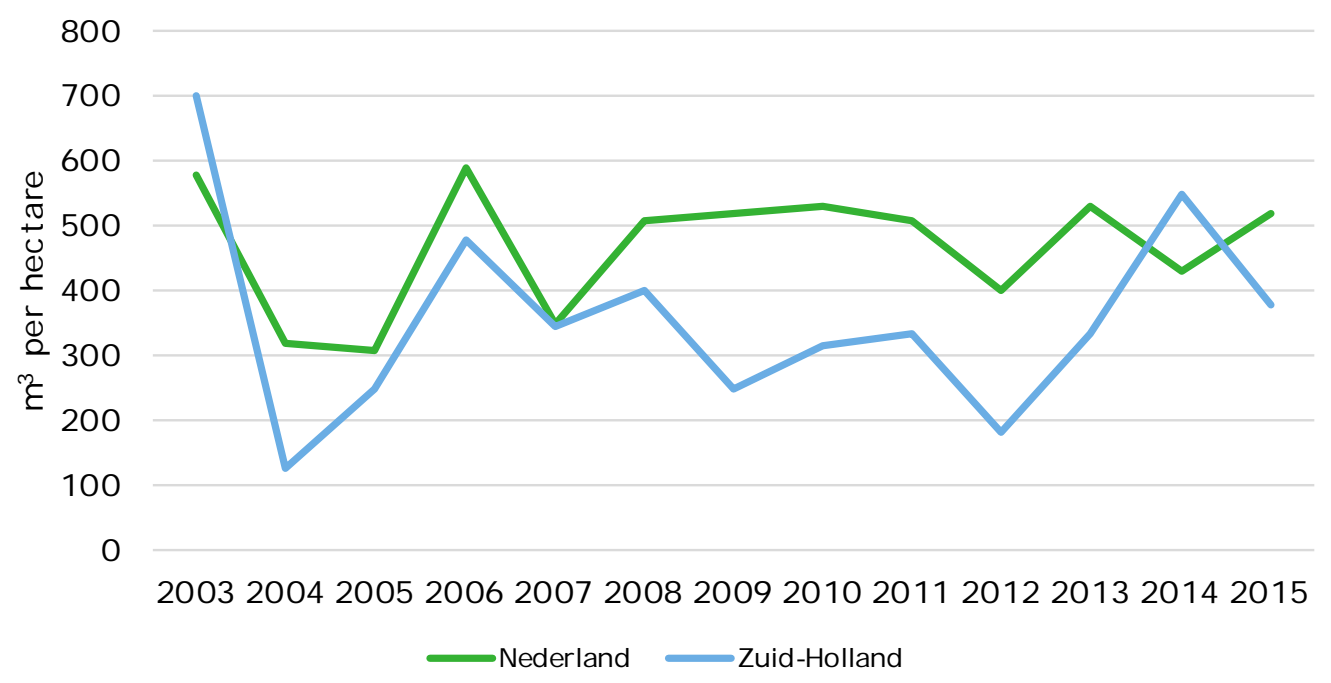

Figuur 4.27 Watergebruik voor beregening per beregende ha op melkveebedrijven Bron: Bedrijveninformatienet, Wageningen Economic Research.

\subsection{Biodiversiteit}

\section{Definitie van gehanteerde indicatoren}

Het thema biodiversiteit maakt onderdeel uit van de voortgangsrapportage Groen van de Provincie Zuid-Holland dat in april 2017 is verschenen. Het thema biodiversiteit wordt daarin opgenomen en daarbij zal geen onderscheid gemaakt worden naar de grondgebonden sectoren akkerbouw en melkveehouderij.

Voor akkerbouw kan een link worden gelegd met het door de provincie gestelde doel om de biodiversiteit te versterken, en wel door gebruik te maken van de indicator aandeel duurzaam teeltareaal van akkerbouwgewassen. Het gaat hierbij om het areaal dat voldoet aan het certificatieschema van Milieukeur met criteria voor gewasbeschermingsmiddelen en meststoffen, energie- en watergebruik, broeikasgasemissie en effect op de biodiversiteit en het areaal biologische akkerbouwgewassen.

Voor melkveehouderij is er geen indicator voor biodiversiteit. De Duurzame zuivelketen heeft zich als doel gesteld om geen nettoverlies aan biodiversiteit te hebben en werkt in 2017 aan een verbeterde monitoringssystematiek om dit in beeld te brengen.

\section{Box 4.4 Aandeel duurzaam teeltareaal maakt onderdeel uit van de samengestelde effectindicator}

Het versterken van de biodiversiteit is een belangrijk doel van de provincie Zuid-Holland. Deze indicator is opgenomen in de samengestelde effectindicator voor de akkerbouw (zie hoofdstuk 6).

\section{Duurzaam teeltareaal}

Het aandeel duurzaam teeltareaal in de provincie Zuid-Holland bedraagt 1,7\% van het areaal akkerbouwgewassen. Dit areaal bestaat volledig uit biologische gewassen (zie paragraaf 2.5). Er is geen areaal akkerbouwgewassen dat door Milieukeur is gecertificeerd. Er zijn wel andere bedekte en opengrondsteelten (fruit- en boomteelt) Milieukeur gecertificeerd in de provincie Zuid-Holland. 


\title{
5 Profit
}

\subsection{Macro-economie}

\begin{abstract}
Akkerbouw
Het totale akkerbouwcluster (inclusief de verwerking van buitenlandse grondstoffen) was in ZuidHolland in 2013 goed voor ruim 2,3 miljard euro toegevoegde waarde en een werkgelegenheid van bijna 24.000 arbeidsjaren. Het akkerbouwcluster is, wat betreft toegevoegde waarde, in Zuid-Holland na het glastuinbouwcluster de tweede agrocluster in belangrijkheid. Ongeveer $18 \%$ van de toegevoegde waarde hangt samen met de productie en verwerking van binnenlandse akkerbouwproducten. Door de aanwezigheid van de Rotterdamse haven worden er in Zuid-Holland relatief veel buitenlandse agrarische grondstoffen verwerkt in bijvoorbeeld de oliën- en vettenindustrie, de meelindustrie en de veevoederindustrie (Vogelzang et al., 2016).
\end{abstract}

\section{Melkveehouderij}

Voor de melkveehouderij specifiek is geen macro-economische waarde bekend, wel voor de grondgebonden veehouderij in Zuid-Holland, welke voor het grootste gedeelte uit de melkveehouderij bestaat. Het grondgebonden veehouderijcluster realiseerde in Zuid-Holland in 2013 bijna 900 miljoen euro toegevoegde waarde en een werkgelegenheid van ruim 12.000 arbeidsjaren. Op de primaire melkveebedrijven zelf wordt $12 \%$ van de toegevoegde waarde en $22 \%$ van de werkgelegenheid van dit cluster gerealiseerd (Vogelzang et al., 2016).

\subsection{Economisch resultaat}

\section{Definitie van gehanteerde indicatoren}

Een belangrijke indicator om te beoordelen of de gezinsuitgaven gefinancierd kunnen worden, is het inkomen uit bedrijf. Om er rekening mee te houden dat het inkomen uit bedrijf soms gedeeld moet worden met verschillende ondernemers (arbeidsjaareenheden (aje's)), wordt de indicator inkomen uit bedrijf uitgedrukt per onbetaalde aje. Inkomen uit bedrijf per onbetaalde arbeidsjaareenheid (aje) is in (inter)nationaal verband de meest gebruikte indicator waardoor benchmarking mogelijk is. Een belangrijke vorm van innovatie die bijdraagt aan de verduurzaming van de sector met kansen voor ontplooiing van nieuwe verdienmodellen zijn korte ketens. In Vogelzang et al. (2016) is een uiteenzetting gemaakt van de betekenis van korte ketens. Er zijn in politiek en maatschappij een aantal ontwikkelingen gaande die leiden tot vragen om ketenverkorting en ketenomkering. Voedingsbedrijven kopen hun grondstoffen steeds minder in op anonieme markten en steeds meer via bekende toeleveranciers. Deze trend heeft onder andere te maken met gezondheidsvoordelen van versketens, maar ook het verminderen van de transportafstand (food miles). Daarnaast spelen vragen over arbeids- en milieuomstandigheden of een eerlijke verdeling van schaarse grondstoffen een rol. In Vogelzang et al. (2016) wordt echter ook gesteld dat de duurzaamheidseffecten van korte ketens nog lastig te kwantificeren zijn. In de provincie Zuid-Holland zijn tal van initiatieven waarbij de keten verkort wordt door aan huisverkoop te doen. Dit kengetal wordt met enige regelmaat uitgevraagd in de Landbouwtelling. 
Een belangrijke indicator om te beoordelen of de gezinsuitgaven gefinancierd kunnen worden, is het inkomen uit bedrijf. Een belangrijke vorm van innovatie die bijdraagt aan de verduurzaming van de sector met kansen voor ontplooiing van nieuwe verdienmodellen zijn korte ketens. In de provincie Zuid-Holland zijn tal van initiatieven waarbij de keten verkort wordt door aan huisverkoop te doen. Dit kengetal wordt met enige regelmaat uitgevraagd in de Landbouwtelling. Deze indicatoren zijn opgenomen in de samengestelde effectindicator voor de akkerbouw en de melkveehouderij (zie hoofdstuk 6).

\section{Akkerbouw}

Vooral door schommelingen in de productie en het prijsniveau van de akkerbouwgewassen, schommelt ook het inkomen uit bedrijf per onbetaalde aje op akkerbouwbedrijven in Zuid-Holland en in Nederland (figuur 5.1). Het verloop van het inkomen per onbetaalde aje in Zuid-Holland loopt behoorlijk parallel met de ontwikkeling van de totale akkerbouwsector. De jaren 2010 en 2012 waren uitzonderlijk goede jaren met inkomens van gemiddeld 100.000 euro per onbetaalde aje. In 2004 en 2014 werd er gemiddeld niets verdiend.

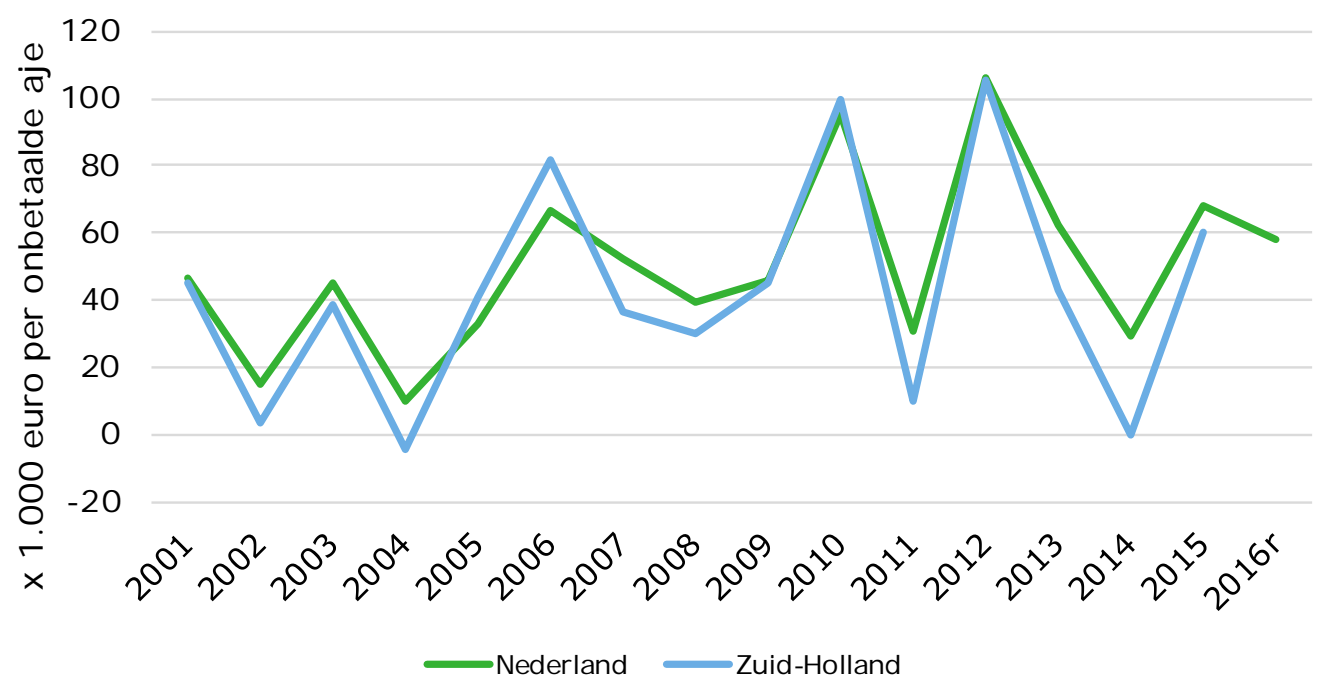

Figuur 5.1 Inkomen per onbetaalde arbeidsjaareenheid op akkerbouwbedrijven Bron: Bedrijveninformatienet, Wageningen Economic Research.

De spreiding in de inkomensresultaten tussen bedrijven is aanzienlijk en lijkt ook steeds verder toe te nemen (figuur 5.2). In de goede jaren 2010 en 2012 behaalden ongeveer $20 \%$ van de bedrijven een inkomen van nul of minder, terwijl de $20 \%$ beste bedrijven meer dan 200.000 euro verdienden. Verschillen worden veroorzaakt door verschillen in productie, kwaliteit van de gewassen en het tijdstip en wijze van de afzet. Bijvoorbeeld het afzetten van aardappelen op basis van contracten geeft zekerheid en redelijk stabiele prijzen over de jaren. Het nadeel is dat als de aardappelprijzen in een jaar hoog zijn hier niet van geprofiteerd kan worden. 


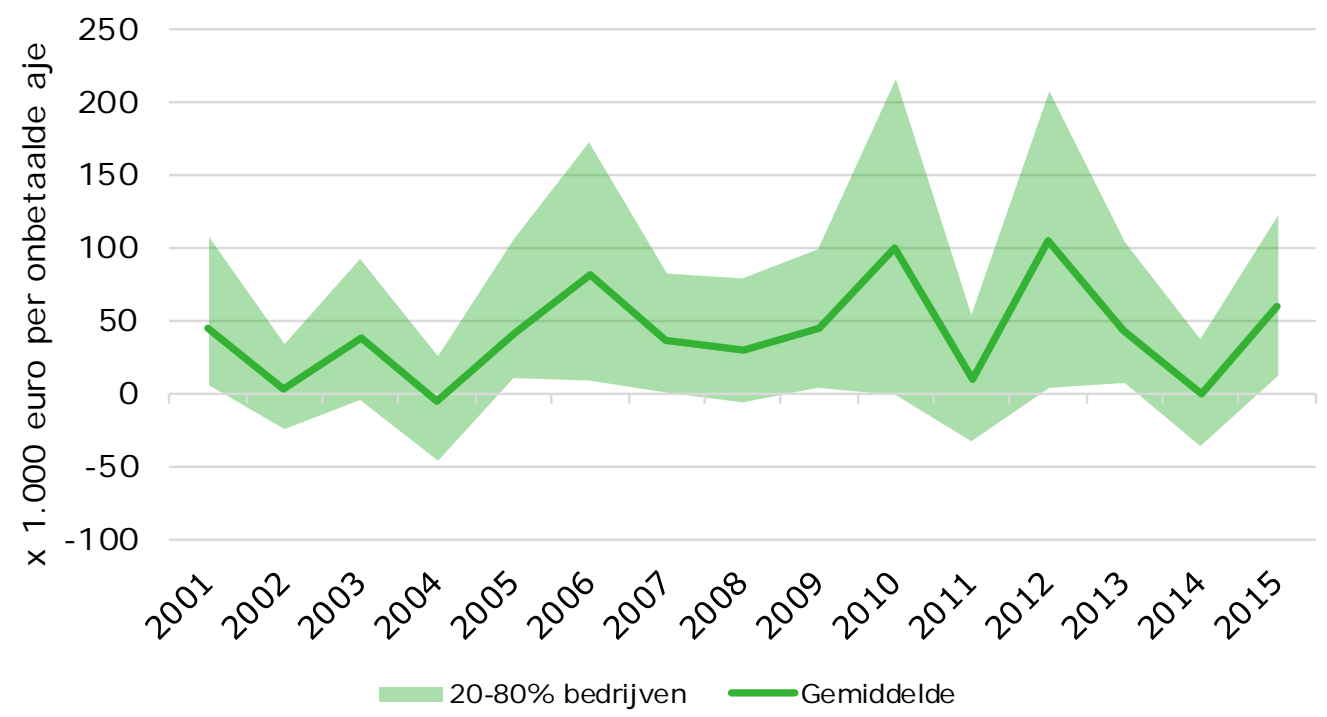

Figuur 5.2 Spreiding in inkomen per onbetaalde arbeidsjaareenheid op akkerbouwbedrijven in ZuidHolland

Bron: Bedrijveninformatienet, Wageningen Economic Research.

In de provincie Zuid-Holland is het aandeel akkerbouwbedrijven dat boerderijverkoop toepast relatief hoog. In 2016 paste ruim 7,2\% van de bedrijven een vorm van huisverkoop toe. Dat ligt ruim boven het Nederlandse gemiddelde (figuur 5.3).

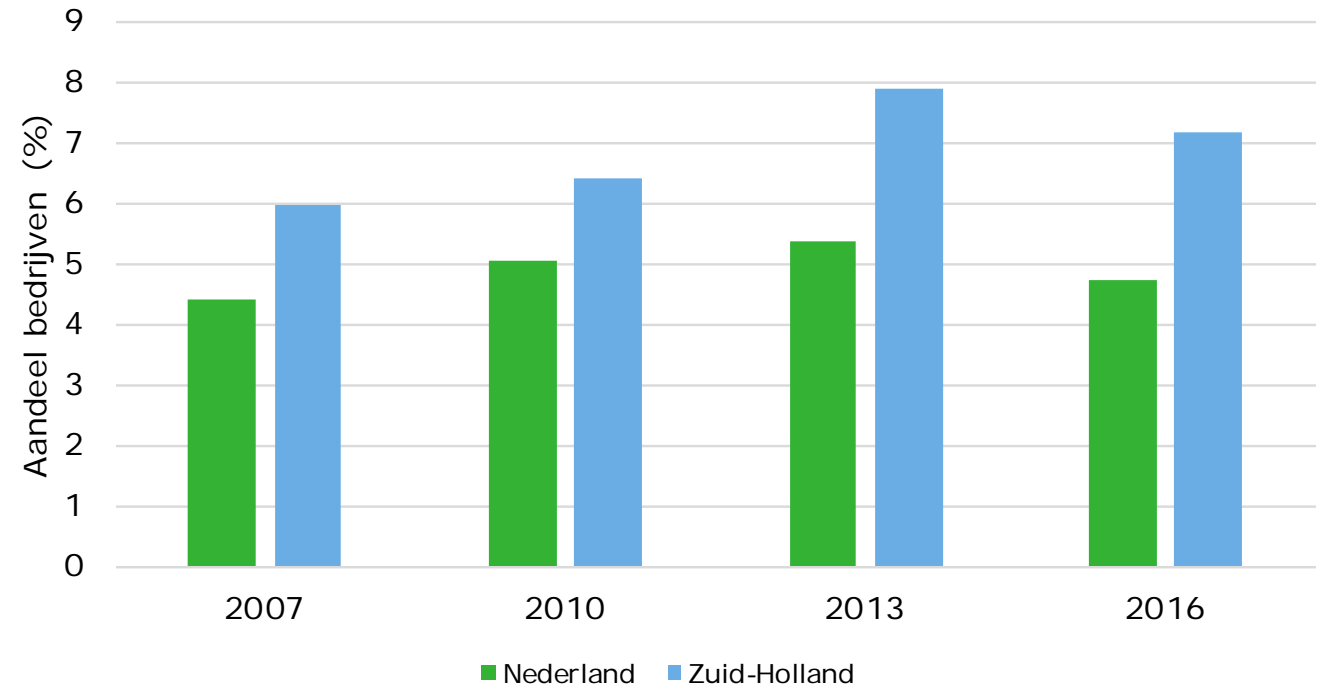

Figuur 5.3 Aandeel akkerbouwbedrijven dat huisverkoop toepast Bron: CBS, bewerking Wageningen Economic Research.

\section{Melkveehouderij}

Het gemiddelde inkomen uit bedrijf per onbetaalde arbeidsjaareenheid op melkveebedrijven in Nederland en Zuid-Holland ontloopt elkaar niet veel (figuur 5.4). De laatste jaren wijkt dit inkomen in Zuid-Holland in positieve zin af met die van Nederland. Met name de kosten zijn lager op bedrijven in Zuid-Holland. Enerzijds gaat het hier om lagere rentekosten, doordat melkveebedrijven in ZuidHolland minder zwaar gefinancierd zijn dan het gemiddelde bedrijf in Nederland. Anderzijds speelt hier het bouwplan mogelijk ook een rol. Bedrijven in Zuid-Holland zijn extensiever dan het gemiddelde melkveebedrijf in Nederland en voeren minder krachtvoer aan. De voerkosten vallen daardoor ook iets lager uit dan. 
Nadat de Europese prijsondersteuning grotendeels wegviel (vanaf 2007) fluctueren de inkomens in de melkveehouderij meer dan daarvoor. Lage inkomens in 2009 en 2016 en hoge in 2011, 2013 en 2014. Ook de mate van spreiding hangt hiermee samen (figuur 5.5). Daarnaast is er het effect van sterk fluctuerende marktprijzen. In goede jaren met een hoge melkprijs zijn er duidelijk pieken waarneembaar in positieve zin. Door de schaalvergroting gaan hoge prijzen gepaard met hoge inkomens. Door het wegvallen van de afschrijving op het melkquotum (door het vervallen van de melkquotering per 1 april 2015) zijn de inkomens nog relatief op peil gebleven in 2015 en 2016, maar de melkprijs was historisch gezien laag en vergelijkbaar met 2009.

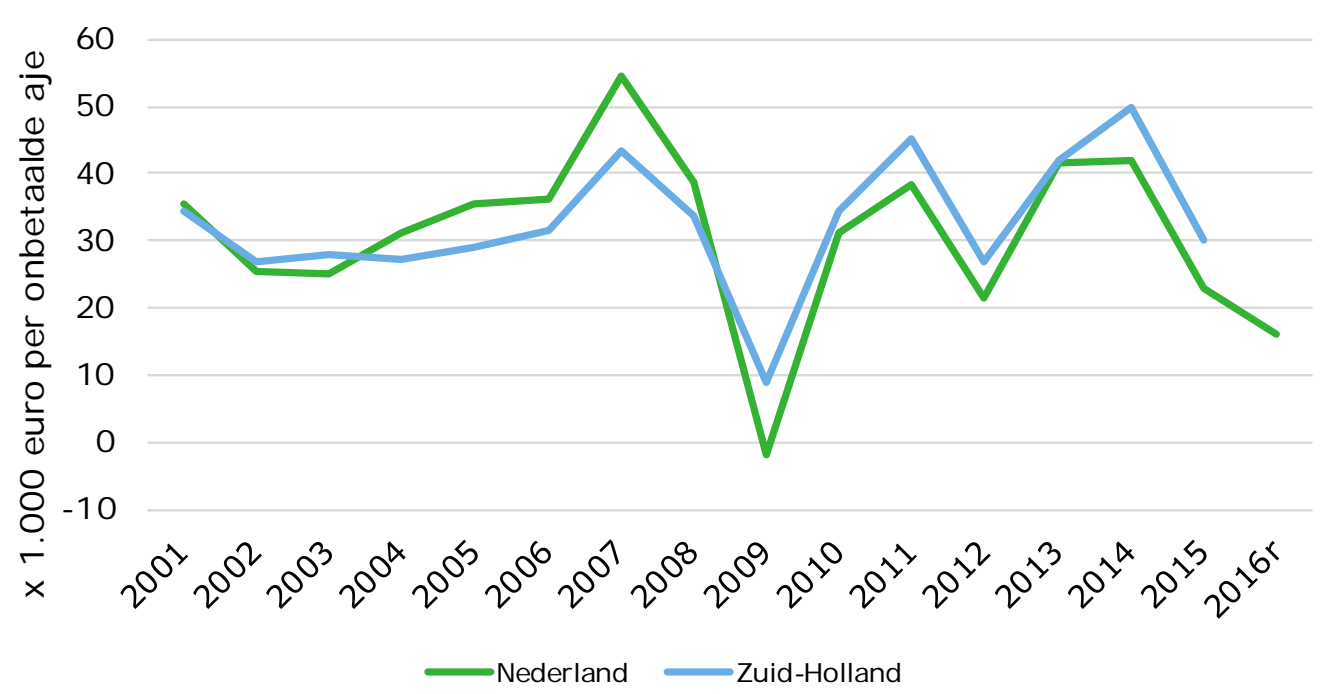

Figuur 5.4 Inkomen per onbetaalde arbeidsjaareenheid op melkveebedrijven Bron: Bedrijveninformatienet, Wageningen Economic Research.

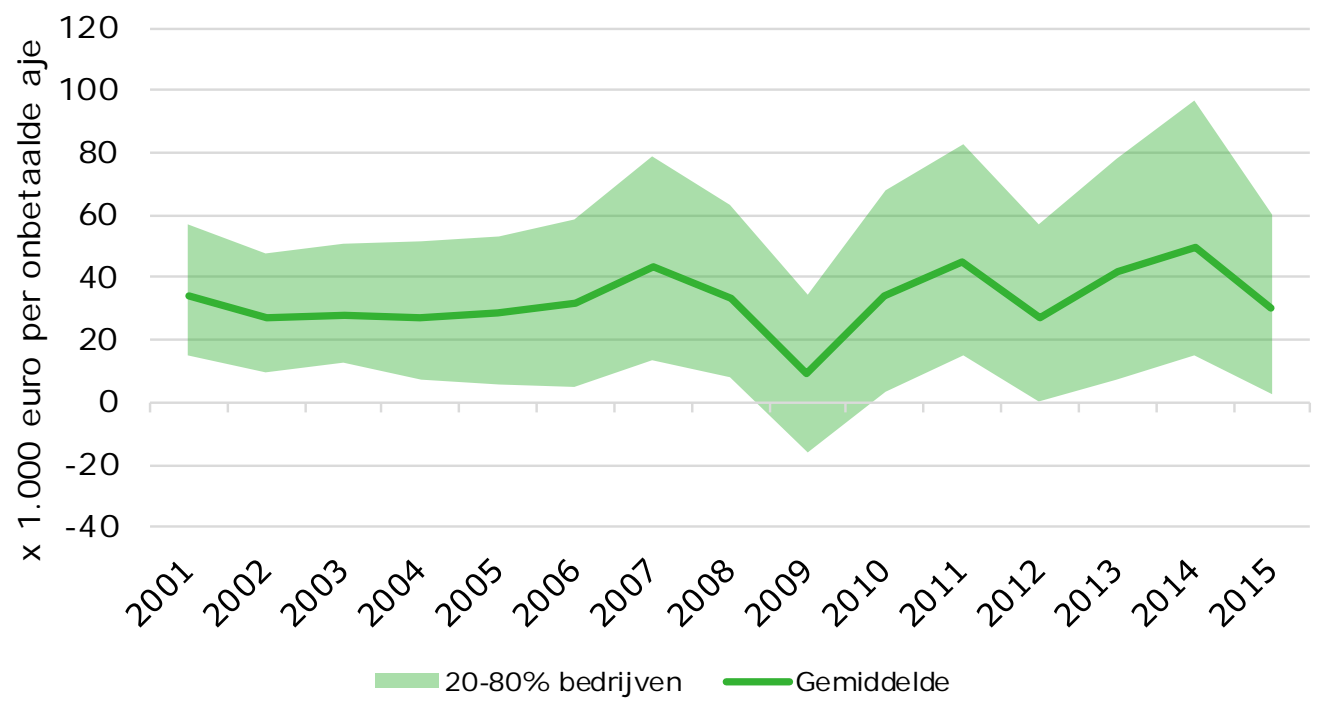

Figuur 5.5 Spreiding in inkomen per onbetaalde arbeidsjaareenheid op melkveebedrijven in ZuidHolland

Bron: Bedrijveninformatienet, Wageningen Economic Research

Het aandeel melkveebedrijven dat huisverkoop toepast, is net als bij de akkerbouwbedrijven hoger in de provincie Zuid-Holland in vergelijk met het Nederlandse gemiddelde (figuur 5.6). In 2016 paste $6,5 \%$ van de melkveebedrijven een vorm van huisverkoop toe. Dat is een afname van bijna 2,5 procentpunten ten opzichte van het jaar 2007. Sinds 2007 neemt het aandeel bedrijven dat huisverkoop toepast terug in Zuid-Holland, terwijl het Nederlands gemiddelde op stabiel rond de 2,5\% zit. Mogelijke verklaring is de toenemende schaalvergroting en specialisatie. 


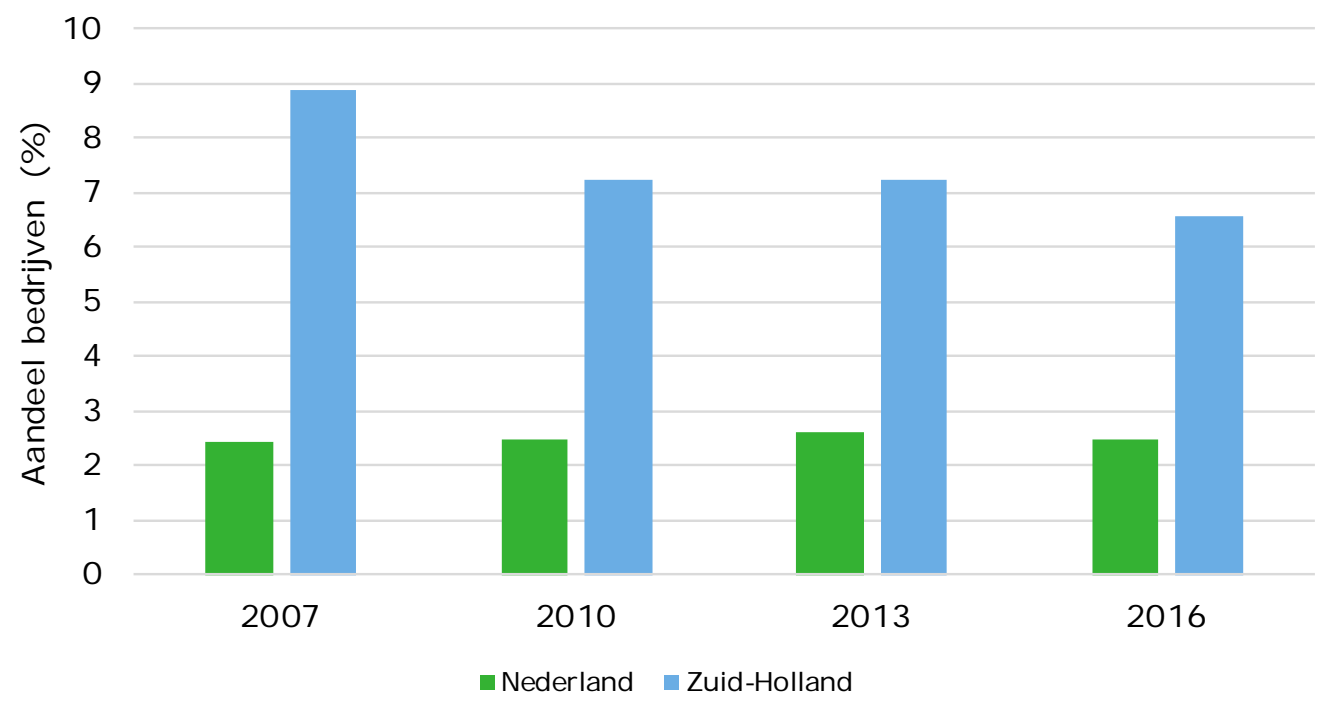

Figuur 5.6 Aandeel melkveebedrijven dat huisverkoop toepast Bron: CBS, bewerking Wageningen Economic Research.

\subsection{Balans en financiering}

\section{Definitie van gehanteerde indicatoren}

Behalve in de inkomenspositie is het van belang inzicht te geven in de vermogenspositie. Een veel gebruikte indicator voor het weergeven van de mate waarin een bedrijf met vreemd vermogen is gefinancierd, is de solvabiliteit. Met de solvabiliteit wordt inzicht gegeven in de schuldenpositie van het primaire bedrijf. Als de solvabiliteit echter te laag wordt, kan een bedrijf wel in financiële moeilijkheden komen en kan het moeilijk zijn om leningen te verkrijgen voor het doen van nieuwe investeringen. Een kengetal om innovatie van bedrijven op basis van de balanswaarde inzichtelijk te maken is de moderniteit van bedrijven. De moderniteit geeft de verhouding weer tussen de nieuw- en boekwaarde van de duurzame productiemiddelen. Hoe ouder de duurzame productiemiddelen zijn, hoe langer er is afgeschreven, hoe lager de moderniteit. Een voorbeeld: een machine wordt gekocht voor 100.000 euro en er wordt gemiddeld met 10.000 euro per jaar afgeschreven. De boekwaarde bedraagt dan na vier jaren 60.000 euro, de moderniteit van deze machine is dan $60 \%$. Halverwege de bedrijfseconomische levensduur is twee derde afgeschreven. In het begin daalt de moderniteit sterker dan aan het eind. Investeringen leiden tot een toename van de moderniteit. De moderniteit wordt alleen bepaald voor de categorieën gebouwen $\&$ glasopstanden en machines, werktuigen $\&$ installaties.

\section{Akkerbouw}

De solvabiliteit (aandeel van het eigen vermogen in het totale vermogen) bedroeg in 2016 bijna $80 \%$ op akkerbouwbedrijven in Zuid-Holland (figuur 5.7). Over het algemeen hebben de bedrijven in de grondgebonden sectoren zoals de akkerbouw een goede solvabiliteit. Dit is het gevolg van de waardestijging van de grond. De waarde van grond maakt een belangrijk deel uit van de totale waarde van het akkerbouwbedrijf. De meeste jaren ligt de solvabiliteit in Zuid-Holland iets hoger dan gemiddeld in Nederland. Vanuit het oogpunt van risicobeheer is het belangrijk dat bedrijven over een voldoende grote financiële buffer beschikken om inkomensfluctuaties op te vangen. Een lage solvabiliteit maakt bedrijven kwetsbaar voor dergelijke schommelingen. 


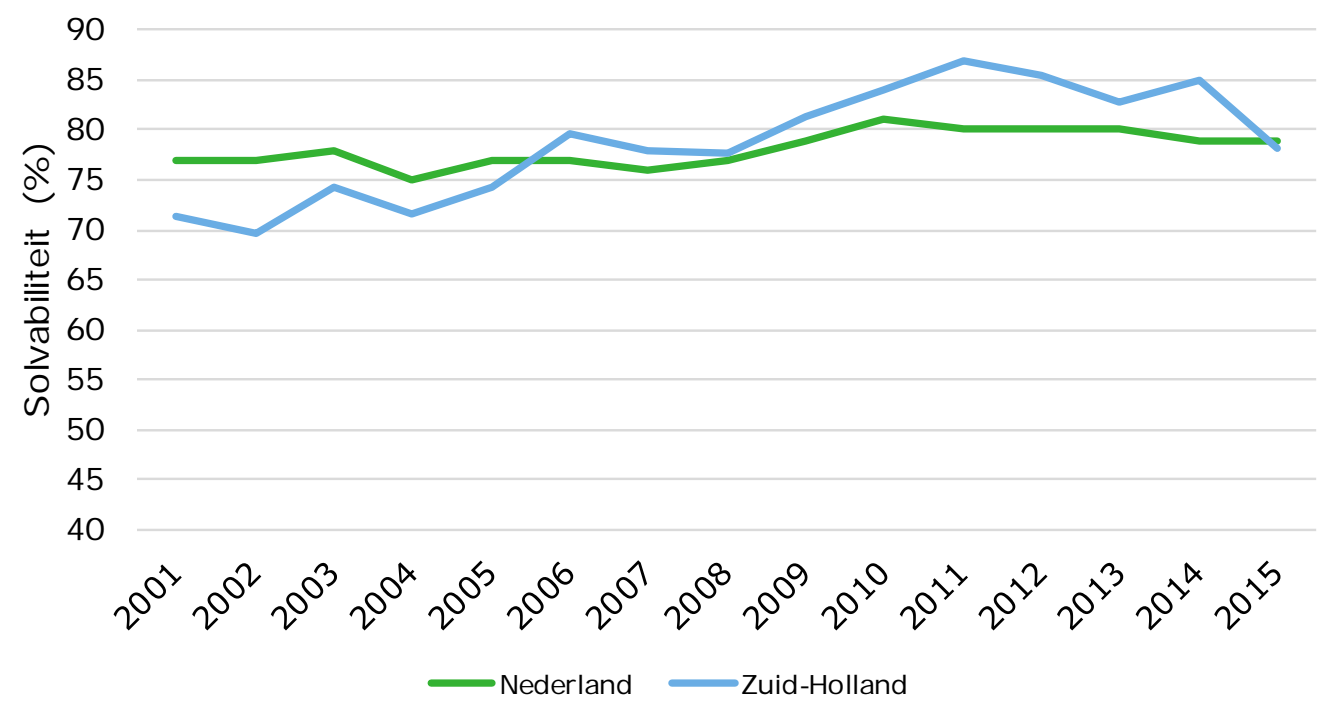

Figuur 5.7 Solvabiliteit op akkerbouwbedrijven

Bron: Bedrijveninformatienet, Wageningen Economic Research.

De moderniteit (boekwaarde ten opzichte van de nieuwwaarde) van de bedrijfsgebouwen is toegenomen op akkerbouwbedrijven in Zuid-Holland (figuur 5.8). Mede dankzij de financieel goede jaren 2010 en 2012 kwamen financiële middelen beschikbaar voor investeringen. Vooral in gebouwen, zoals aardappelbewaarplaatsen is vernieuwd. Investeringen in machines en werktuigen waren voldoende om de moderniteit op een stabiel niveau te houden. Naast investeringen in gebouwen en machines, is er ook geïnvesteerd in grond. Deze investeringen komen niet tot uitdrukking in het kengetal nieuwwaarde. Investeringen komen vaak in pieken. Een of twee jaar na een jaar met goede resultaten, wordt er geïnvesteerd.

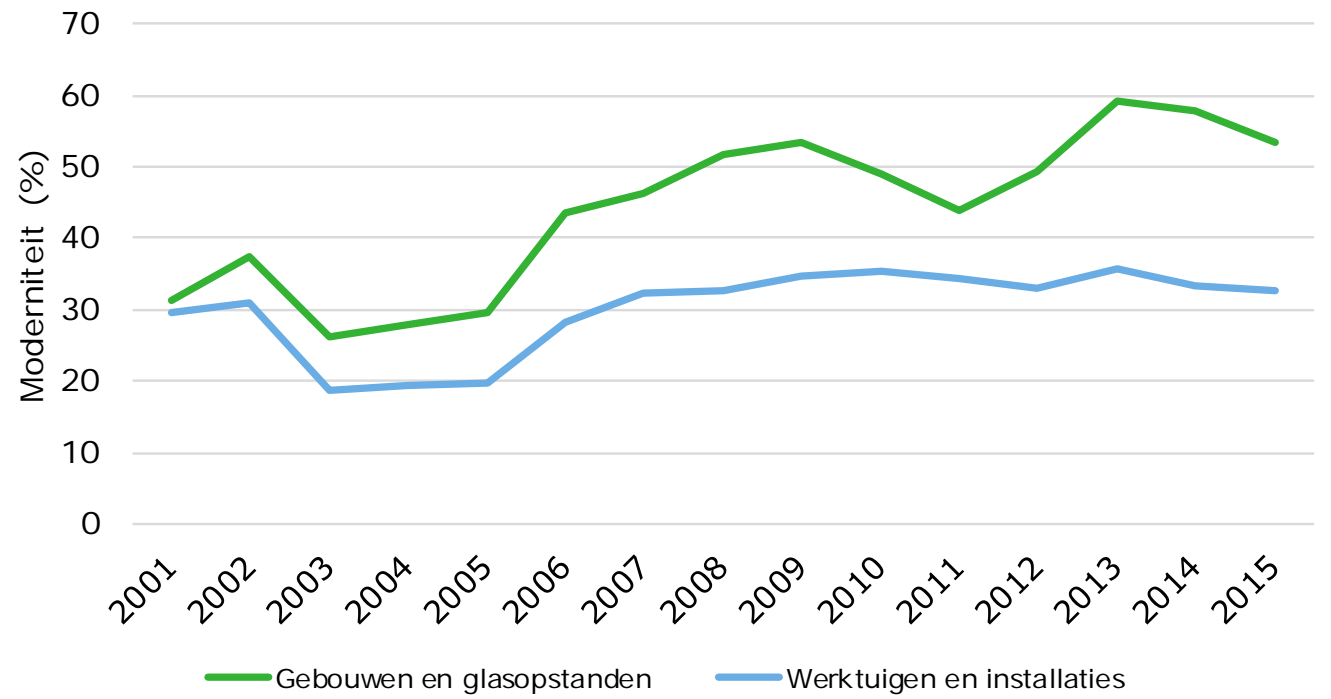

Figuur 5.8 Moderniteit op akkerbouwbedrijven in Zuid-Holland Bron: Bedrijveninformatienet, Wageningen Economic Research.

\section{Melkveehouderij}

De solvabiliteit ontwikkelt zich in Nederland in negatieve zin, terwijl in Zuid-Holland de solvabiliteit zich juist in positieve zin ontwikkelt (figuur 5.9). De totale balanswaarde is in Zuid-Holland groter door een groter aandeel grond in eigendom. Daarnaast is het aandeel vreemd vermogen kleiner. 


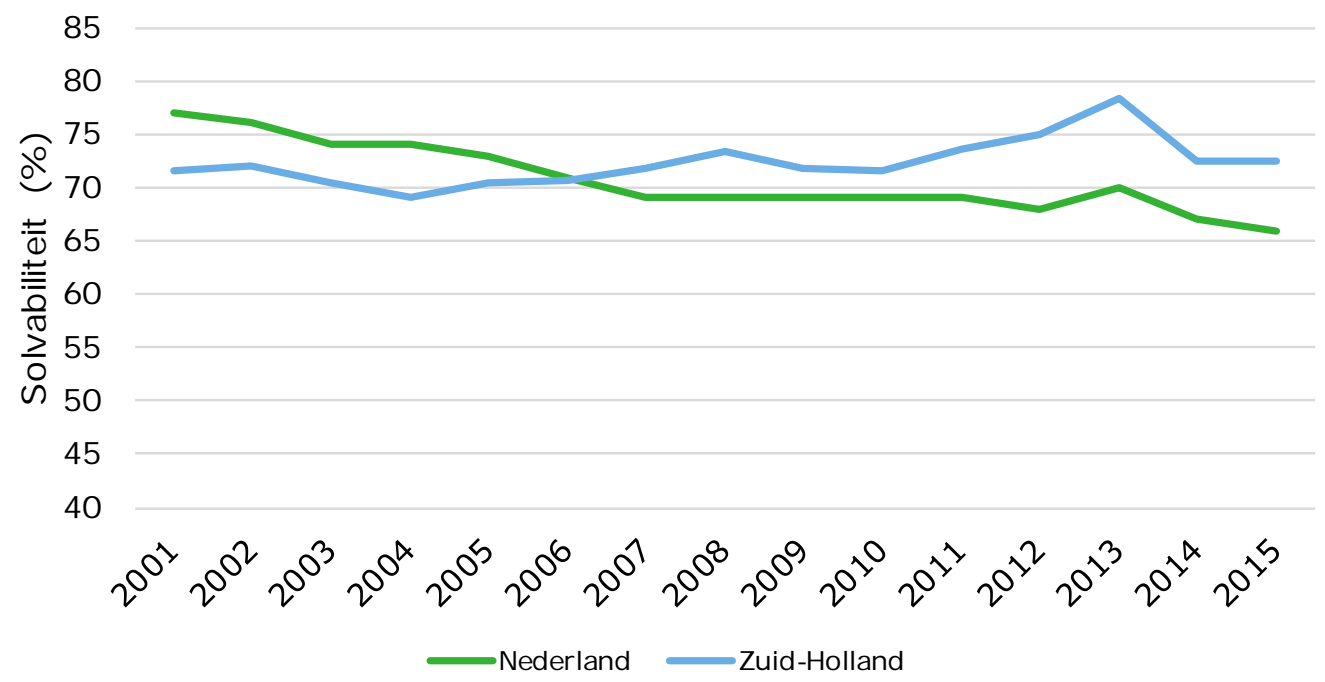

Figuur 5.9 Solvabiliteit op melkveebedrijven

Bron: Bedrijveninformatienet, Wageningen Economic Research.

De moderniteit van de gebouwen in Zuid-Holland is toegenomen van 30\% in 2004 naar 39\% in 2015 (figuur 5.10). Voor geheel Nederland lagen deze percentages hoger, maar bedraagt deze in 2015 $40 \%$. In Nederland is de ontwikkeling achtergebleven bij Zuid-Holland. Voor de werktuigen en installaties is de ontwikkeling per saldo minder positief.

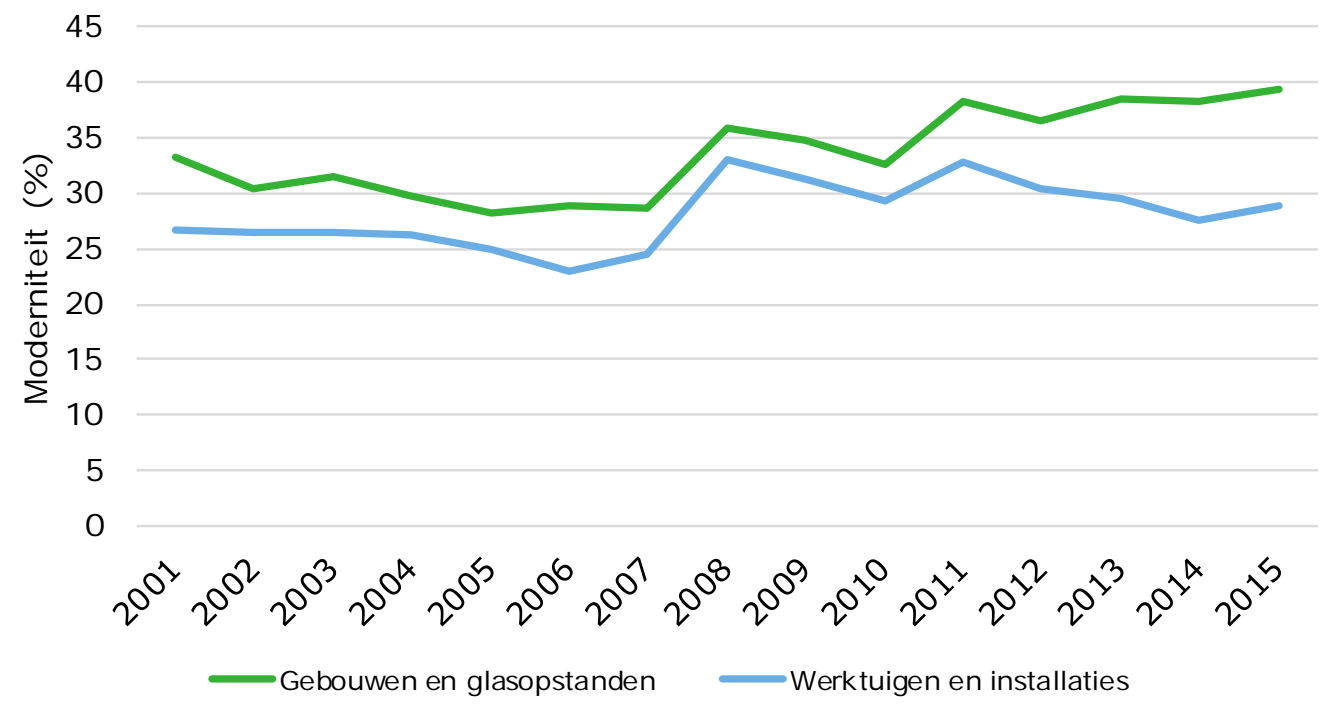

Figuur 5.10 Moderniteit op melkveebedrijven in Zuid-Holland Bron: Bedrijveninformatienet, Wageningen Economic Research. 


\section{Barometer duurzame landbouw: samengestelde effectindicator}

De Barometer gaat over de duurzaamheidsprestaties van de grondgebonden landbouw in Zuid-Holland en omvat een groot aantal indicatoren op people, planet en profit thema's. De Barometer beoogt de afzonderlijke thema's in samenhang en zo kwantitatief mogelijk te presenteren en vooruitgang van de volgende provinciale beleidsdoelen te meten: het verbeteren kwaliteit van de leefomgeving via verduurzaming door het sluiten van grondstofkringlopen, het versterken van regionale voedselketens en het versterken van de biodiversiteit bij normale agrarische bedrijfsvoering door nieuwe verdienmodellen. Daarnaast wil de provincie een sterke economisch cluster op lange termijn in stand houden.

Een selectie van indicatoren in deze nota (hoofdstuk 2 tot en met 5) is opgenomen in de Barometer duurzame landbouw. Voor het kiezen van de indicatoren voor de Barometer is gebruik gemaakt van de criteria in tabel 6.1 .

Tabel 6.1 Criteria voor het kiezen van de meest geschikte indicator

\begin{tabular}{ll}
\hline - Compleet & - Schaalbaar naar andere sectoren \\
\hline - Structureel beschikbaar & - Tijdig \\
\hline - Representatief & - Duidelijk \\
\hline - Kwantitatief & - Link micro (bedrijf) en macro (sector, land, regio) mogelijk \\
\hline - Breed gedragen & - Inzichtelijk qua spreiding \\
\hline - Eenvoudig uitvoerbaar & - Kosteneffectief \\
\hline - Robuust & - Betrouwbaar \\
\hline
\end{tabular}

\subsection{Barometer akkerbouw}

De Barometer duurzame akkerbouw Zuid-Holland laat zien dat de verschillen in duurzaamheidsprestaties van het jaar 2015 ten opzichte van de referentie, het meerjaarsgemiddelde (2010-2015), op de meeste indicatoren klein zijn (figuur 6.1). Het gemiddelde akkerbouwbedrijf in Zuid-Holland is beter gaan presteren op het gebied van fosfaatbenutting, milieubelastingspunten per ha, inkomen uit bedrijf en areaal duurzame teelt (groene vlakken in de figuur). Op het gebied van stikstofoverschot en energie- efficiëntie zijn bedrijven minder duurzaam (rode vlakken in de figuur) geworden.

Het fosfaatoverschot per hectare cultuurgrond nam in 2015 met $21 \%$ af ten opzichte van het meerjaarsgemiddelde doordat minder fosfaatkunstmeststoffen zijn gebruikt. De milieubelasting van gewasbescherming per hectare cultuurgrond nam af doordat er maatregelen zijn genomen om het verwaaien van middelen in het oppervlaktewater (drift) te verminderen, zoals andere spuitdoppen, luchtondersteuning en spuitvrije zones. Het inkomen per onbetaalde arbeidsjaareenheid in 2015 lag iets boven het meerjaarsgemiddelde, waarbij 2011 en 2014 hele matige jaren en 2010 en 2012 hele goede jaren waren. Daarnaast moet opgemerkt worden dat de inkomensverschillen tussen bedrijven groot zijn. Deze verschillen worden veroorzaakt door verschil in ondernemerschap, maar ook in bouwplannen, productie per hectare, kwaliteit van de gewassen en het tijdstip en de wijze van de afzet. Het stikstofbodemoverschot per hectare cultuurgrond nam in 2015 met $7 \%$ toe ten opzichte van het meerjaarsgemiddelde, met name door een stijging van het stikstofkunstmestgebruik. Het energiegebruik per hectare cultuurgrond nam ook iets toe. Tussen de jaren fluctueert het energiegebruik onder andere door verschillen in bodemomstandigheden tijdens de teeltwerkzaamheden of de weersomstandigheden waardoor de frequentie van beregening of het uitvoeren van gewasbescherming verschilt. Het aandeel 
bedrijven dat een opvolger heeft en het aandeel bedrijven dat huisverkoop toepast in 2015 , is gelijk aan het meerjaarsgemiddelde (blauwe vlakken in de figuur).

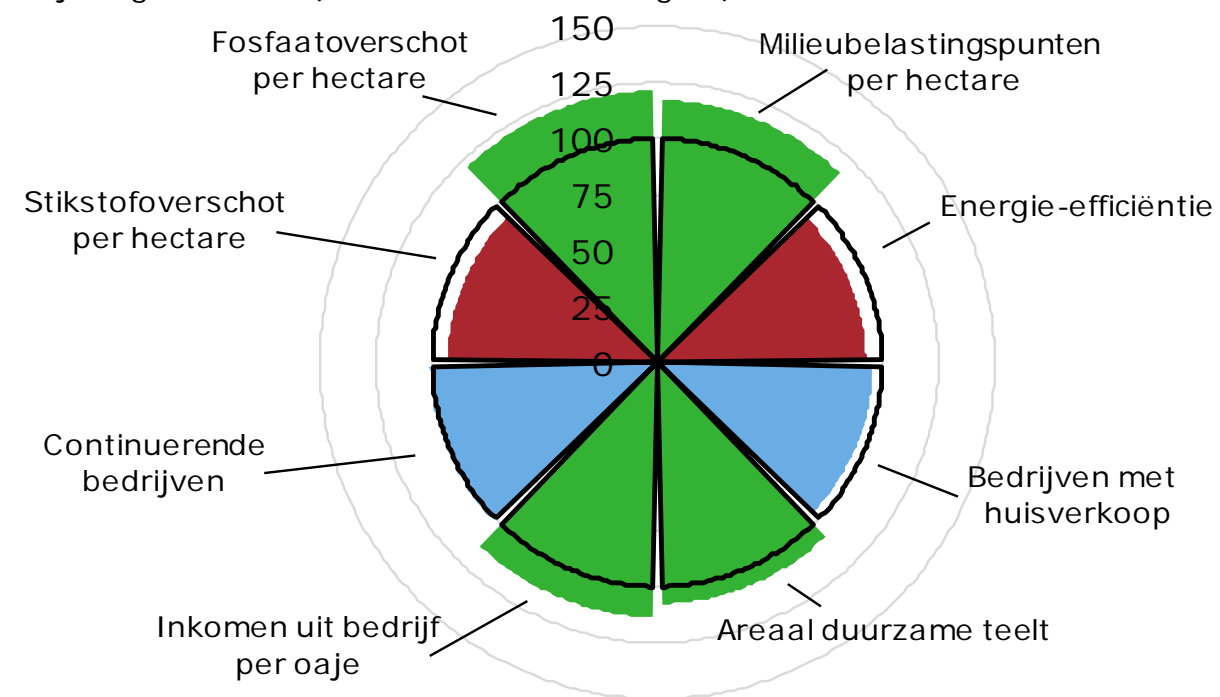

Figuur 6.1 Genormaliseerde relatieve duurzaamheidsprestaties a) in 2015 (vlakken) ten opzichte van het meerjaarsgemiddelde (2010-2015) (dikke lijn) op akkerbouwbedrijven in Zuid-Holland a) Een score van 150 betekent dat de bedrijven in 2015 50\% duurzamer presteren dan het meerjaarsgemiddelde. Het meerjaarsgemiddelde is hierbij op 100 gesteld.

Bron: Wageningen Economic Research.

\section{Duurzaamheidsprestaties in nationaal perspectief}

Wanneer de prestaties van het gemiddelde Zuid-Hollandse akkerbouwbedrijf worden vergeleken met het Nederlandse gemiddelde, zijn er grotere verschillen (figuur 6.2).

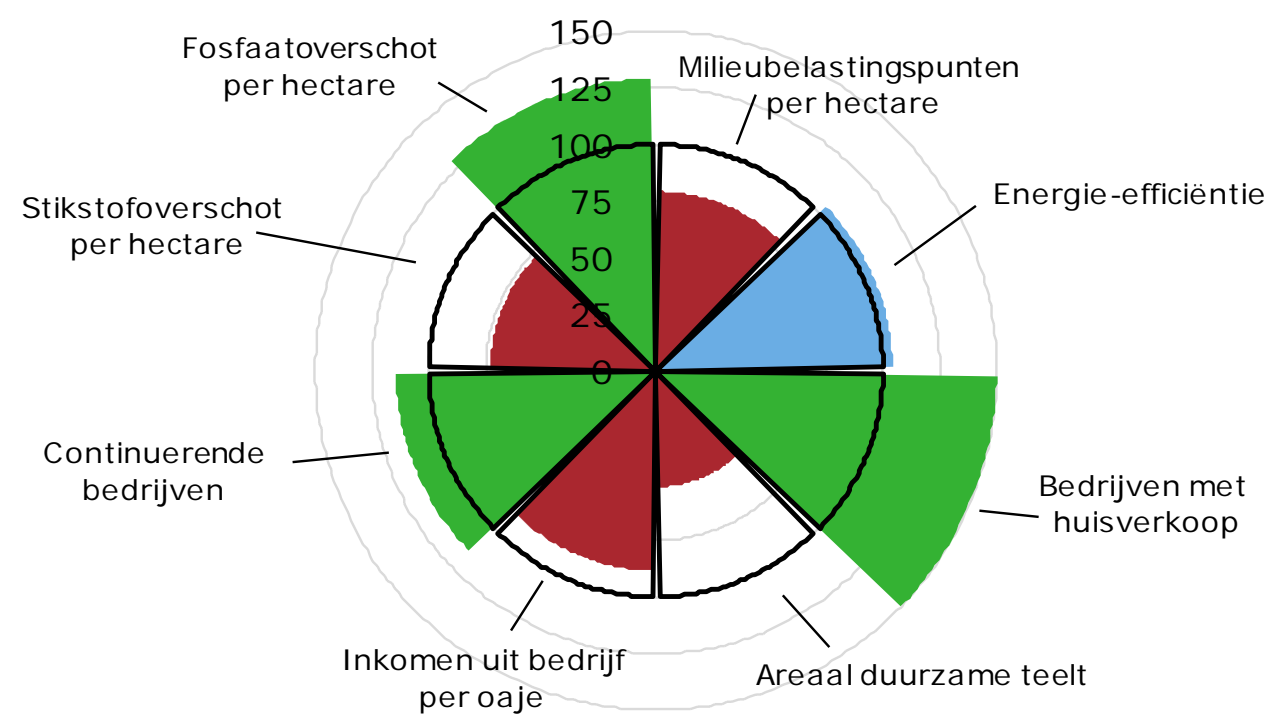

Figuur 6.2 Genormaliseerde relatieve duurzaamheidsprestaties a) van Zuid-Hollandse akkerbouwbedrijven (vlakken) ten opzichte van het Nederlands gemiddelde (dikke lijn) in 2015 a) Een score van 150 betekent dat de bedrijven in 201550 procent duurzamer presteren dan het landelijke gemiddelde. Het landelijke gemiddelde is hierbij op 100 gesteld.

Bron: Wageningen Economic Research.

Op het gebied van milieubelastingspunten per hectare, het stikstofoverschot per hectare cultuurgrond en het inkomen uit bedrijf per onbetaalde arbeidsjaareenheid presteert het gemiddelde 
akkerbouwbedrijf in Zuid-Holland minder goed dan het Nederlandse gemiddelde. Als het gaat om het fosfaatoverschot per hectare, aandeel continuerende bedrijven en het aandeel bedrijven dat huisverkoop toepast, presenteert het Zuid-Hollandse akkerbouwbedrijf beter. Voor de meeste indicatoren geldt dat de bedrijfsopzet vaak verklarend is voor de verschillen. Grondsoort, bouwplan, ligging en bedrijfsomvang hebben vaak een effect op prestaties.

\subsection{Barometer melkveehouderij}

De Barometer duurzame melkveehouderij Zuid-Holland laat zien dat de verschillen in duurzaamheidsprestaties van het jaar 2015 ten opzichte van het meerjaarsgemiddelde (2010-2015) op de meeste indicatoren klein zijn (figuur 6.3). Het gemiddelde melkveebedrijf is in Zuid-Holland beter gaan presteren op het gebied van stikstofoverschot per hectare en energie-efficiëntie. Daar stond tegenover dat het inkomen en het aandeel bedrijven dat huisverkoop toepaste afnam.

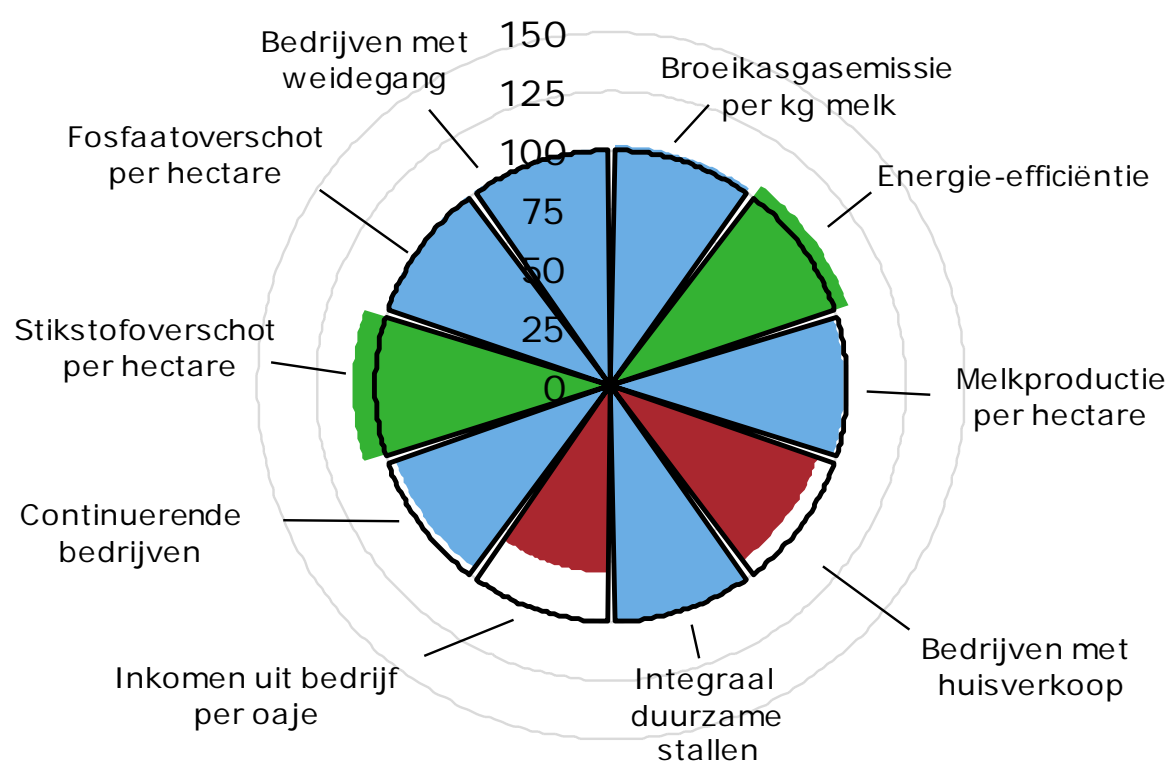

Figuur 6.3 Genormaliseerde relatieve duurzaamheidsprestaties a) van Zuid-Hollandse melkveebedrijven (vlakken) ten opzichte van het Nederlands gemiddelde (dikke lijn) in 2015 a) Een score van 150 betekent dat de bedrijven in 201550 procent duurzamer presteren dan het meerjaarsgemiddelde. Het meerjaarsgemiddelde is hierbij op 100 gesteld.

Bron: Wageningen Economic Research.

Het stikstofoverschot per hectare cultuurgrond op melkveebedrijven in Zuid-Holland nam in 2015 met bijna $10 \%$ af ten opzichte van het meerjaarsgemiddelde. De iets toegenomen melkproductie per hectare voederoppervlakte leidt tot een hogere productie van stikstof en fosfaat in mest per ha. Dit leidde, samen met aanscherpingen in gebruiksnormen, tot een toename in de afvoer van mest en daardoor tot een afname van het zowel het stikstof- als fosfaatoverschot. Het energiegebruik per $\mathrm{kg}$ melk verbeterde in 2015 ten opzichte van het meerjaarsgemiddelde. Het energiegebruik op melkveebedrijven in Zuid-Holland daalde in 2015 voor het vijfde jaar op rij. De daling in energiegebruik per ton melk vond plaats bij zowel het diesel- als elektriciteitsverbruik. Het inkomen uit bedrijf per onbetaalde arbeidsjaareenheid was in 2015 lager dan het meerjaarsgemiddelde. Dit wordt met name veroorzaakt doordat er drie bovengemiddelde tot goede jaren (2011, 2013 en 2014) in het meerjaarsgemiddelde zitten. Daarnaast moet opgemerkt worden dat de inkomensverschillen tussen bedrijven groot zijn.

Het aandeel melkveebedrijven dat huisverkoop toepast, nam iets af. Sinds 2007 neemt het aandeel bedrijven dat huisverkoop toepast af. Een mogelijke verklaring zou de toenemende schaalvergroting en specialisatie kunnen zijn. De overige indicatoren zijn gelijk aan het meerjaarsgemiddelde. 


\section{Duurzaamheidsprestaties in nationaal perspectief}

Wanneer de prestaties van het gemiddelde Zuid-Hollandse melkveebedrijf wordt vergeleken met het Nederlandse gemiddelde, zijn er grotere verschillen. Op zes van de 10 indicatoren geldt dat de ZuidHollandse melkveebedrijven beter presteren dan het Nederlandse gemiddelde (figuur 6.4). Grondsoort, intensiteit, ligging en bedrijfsomvang hebben vaak een effect op prestaties. De melkveehouderij in Zuid-Holland wordt gekenmerkt door een hoog aandeel veengrond, weidegang en extensieve bedrijfsvoering. Daarnaast is het gemiddelde melkveebedrijf in Zuid-Holland kleiner. De intensiteit, melkproductie per hectare en de grondsoort zorgt ervoor dat het gemiddelde ZuidHollandse bedrijf minder goed presteert op broeikasgasemissies en stikstofbodemoverschot. De ZuidHollandse melkveebedrijven hebben een hogere aandeel gras in het rantsoen, hetgeen resulteert in een hogere methaanemissie per kg melk. Lachgasemissie uit de bodem vindt voornamelijk plaats op veengronden. Doordat er in Zuid-Holland relatief veel veengrond aanwezig is, komt de stikstofbodembalans per hectare cultuurgrond ook hoger uit dan het Nederlands gemiddelde. De bodembalans is de bedrijfsbalans inclusief de aanvoer via mineralisatie, depositie en fixatie en de afvoer via gasvormige emissies. Bij veengrond vindt er mineralisatie plaats, waardoor bedrijven op veen een hoger bodemoverschot hebben. De bodembalans valt eveneens hoger uit doordat melkveebedrijven in Zuid-Holland een relatief groot aandeel grasland in het bouwplan. Het hogere aandeel grasland in het bouwplan zorgt eveneens voor een hoger stikstofgebruik. Daar staat tegenover dat het aandeel bedrijven dat weidegang toepast fors hoger is dan het Nederlands gemiddelde. Het aandeel integraal duurzame rundveestallen in Zuid-Holland is lager dan het Nederlands gemiddelde. Er zijn in Zuid-Holland relatief weinig vleesveebedrijven, waar doorgaans een hoger aandeel integraal duurzame stallen is dan op melkveebedrijven. Vleesveebedrijven kunnen een Beter Leven keurmerk krijgen en melkveebedrijven niet.

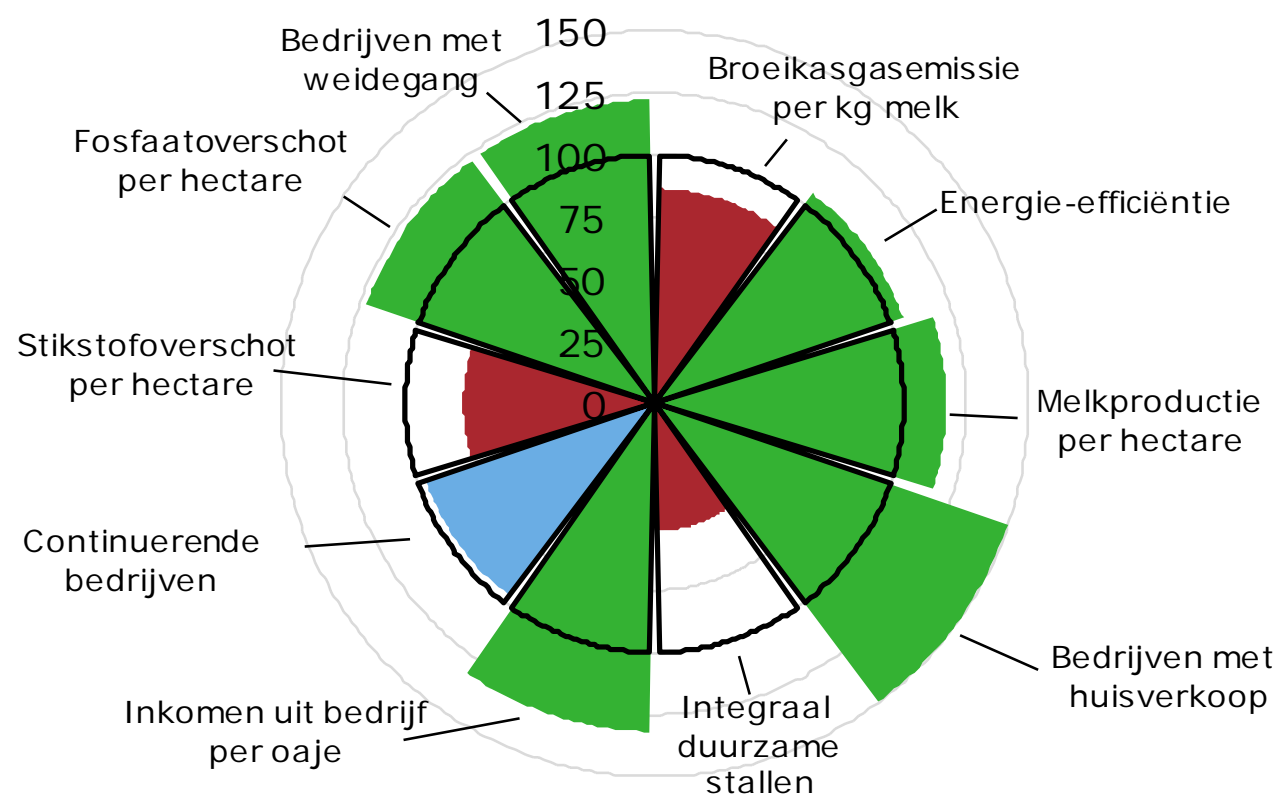

Figuur 6.4 Genormaliseerde relatieve duurzaamheidsprestaties a) van Zuid-Hollandse melkveebedrijven (vlakken) ten opzichte van het Nederlands gemiddelde (dikke lijn) in 2015 a) Een score van 150 betekent dat de bedrijven in 201550 procent duurzamer presteren dan het landelijke gemiddelde. Het landelijke gemiddelde is hierbij op 100 gesteld. Bron: Wageningen Economic Research. 


\section{Literatuur en websites}

Agrimatie.nl, informatie over de agrosector. www.agrimatie. nl

Baltussen, W.H.M., M.A. Dolman, R. Hoste, S.R.M. Janssens, J.W. Reijs en A.B. Smit, 2016.

Grondstofefficiëntie in de zuivel-, varkensvlees-, aardappel- en suikerketen. Wageningen, LEI Wageningen UR (University \& Research centre), LEI Nota 2016-013

Duurzame Zuivelketen 2016. Voortgangsrapportage van het Convenant Weidegang 2016.

http: // www. duurzamezuivelketen. nl/files/Voortgangsrapportage\% 20Convenant\%20Weidegang\% 2020 $16 \% 20$ definitief.pdf

Van der Peet, G.F.V., R.W. van der Meer, H. Docters van Leeuwen en S.R.M. van WageningenLucardie, 2016. Monitoring integraal duurzame stallen; Peildatum 1 januari 2016. Wageningen, Wageningen UR (University \& Research centre) Livestock Research, Livestock Research Rapport 953

GRI, 2017. Global Reporting I nitiative. Reporting principles and disclosures.

https:// www. globalreporting. org/resourcelibrary/GRI G4-Part1-Reporting-Principles-and-Standard-

Disclosures.pdf

Logatcheva, K. en J. van den Puttelaar. Monitor Duurzaam Voedsel 2015. Consumentenbestedingen. LEl factsheet. http://edepot. wur. nl/393682

Maassen et al. 2016 Rapport Veehouderij en gezondheid omwonenden (RIVM).

Reijs, J.W., G.J. Doornewaard, J.H. Jager, M.W. Hoogeveen en A.C.G. Beldman, 2016.

Sectorrapportage Duurzame Zuivelketen; Prestaties 2015 in perspectief. Wageningen, Wageningen Economic Research. http://library. wur. nl/ WebQuery/wurpubs/fulltext/400402

RVO.nl

Van Everdingen, W. (2015) Typering van agrarische bedrijven in Nederland. LEI Wageningen UR Vogelzang, Theo, Bert Smit, Jakob Jager, David Verhoog, Janneke Vader en Jan-Willem van der Schans, 2016. Economische betekenis van de grondgebonden landbouw in Zuid-Holland in 2016. Wageningen, LEI Wageningen UR (University \& Research centre), LEI Report 2016-066

Website emissieregistratie. $\mathrm{nl}$

Website PAS (ministerie EZ)

Website PAS in uitvoering (PAS-bureau) 
Wageningen Economic Research Postbus 29703

2502 LS Den Haag

T 0703358330

E communications.ssg@wur.nl

www.wur.nl/economic-research

Wageningen Economic Research NOTA

2017-052
De missie van Wageningen University \& Research is 'To explore the potential of nature to improve the quality of life'. Binnen Wageningen University \& Research bundelen Wageningen University en gespecialiseerde onderzoeksinstituten van Stichting Wageningen Research hun krachten om bij te dragen aan de oplossing van belangrijke vragen in het domein van gezonde voeding en leefomgeving. Met ongeveer 30 vestigingen, 5.000 medewerkers en 10.000 studenten behoort Wageningen University \& Research wereldwijd tot de aansprekende kennisinstellingen binnen haar domein. De integrale benadering van de vraagstukken en de samenwerking tussen verschillende disciplines vormen het hart van de unieke Wageningen aanpak. 



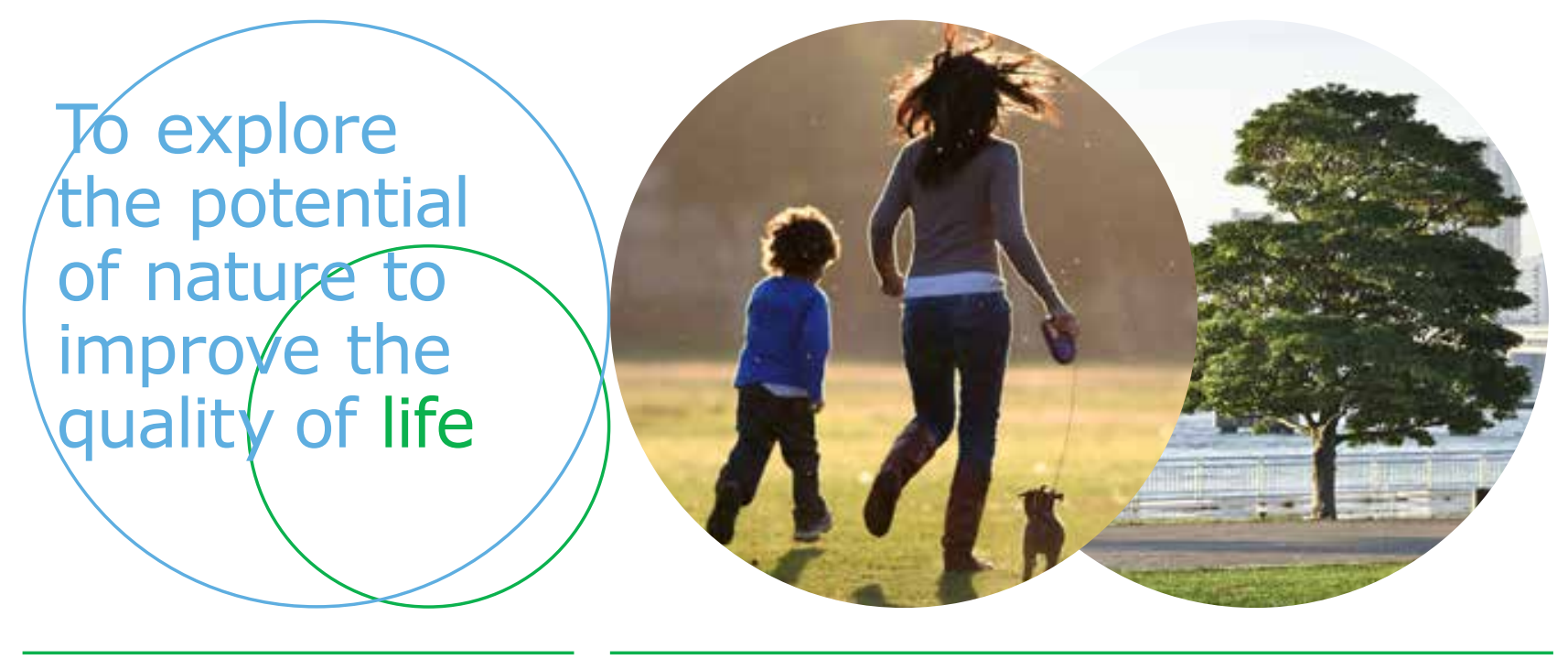

Wageningen Economic Research Postbus 29703

2502 LS Den Haag

E communications.ssg@wur.nl

$\mathrm{T}+31(0) 703358330$

www.wur.nl/economic-research

De missie van Wageningen University \& Research is 'To explore the potential of nature to improve the quality of life'. Binnen Wageningen University \& Research bundelen Wageningen University en gespecialiseerde onderzoeksinstituten van Stichting Wageningen Research hun krachten om bij te dragen aan de oplossing van belangrijke vragen in het domein van gezonde voeding en leefomgeving. Met ongeveer 30 vestigingen, 5.000 medewerkers en 10.000 studenten behoort Wageningen University \& Research wereldwijd tot de aansprekende kennis-

Nota $2017-052$ instellingen binnen haar domein. De integrale benadering van de vraagstukken en de samenwerking tussen verschillende disciplines vormen het hart van de unieke Wageningen aanpak. 